\title{
Validation of water vapour profiles from the Atmospheric Chemistry Experiment (ACE)
}

M. R. Carleer ${ }^{1}$, C. D. Boone ${ }^{2}$, K. A. Walker ${ }^{2,3}$, P. F. Bernath ${ }^{2,4}$, K. Strong ${ }^{3}$, R. J. Sica ${ }^{5}$, C. E. Randall ${ }^{6}$, H. Vömel ${ }^{7}$, J. Kar ${ }^{3}$, M. Höpfner ${ }^{8}$, M. Milz $^{8,}{ }^{*}$, T. von Clarmann ${ }^{8}$, R. Kivi ${ }^{9}$, J. Valverde-Canossa ${ }^{10}$, C. E. Sioris ${ }^{11}$ M. R. M. Izawa ${ }^{12}$, E. Dupuy ${ }^{2}$, C. T. McElroy ${ }^{3,11}$, J. R. Drummond ${ }^{3,13}$, C. R. Nowlan ${ }^{3}$, J. Zou ${ }^{3}$, F. Nichitiu ${ }^{3}$, S. Lossow ${ }^{14}$, J. Urban ${ }^{15}$, D. Murtagh ${ }^{15}$, and D. G. Dufour ${ }^{16}$

${ }^{1}$ Service de Chimie Quantique et Photophysique, Université Libre de Bruxelles, Brussels, Belgium

${ }^{2}$ Department of Chemistry, University of Waterloo, Waterloo, Ontario, Canada

${ }^{3}$ Department of Physics, University of Toronto, Toronto, Ontario, Canada

${ }^{4}$ Department of Chemistry, University of York, UK

${ }^{5}$ Department of Physics and Astronomy, University of Western Ontario, London, Ontario, Canada

${ }^{6}$ Laboratory for Atmospheric and Space Physics, University of Colorado, Boulder, CO, USA

${ }^{7}$ Cooperative Institute for Research in Environmental Sciences, University of Colorado, Boulder, CO, USA

ACE water vapour validation

M. R. Carleer et al.

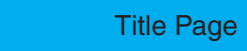

Abstract

Conclusions 
${ }^{8}$ Forschungszentrum Karlsruhe and Universität Karlsruhe, Institut für Meteorologie und Klimaforschung, Karlsruhe, Germany

${ }^{9}$ Finnish Meteorological Institute, Arctic Research Center, Sodankylä, Finland

${ }^{10}$ Universidad Nacional, Heredia, Costa Rica

${ }^{11}$ Environment Canada, Downsview, Ontario, Canada

${ }^{12}$ Department of Earth Sciences, University of Western Ontario, London, Ontario, Canada

${ }^{13}$ Department of Physics \& Atmospheric Science, Dalhousie University, Halifax, Nova Scotia,

Canada

${ }^{14}$ Department of Meteorology, Stockholm University, Stockholm, Sweden

${ }^{15}$ Department of Radio and Space Science, Chalmers University of Technology, Göteborg, Sweden

${ }^{16}$ Picomole Instruments Inc., Edmonton, Alberta, Canada

"now at: Institutionen för Rymdvetenskap, Luleå Tekniska Universitet, Kiruna, Sweden

Received: 4 December 2007 - Accepted: 1 February 2008 - Published: 4 March 2008

Correspondence to: M. R. Carleer (mcarleer@ulb.ac.be)

\section{ACPD}

$8,4499-4559,2008$

ACE water vapour validation

M. R. Carleer et al.

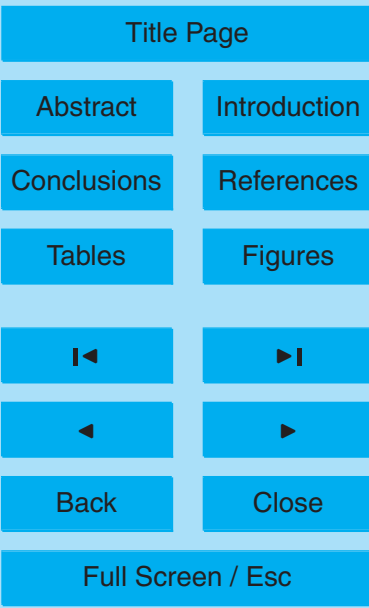

Printer-friendly Version

Interactive Discussion 


\section{Abstract}

The Atmospheric Chemistry Experiment (ACE) mission was launched in August 2003 to sound the atmosphere by solar occultation. Water vapour $\left(\mathrm{H}_{2} \mathrm{O}\right)$, one of the most important molecules for climate and atmospheric chemistry, is one of the key species 5 provided by the two principal instruments, the infrared Fourier Transform Spectrometer (ACE-FTS) and the MAESTRO UV-Visible spectrometer (ACE-MAESTRO). The first instrument performs measurements on several lines in the $1362-2137 \mathrm{~cm}^{-1}$ range, from which vertically resolved $\mathrm{H}_{2} \mathrm{O}$ concentration profiles are retrieved, from 7 to $90 \mathrm{~km}$ altitude. ACE-MAESTRO measures profiles using the water absorption band in the near infrared part of the spectrum at $926.0-969.7 \mathrm{~nm}$. This paper presents a comprehensive validation of the ACE-FTS profiles. We have compared the $\mathrm{H}_{2} \mathrm{O}$ volume mixing ratio profiles with space-borne (SAGE II, HALOE, POAM III, MIPAS, SMR) observations and measurements from balloon-borne frostpoint hygrometers and a ground based lidar. We show that the ACE-FTS measurements provide $\mathrm{H}_{2} \mathrm{O}$ profiles with small

15 retrieval uncertainties in the stratosphere (better than $5 \%$ from 15 to $70 \mathrm{~km}$, gradually increasing above). The situation is unclear in the upper troposphere, due mainly to the high variability of the water vapour volume mixing ratio in this region. A new water vapour data product from the ACE-MAESTRO (Measurement of Aerosol Extinction in the Stratosphere and Troposphere Retrieved by Occultation) is also presented and initial comparisons with ACE-FTS are discussed.

\section{Introduction}

As the most important greenhouse gas, water vapour plays a fundamental role in the climate and chemistry of the Earth's atmosphere. In addition, it is an excellent dynamical tracer in the middle atmosphere. At the Earth's surface, the atmosphere is between 1 and $4 \%$ water vapour. With increasing altitude, the amount of water vapour decreases rapidly in the troposphere. The tropopause acts as a cold trap by freeze-

8, 4499-4559, 2008

ACE water vapour validation

M. R. Carleer et al.

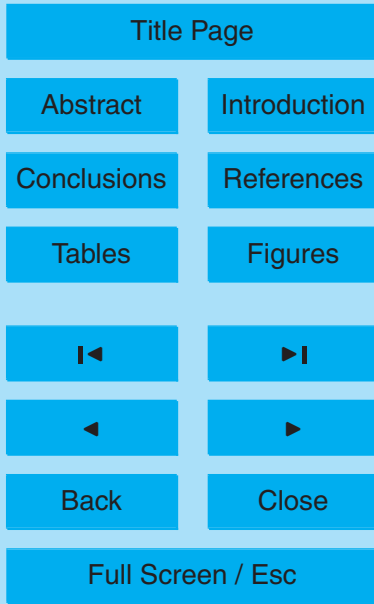

Printer-friendly Version

Interactive Discussion 
drying nearly all water vapour and the consequent sedimentation of the ice particles that are formed.

Water vapour enters the middle atmosphere from the troposphere, mainly through the tropical tropopause transition layer (TTL). This water throughput at the tropical 5 tropopause is around 3.7 ppmv (e.g. Kley et al., 2000) and it exhibits a seasonal variation according to the temperature, which is referred to as the tape recorder effect (Mote et al., 1996). As part of the Brewer-Dobson circulation, air enters the stratosphere in the tropics, then circulates to stratospheric midlatitudes, followed by descent at the poles. This circulation not only transports water, but also energy in the form of 10 heat both vertically and horizontally across the atmosphere. In the stratosphere, water vapour is produced by the oxidation of methane. At the same time, photodissociation and the reaction with $O\left({ }^{1} D\right)$ act as sink processes of water vapour. These processes become even more important in the mesosphere, so that water vapour is increasing in the stratosphere. Around the stratopause, the aforementioned sources and sinks 15 reach an equilibrium state, resulting in the "conventional" water vapour peak.

In the mesosphere, the water vapour concentration generally decreases with altitude due to the lack of additional sources. However, in polar areas in summer and in the tropics around equinox, an additional water vapour peak can be observed between $65 \mathrm{~km}$ and $75 \mathrm{~km}$ (Nedoluha et al., 1996; Summers et al., 1997; Seele and Hartogh, 1999). Sonnemann et al. (2005) explained this peak by an interplay between upwelling winds and autocatalytical water vapour formation from the molecular hydrogen reservoir during the period of strongest solar insolation. Another peak can be observed in a small layer at around $82 \mathrm{~km}$ altitude in the polar summer. This peak is caused by the redistribution of water vapour by ice particles forming polar summer mesosphere echoes and noctilucent clouds (NLCs or polar mesospheric clouds) (Summers et al., 2001; von Zahn and Berger, 2003).

Recent research on the stratospheric water vapour has focused on the tropospherestratosphere exchange (e.g. Sherwood and Dessler, 2000; Kley et al., 2000; Nassar et al., 2005b) and on global trends. Numerous studies have detected an increase in

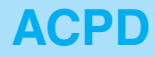

8, 4499-4559, 2008

ACE water vapour validation

M. R. Carleer et al.

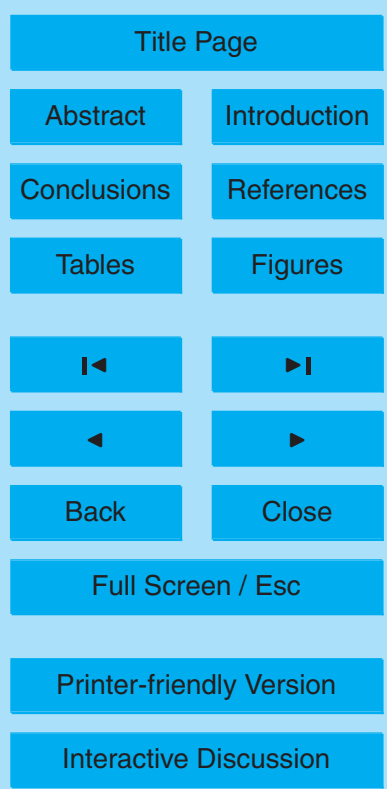

EGU 
stratospheric water vapour occurring over time periods as short as a few years and as long as the past half-century (Oltmans et al., 2000; Michelsen et al., 2000; Rosenlof et al., 2001). More recent evidence indicates that the increase in stratospheric $\mathrm{H}_{2} \mathrm{O}$ has ceased in the last few years and has even shown a temporary decrease on the order of

5 3-4 years (Nedoluha et al., 2003; Randel et al., 2004). Thus understanding changes in stratospheric water vapour and water vapour entering the stratosphere is thus of the greatest importance. The focus of mesospheric research is for the most part on the water vapour budget in the polar summer mesopause region. This covers the amount of water vapour in the presence of NLCs (von Zahn and Berger, 2003), possible trends and inter-hemispheric differences (Hervig and Siskind, 2006).

Satellite-borne instruments have played an important role in furthering our understanding of atmospheric water vapour. Measurements of the vertical distribution of water vapour in the middle atmosphere from space, using limb-observation techniques, began with the launch of the Nimbus-7 satellite in 1979. Two instruments on board this satellite provided measurements of $\mathrm{H}_{2} \mathrm{O}$ : the Stratospheric And Mesospheric Sounder (SAMS) (Drummond et al., 1980; Taylor et al., 1981) and the Limb Infrared Monitor of the Stratosphere (LIMS) (Gille et al., 1980; Fischer et al., 1981). Since the mid-1980s, numerous new instruments have been developed to provide observations of water vapour. Two instruments participated in Space Shuttle missions between 1985 and 1994. The Atmospheric Trace MOlecule Spectroscopy (ATMOS) experiment (Gunson et al., 1996; Abbas et al., 1996) is an infrared Fourier transform spectrometer (FTS) and the Millimeter-wave Atmospheric Sounder (MAS) is a limb-emission radiometer (Hartmann et al., 1996). The second Stratospheric Aerosol and Gas Experiment (SAGE II) (Mauldin et al., 1985; Thomason et al., 2004; Taha et al., 2004) has provided, to date, the longest record of trace gas measurements (including $\mathrm{H}_{2} \mathrm{O}$ ) by a single instrument using solar occultation. They made over two decades of UV-visible observations starting in 1984. In 1991, the launch of the Upper Atmospheric Research Satellite (UARS) (Reber et al., 1993) provided further measurements of water vapour from the HALogen Occultation Experiment (HALOE) (Russell et al., 1993; Harries, 1996; Nedoluha et al.,

ACE water vapour validation

M. R. Carleer et al.

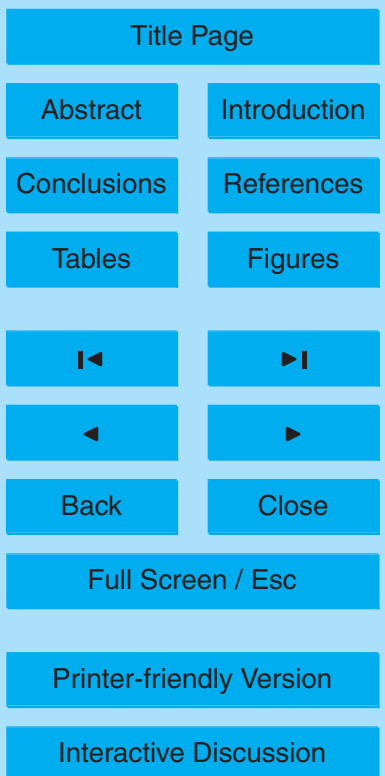

EGU 
1997, 2003), the Improved Stratospheric And Mesospheric Sounder (ISAMS) (Taylor et al., 1993; Goss-Custard et al., 1996) and the Microwave Limb Sounder (MLS) (Barath et al., 1993; Pumphrey et al., 2000). The list of instruments providing or having provided $\mathrm{H}_{2} \mathrm{O}$ measurements was expanded more recently with the CRyogenic Infrared

5 Spectrometers and Telescopes for the Atmosphere (CRISTA) instrument on the Space Shuttle (Offermann et al., 1999, 2002) and by several satellite-borne solar occultation instruments: the Polar Ozone and Aerosol Measurement (POAM) III instrument (Lucke et al., 1999; Nedoluha et al., 2003; Lumpe et al., 2006) and the two successive Improved Limb Atmospheric Sounder (ILAS) instruments ILAS-I (Nakajima et al., 2002; 10 Kanzawa et al., 2002) and ILAS-II (e.g. Nakajima et al., 2006; Griesfeller et al., 2008).

Currently, there are four satellite missions providing vertical profiles of water vapour from limb measurements. The Sub-Millimeter Radiometer (SMR) onboard Odin (Murtagh et al., 2002; Urban et al., 2007; Lossow et al., 2007), the Michelson Interferometer for Passive Atmospheric Sounding (MIPAS) on Envisat (Fischer et al., 2007, 15 and references therein) and the second-generation MLS on the Aura satellite (e.g., Waters et al., 1999; Santee et al., 2005) all use limb-emission techniques. The Atmospheric Chemistry Experiment (ACE) placed onboard SCISAT provides $\mathrm{H}_{2} \mathrm{O}$ from solar occultation observations (Bernath et al., 2005).

ACE, the first of a planned series of small Canadian scientific satellites, was 20 launched into low Earth circular orbit (altitude $650 \mathrm{~km}$, inclination $74^{\circ}$ ) on 12 August 2003. Following a 6-month commissioning period, the ACE instruments science operations started on 21 February 2004. The two principal instruments are the infrared ACE-FTS (Bernath et al., 2005) and the ACE-MAESTRO (Measurement of Aerosol Extinction in the Stratosphere and Troposphere Retrieved by Occultation; McElroy et al., 2007) UV-Visible spectrometer. These two sensors make simultaneous occultation measurements using a shared sun-tracking mirror located in the ACE-FTS. Water vapour volume mixing ratio (VMR) profiles are part of the baseline dataset for the ACEFTS and are a new product for the ACE-MAESTRO.

In order to validate the water vapour results obtained from the ACE-FTS, we

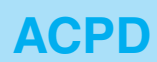

$8,4499-4559,2008$

ACE water vapour validation

M. R. Carleer et al.

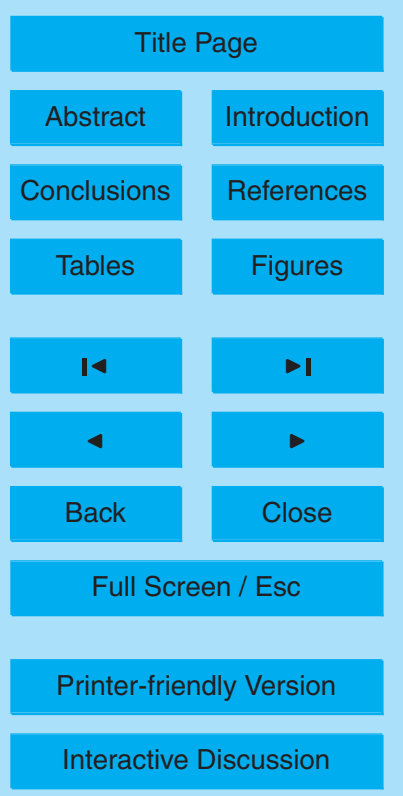


have compared them to several measurements made with various instruments either ground-based, balloon- or space-borne. The correlative instruments use various remote sensing technologies including spectrometers and lidars as well as in situ humidity sensors. The results of these comparisons are given in the following chapters,

5 together with a brief description of each correlative instrument. Due to the high spatial and temporal variability of the water vapour concentration in the troposphere, most of the comparisons are done statistically, using the mean value of many measurements falling within a certain time span and a certain area of coincidence between the retrieved profiles. In addition, we present a new ACE-MAESTRO $\mathrm{H}_{2} \mathrm{O}$ VMR product and discuss initial comparisons with the ACE-FTS results.

\section{ACE instruments and retrievals}

The principal instrument onboard SCISAT is a high resolution FTS named ACE-FTS with the following main specifications: spectra recorded from $750 \mathrm{~cm}^{-1}$ to $4400 \mathrm{~cm}^{-1}$ $(13.3$ to $2.2 \mu \mathrm{m})$, at a resolution of $0.02 \mathrm{~cm}^{-1}( \pm 25 \mathrm{~cm}$ maximum optical path differ15 ence). The instrument works in the solar occultation mode and records one full spectrum in about $2 \mathrm{~s}$ with a signal-to-noise ratio between 300:1 and 400:1 near the center of the wavenumber range. The delay between consecutive spectra gives a vertical spacing varying from 1.5 to $6 \mathrm{~km}$ depending on the angle between the orbital direction and the viewing direction with a maximum altitude resolution of $3-4 \mathrm{~km}$ due to the field of view of the instrument $(1.25 \mathrm{mrad})$. The details of ACE-FTS spectra inversions are described in Boone et al. (2005). Currently, VMR profiles of more than thirty different trace gases are retrieved from the ACE-FTS spectra. The $\mathrm{H}_{2} \mathrm{O}$ retrieval utilizes $60 \mathrm{mi}-$ crowindows, which fall in the $950-975 \mathrm{~cm}^{-1}$ and $1360-2000 \mathrm{~cm}^{-1}$ regions to retrieve profiles from 5 to $90 \mathrm{~km}$ altitude. The current version of the ACE-FTS data products is 2.22 including updates for ozone, $\mathrm{HDO}$ and $\mathrm{N}_{2} \mathrm{O}_{5}$.

ACE-MAESTRO, the second instrument aboard SCISAT is a dual-channel optical spectrometer operating in the spectral region between 285 and $1030 \mathrm{~nm}$. Solar oc-

ACE water vapour validation

M. R. Carleer et al.

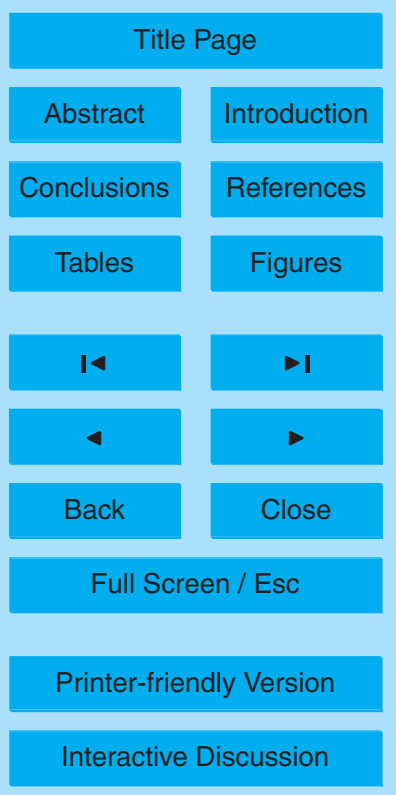


cultation spectra are being used to retrieve vertical profiles of temperature and pressure, aerosols, and trace gases $\left(\mathrm{O}_{3}, \mathrm{NO}_{2}, \mathrm{H}_{2} \mathrm{O}\right.$, and $\left.\mathrm{OCIO}\right)$ involved in the stratospheric ozone chemistry. The use of two overlapping spectrometers $(280-550 \mathrm{~nm}$, $500-1030 \mathrm{~nm}$ ) improves the stray-light performance. The spectral resolution is about

$52 \mathrm{~nm}$ in the near-infrared. The vertical resolution is estimated to be better than $1.7 \mathrm{~km}$ (McElroy et al., 2007).

The algorithm to retrieve water vapour profiles uses the observed wavelengthintegrated differential optical depth (DOD) over 926.0-969.7 $\mathrm{nm}$ range. The optical depth baseline is removed by subtracting a slope term interpolated from end points of

10 this fitting window. The absorption optical depth due to water vapour and ozone are simulated with a correlated-k band model (Berk et al., 1999). The water vapour VMR profile in the atmosphere of this forward model is updated with Chahine's relaxation technique (Chahine, 1970) to match the observed wavelength-integrated DOD at each measured tangent height. The ozone absorption optical depth is small and is assumed 15 to be known a priori. Current processing version of the spectra is 1.0 . It must be pointed out that the data presented here are preliminary and are not part of the highpriority ACE-MAESTRO products. Water vapour profiles are only currently available from August to October 2005.

\section{ACE-FTS validation}

\section{$20 \quad 3.1$ Satellites}

\subsubsection{SAGE II}

The SAGE II (Stratospheric Aerosol and Gas Experiment II) sensor was launched into a 57 degree inclination orbit at $610 \mathrm{~km}$ aboard the Earth Radiation Budget Satellite (ERBS) in October 1984 (Mauldin et al., 1985). The instrument ceased operations in

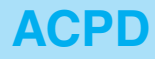

8, 4499-4559, 2008

ACE water vapour validation

M. R. Carleer et al.

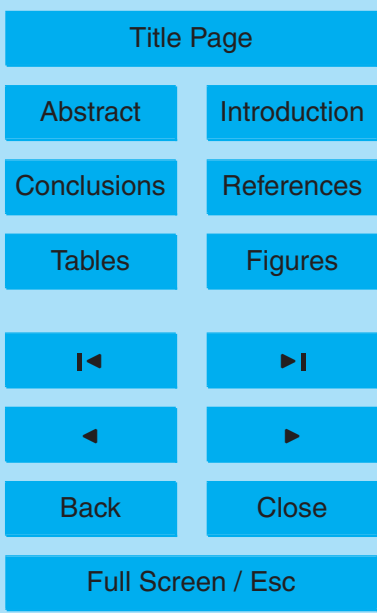

Printer-friendly Version

Interactive Discussion 
During each sunrise and sunset encountered by the orbiting spacecraft, the instrument used the solar occultation technique to measure attenuated solar radiation through the Earth's limb in seven channels centered at wavelengths ranging from 0.385 to 1.02 micrometers. Profiles of $\mathrm{H}_{2} \mathrm{O}, \mathrm{O}_{3}, \mathrm{NO}_{2}$, and aerosol extinction were produced from 5 these measurements.

Water vapour is retrieved using the $935 \mathrm{~nm}$ channel (Chu et al., 1993). SAGE II water vapour retrievals have undergone several revisions over the years. These retrievals indicated strong influence of aerosol contamination and anomalies near the hygropause region with a dry bias of up to $\sim 40 \%$ in version 6.0 (Chu et al., 1993, 1993; Michelsen 10 et al., 2002). Several important modifications were incorporated in a new product (version 6.2) which was released in October 2003, with significantly reduced sensitivity to aerosols (Thomason et al., 2004; Chiou et al., 2004). Version 6.2 retrievals have been extensively compared with ballonborne and satellite measurements and were found to agree within $\sim 10-15 \%$ between $15-40 \mathrm{~km}$ with a high bias and decreasing precision 15 above $40 \mathrm{~km}$ (Taha et al., 2004).

The SAGE II version 6.2 and ACE-FTS data sets were searched for all occultations that occurred within $\pm 2 \mathrm{~h}$ and $500 \mathrm{~km}$. A total of 169 coincidences were found during the time both instruments collected spectra. Initially, comparisons were made separately for sunrise/sunrise and sunset/sunset combinations and we also separated the comparisons between coincidences in 2004 and 2005. In both cases results were very similar, so only the overall combined results are shown here. Mean mixing ratio profiles for all coincidences are shown in Fig. 1. Both instruments show VMRs gradually increasing with altitude above about $15 \mathrm{~km}$, and sharply increasing below $15 \mathrm{~km}$. Note also that the variability in the SAGE II measurements is significantly higher than in the ACE-FTS measurements.

Figure 2 shows the profiles of the standard deviations of the distributions in percent relative to the mean VMR at each altitude. ACE-FTS variations are on the order of $15 \%$ or less above $15 \mathrm{~km}$; SAGE II variations are around $15-20 \%$ from $15-40 \mathrm{~km}$, but increase at higher altitudes in agreement with the conclusions of Taha et al. (2004).

ACE water vapour validation

M. R. Carleer et al.

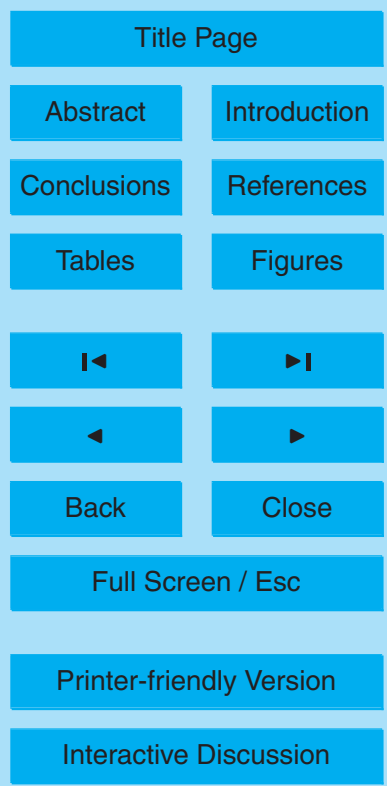

EGU 
The differences between ACE-FTS and SAGE II are quantified in Fig. 3. The differences between ACE-FTS and SAGE II become more negative with increasing altitude, from about $+20 \%$ at $10 \mathrm{~km}$ down to $-20 \%$ near $50 \mathrm{~km}$. The reason for this is not understood, but we note that the difference profile is similar in character to that obtained for 5 POAM III - SAGE II by Lumpe et al. (2006). However, using only SAGE II data with an error $<50 \%$ as recommended by Taha et al. (2004) tends to remove the low values at the higher altitudes thus possibly giving a high bias to the SAGE II mean value. Below $20 \mathrm{~km}$, some of the difference might be attributed to the aerosol clearing problems in SAGE II data.

\subsubsection{HALOE}

The HALogen Occultation Experiment (HALOE) was launched on the Upper Atmosphere Research Satellite (UARS) spacecraft in September 1991, and after a period of outgassing, it began science observations in October 1991 (Russell et al., 1993). The experiment uses solar occultation to measure vertical profiles of $\mathrm{O}_{3}, \mathrm{HCl}, \mathrm{HF}, \mathrm{CH}_{4}$, $15 \mathrm{H}_{2} \mathrm{O}, \mathrm{NO}, \mathrm{NO}_{2}$, aerosol extinction at 4 infrared wavelenths, and temperature versus pressure with an instantaneous vertical field of view of $1.6 \mathrm{~km}$ at the Earth's limb. Latitudinal coverage is from $80^{\circ} \mathrm{S}$ to $80^{\circ} \mathrm{N}$ over the course of 1 year and includes extensive observations of the Antarctic region during spring. The altitude range of the measurements extends from about $15 \mathrm{~km}$ to $60-130 \mathrm{~km}$, depending on the species. HALOE collected its final occultation event in November 2005.

HALOE water vapour retrievals have been compared extensively to in situ and remote measurements, as summarized by Harries et al. (1996) and the SPARC water vapour report (Kley et al., 2000). These comparisons suggest that $\mathrm{HALOE} \mathrm{H}_{2} \mathrm{O}$ is biased low by about $5 \%$ in the stratosphere.

25 The HALOE version 19 and ACE-FTS data sets were searched for coincident measurements, also defined as occurring within $\pm 2 \mathrm{~h}$ in time and $500 \mathrm{~km}$ distance. A total of 36 coincidences were found during the time both instruments made measurements. Note that most comparisons correspond to polar summer conditions in the Northern 4508

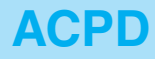

$8,4499-4559,2008$

ACE water vapour validation

M. R. Carleer et al.

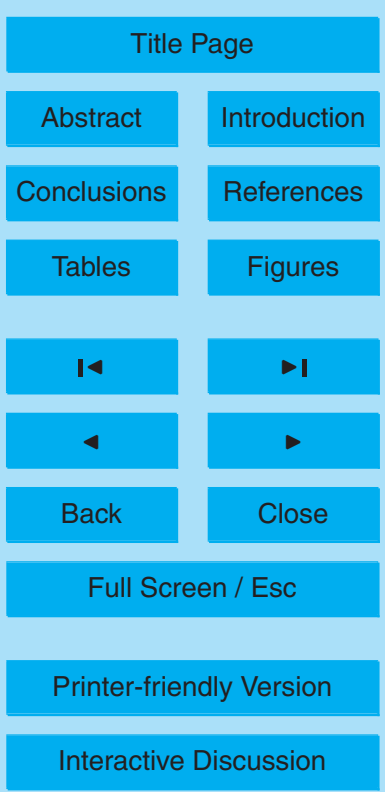


Hemisphere. Figure 4 shows the average $\mathrm{H}_{2} \mathrm{O}$ profiles measured by both instruments for all coincidences. Although the analysis was performed separately for sunrise and sunset occultations, there were too few sunrise coincidences to obtain statistically significant results. Thus, only results for averages over all of the coincidences are reported 5 here. Both instruments show very similar profile shapes, with VMRs increasing above about $15 \mathrm{~km}$. The altitude of the hygropause is the same in both instruments, although VMRs increase much more rapidly below this altitude in the ACE-FTS than in HALOE, resulting in significantly larger ACE-FTS VMRs below $15 \mathrm{~km}$. At higher altitudes the ACE-FTS VMRs are also larger than HALOE, but by a smaller amount.

10 Qualitatively, both measurements have similar variability from about $15-40 \mathrm{~km}$, with HALOE variability increasing at higher altitudes. Measurement variability is quantified in Fig. 5, which shows the standard deviations of the distributions relative to the mean VMRs. There is excellent agreement between ACE-FTS and HALOE from about 15$40 \mathrm{~km}$, with standard deviations on the order of $5 \%$. As expected from Fig. 4, variability 15 in the HALOE measurements is more than twice as large as that for ACE-FTS near $50 \mathrm{~km}$. There is a significant increase in variability near $30 \mathrm{~km}$ that is captured by both instruments, suggesting that this is a real phenomenon. This is also seen in HALOE comparisons with other constituents such as $\mathrm{CH}_{4}$ and HF (see DeMaziere et al., 2007; Mahieu et al., 2008). We believe that this reflects real summertime longitudinal variations arising from differential meridional transport caused by breaking of westwardpropagating waves that are evanescent in the summer easterly flow (see Hoppel et al., 1999).

Figure 6 shows the percent differences between the instruments, plotted as ACEFTS minus HALOE relative to the average of the two instruments. As noted above, 25 measurements from the ACE-FTS are biased high compared to HALOE, but only by about $5 \%$ from $20-50 \mathrm{~km}$. Given the possible low bias in HALOE data, this suggests that the ACE-FTS measurements are highly accurate in this altitude range. There is a significant high bias below $17 \mathrm{~km}$, increasing to more than $40 \%$ below $13 \mathrm{~km}$. This reflects the difference in slope of the VMRs below the hygropause. At this point it is

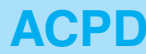

$8,4499-4559,2008$

ACE water vapour validation

M. R. Carleer et al.

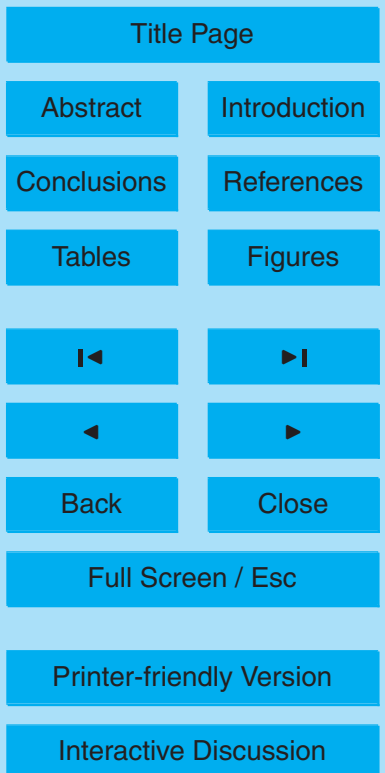

EGU 
not clear if this is indicative of an error in one or both instruments, or if it is simply an indication that the geophysical conditions sampled by ACE-FTS were different from the geophysical conditions sampled by HALOE in this highly variable region of the atmosphere. It could also be due to the coarser vertical resolution of the ACE-FTS.

\section{3.1.3 POAM III}

The Polar Ozone and Aerosol Measurement III (POAM III) instrument was developed by the Naval Research Laboratory (NRL) to measure the vertical distribution of atmospheric $\mathrm{O}_{3}, \mathrm{H}_{2} \mathrm{O}, \mathrm{NO}_{2}$, aerosol extinction, and temperature (Lucke et al., 1999). POAM III measured solar extinction in nine narrow band channels, covering the spectral range from approximately 350 to $1060 \mathrm{~nm}$. POAM III was carried by the SPOT-4 spacecraft sponsored by the Centre National d'Etudes Spatiales (CNES), the French Space Agency. It was launched in March 1998 in polar orbit and ceased operation in December 2005.

Lumpe et al. (2006) performed comparisons between POAM III, HALOE and SAGE

II measurements. They concluded that POAM III version 4.0 had a $5-10 \%$ high bias for sunrise measurements in the stratosphere below $35 \mathrm{~km}$, transitioning to a possible low bias of $10 \%$ by $50 \mathrm{~km}$. POAM III sunset measurements are $5-10 \%$ higher than sunrise measurements.

Once again the chosen coincidence criteria are within $\pm 2 \mathrm{~h}$ and $500 \mathrm{~km}$ distance.

With POAM III version 4.0, we detected 316 coincidences. Figures 7-9 are analogous to Figs. 1-3 and 4-6. Like the HALOE and SAGE II comparisons, the instruments show similar profile shapes. As shown in Fig. 7, ACE-FTS reports less water than POAM III throughout most of the altitude range, consistent with the high POAM bias described by Lumpe et al. (2006). Note also the large variability in the POAM measurements compared to ACE-FTS. This is quantified in Fig. 8, which shows FTS variations around $5-10 \%$ throughout most of the altitude range, whereas POAM variability ranges from about $15-30 \%$. The relatively low precision of the POAM $\mathrm{H}_{2} \mathrm{O}$ measurements was explained by Lumpe et al. (2006). Figure 9 quantifies the differences between ACE-

ACE water vapour validation

M. R. Carleer et al.

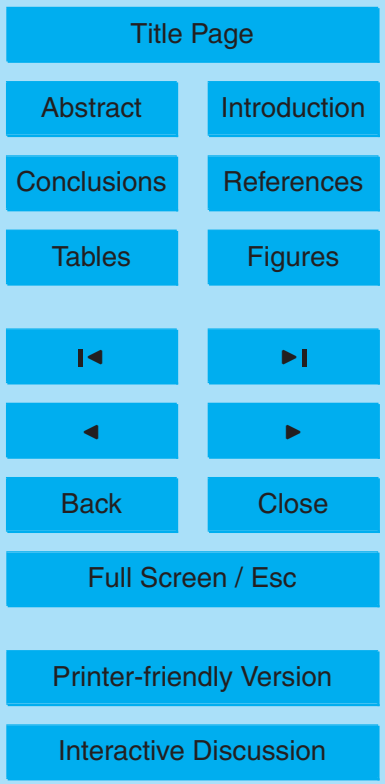


FTS and POAM III. ACE-FTS VMRs are lower than those measured by POAM III from about $13-40 \mathrm{~km}$, with a maximum difference of $\sim 18 \%$ near $20 \mathrm{~km}$. Differences are positive above $40 \mathrm{~km}$. Taking into account the conclusions of Lumpe et al. (2006) about POAM III biases, the ACE-FTS profiles seem in very good agreement with corrected 5 POAM III profiles. Below $13 \mathrm{~km}$ the differences are again positive, showing the same bias as SAGE II and HALOE. That all three solar occultation instrument comparisons show positive differences near $10 \mathrm{~km}$ possibly suggests a real wet bias in the ACEFTS data at this altitude. Note, however, that variability in $\mathrm{H}_{2} \mathrm{O}$ increases substantially near the tropopause, so it is also possible that geophysical variations contribute to 10 the differences. In Fig. 7 there is a noticeable difference between the ACE-FTS and POAM III mean profiles around $20-25 \mathrm{~km}$, with the ACE-FTS showing only a hint of the strong maximum seen in the POAM III profile. This could be because of the lower vertical resolution of ACE-FTS as compared to POAM III, although a similar maximum was seen quite clearly in the comparison with the SAGE II profiles.

\subsubsection{MIPAS}

The Michelson Interferometer for Passive Atmospheric Sounding (MIPAS) is one of the core experiments on ESA's Envisat satellite, launched in March 2002 (Fischer et al., 2007). Envisat is in a quasi-polar, sun-synchronous orbit at an altitude of $800 \mathrm{~km}$ which provides pole to pole coverage each day. MIPAS measures atmospheric limb emission 20 spectra from $685-2410 \mathrm{~cm}^{-1}(14.5$ to $4.1 \mu \mathrm{m})$ over a tangent altitude range $6-68 \mathrm{~km}$. After suitable ground processing, these spectra allow quantification of concentration profiles of numerous atmospheric trace species. In addition, atmospheric temperature as well as the distribution of aerosol particles, tropospheric cirrus, and stratospheric ice clouds can also be derived from MIPAS data (Fischer et al., 2007).

25 Vertical profiles of $\mathrm{H}_{2} \mathrm{O}$ from MIPAS chosen for these comparisons have been retrieved with the dedicated scientific IMK-IAA data processor (von Clarmann et al., 2003). The basic retrieval strategy for water vapour has been described by Milz et al. (2005). For the actual comparison with ACE-FTS we have used the most recent

ACE water vapour validation

M. R. Carleer et al.

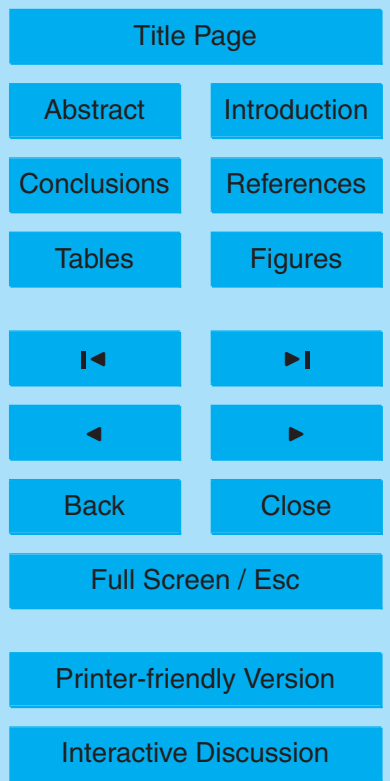

EGU 
version 13 IMK-IAA $\mathrm{H}_{2} \mathrm{O}$ dataset which differs from the version described by Milz et al. (2005) with respect to the following two items: (1) log(VMR) instead of VMR has been used as the primary retrieval quantity. This allows the usage of an altitude constant a priori $\mathrm{H}_{2} \mathrm{O}$ profile independent of latitude. (2) $\mathrm{NO}_{2}$ has been added as a second

5 fit parameter. Especially for the location and time of these comparisons, modification (2) has been important to account for interfering $\mathrm{NO}_{2}$ lines which were strongly enhanced during night at high altitudes due to an enhanced downward transport of $\mathrm{NO}_{\mathrm{x}}$ inside the polar vortex.

Coincidences between MIPAS and ACE-FTS are found in the period from 10 Febru10 ary until 26 March 2004 located between $30^{\circ} \mathrm{N}$ and $80^{\circ} \mathrm{N}$. (It should be noted that the measurements before 21 February 2004 were taken during the commissioning phase of the ACE mission.) The following coincidence criteria have been applied: maximum time difference of $\pm 9 \mathrm{~h}$, maximum location difference of $800 \mathrm{~km}$, and maximum difference of potential vorticity of $3 \times 10^{-6} \mathrm{~km}^{2} \mathrm{~kg}^{-1} \mathrm{~s}^{-1}$ at an altitude of $475 \mathrm{~K}$ potential 15 temperature. Over all co-incidences, this resulted in a mean distance of $300 \pm 150 \mathrm{~km}$ and a mean time difference of $0.2 \mathrm{~h}$ (ACE-FTS - MIPAS). The distribution of the time differences is, however, bi-modal since MIPAS measurements at the latitudes of the MIPAS/ACE-FTS coincidences are either at day or night while the ACE-FTS observations used here are made during sunset. Thus, for nighttime MIPAS observations, the time difference (ACE-FTS - MIPAS) is $-5 \pm 1.3 \mathrm{~h}$, while in the case of MIPAS daytime measurements it is $5.7 \pm 1.6 \mathrm{~h}$.

Figure 10 presents the mean value of the VMR of 381 ACE-FTS profiles compared to 728 MIPAS profiles. The black curve shows the ACE-FTS and the red curve the MIPAS mean profile.

Figure 11 shows the profiles of the standard deviations of the distributions as percent relative to the mean VMR at each altitude. ACE-FTS variations are on the order of $5-13 \%$ at $15-45 \mathrm{~km}$. MIPAS standard deviations are comparable to ACE-FTS below $20 \mathrm{~km}$. From $25-40 \mathrm{~km}$, they increase to values around $15 \%$ which is about $10 \%$ higher than the ACE-FTS variability at these altitudes. This is due to a concurrent increase of

ACE water vapour validation

M. R. Carleer et al.

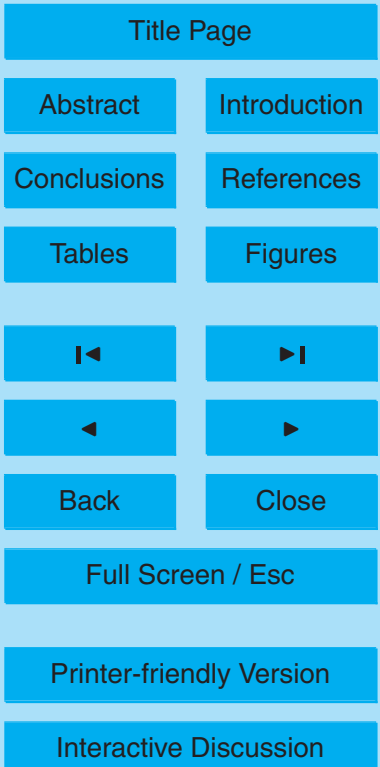


MIPAS estimated noise errors at these altitudes. Above $45 \mathrm{~km}$, MIPAS and ACE-FTS variability increase due to a combination of increase of spectral noise error and the strong geophysical variability during the coincidence period.

Figure 12 shows the difference in percent between ACE-FTS and MIPAS. One can 5 see that the differences, from 68 down to $14 \mathrm{~km}$ never exceed $8 \%$. Within that altitude range the mean bias of ACE-FTS with respect to MIPAS is $+3.2 \%$.

Below $14 \mathrm{~km}$, however, the two sets diverge and mainly below the hygropause the ACE-FTS values are up to $20 \%$ higher than MIPAS.

\subsubsection{Odin-SMR}

10 Odin was developed by the Swedish Space Corporation, but it is an international project where the space agencies of Finland (TEKES), Canada (CSA) and France (CNES) are involved. It was launched in February 2001 into a circular, sun-synchronous, quasipolar orbit at $600 \mathrm{~km}$ altitude (Murtagh et al., 2002). One of the two instruments onboard Odin is an advanced Sub-Millimeter Radiometer (SMR) using a $1.1 \mathrm{~m}$ telescope, which is used for both astronomy and aeronomy missions (Frisk et al., 2003). It measures thermal emission lines at the Earth's limb in the frequency band $486-580 \mathrm{GHz}$, covering several water vapor lines (Urban et al., 2007). Mesospheric water vapor is retrieved from the $557 \mathrm{GHz}$ line and the current retrieval version 2.1 is described by Lossow et al. (2007).

20 We found 2033 coincidences within $\pm 5 \mathrm{~h}$ and less than $1000 \mathrm{~km}$ apart between the measurements taken by the Odin-SMR and the ACE-FTS in the mesosphere. We separated the coincidences by latitude as well by three-month season. Even if the profiles were largely different the results of the comparisons were very similar. The average ACE-FTS and SMR profiles for all coincidences are shown in Fig. 13 in the altitude range from 50 to $90 \mathrm{~km}$. The black line is the ACE-FTS average profile and the red one the Odin-SMR average profile. One can see that the ACE-FTS profile is larger than the SMR for all altitudes. Both profiles show a marked decrease in water VMR with altitude. Figure 14 shows the difference (ACE-FTS - Odin-SMR) between

ACE water vapour validation

M. R. Carleer et al.

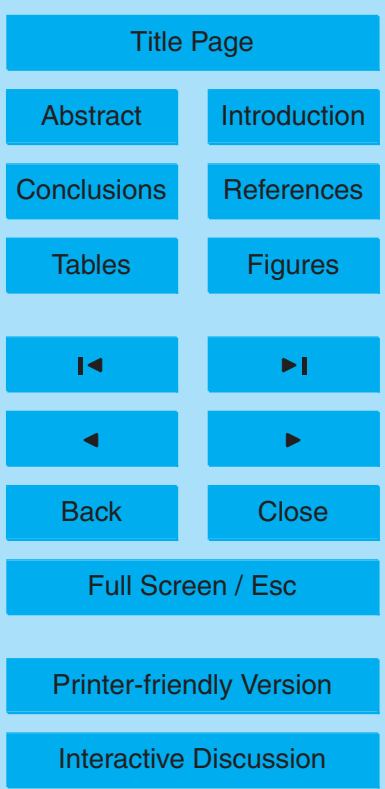


the two profiles in VMR units. The bias is almost constant at a value of around 0.4 ppmv over the entire altitude range. However some remaining calibration issues in the Odin-SMR data are probably responsible for this discrepancy (S. Lossow, personal communication).

$5 \quad$ Figure 15 presents the same difference this time in percent with respect to the mean of the ACE-FTS and SMR VMRs. The difference from 50 up to $82 \mathrm{~km}$ does not exceed $10 \%$, but increases sharply above $82 \mathrm{~km}$ when the VMR approaches zero ppmv.

Gattinger et al. (2006) compared Odin-OSIRIS mesospheric $\mathrm{OH}$ observations with $\mathrm{OH}$ deduced from a photochemical model applied to ACE-FTS $\mathrm{H}_{2} \mathrm{O}$ measurements.

10 They not only find a very good agreement between the two, but also that longitudinal and temporal variabilities are well reproduced.

\subsubsection{Aura-MLS}

The Aura Microwave Limb Sounder (MLS), an advanced successor to the MLS instrument on the Upper Atmosphere Research Satellite (UARS), is a limb sounding instrument which measures thermal emission at millimeter and sub-millimeter wavelengths using seven radiometers to cover five broad spectral regions (Waters et al., 1999). The standard $\mathrm{H}_{2} \mathrm{O}$ product is retrieved from the radiances measured by the radiometers centered near $190 \mathrm{GHz}$. The water retrievals from this instrument were already compared to the ACE-FTS version 2.2 data (Lambert et al., 2007). The authors come to the conclusion that both sets agree to better than $\pm 5 \%$ with no offset from 15 to $40 \mathrm{~km}$. At lower altitudes, they also see a sharp wet bias of the ACE-FTS measurements, just as we do with the other satellite instruments.

\subsection{Frostpoint hygrometers}

The Cryogenic Frostpoint Hygrometer (CFH), which is currently built at the University of Colorado, is capable of measuring the large range of water vapour concentrations found in the troposphere and stratosphere (Vömel et al., 2007). It is carried up by small

\section{ACPD}

$8,4499-4559,2008$

ACE water vapour validation

M. R. Carleer et al.

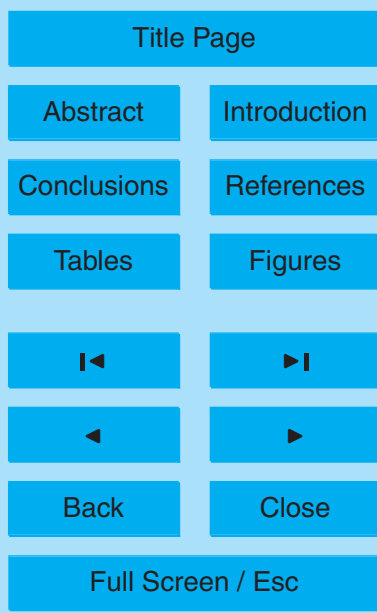

Printer-friendly Version

Interactive Discussion 
meteorological balloons and measures a water vapour profiles between the surface and the middle stratosphere with high vertical resolution. The VMR uncertainty is about $4 \%$ in the lower tropical troposphere to about $10 \%$ in the middle stratosphere and tropical tropopause. Balloons were launched from 2004 to 2007 from Boulder in Colorado, San 5 Jose in Costa Rica and Sodankylä in Finland. At Boulder, CO some soundings were obtained using the older NOAA/ESRL (National Oceanic and Atmospheric Administration/ Earth System Research Laboratory) FrostPoint hygrometer (FP). The spatial coincidence criteria were latitude differences less than \pm 5 degrees and longitude less than \pm 20 degrees. The profiles were separated into 2 month periods and selected 10 comparisons are shown in Figs. 16 to 20. In these figures, all profiles are shown for the indicated period, the FP/CFH in red and the ACE-FTS in blue. There was no time criterion used other than the two month time period. The average profiles agree to within $5 \%$ in the stratosphere above $18 \mathrm{~km}$.

Below the hygropause there is some possibility that ACE-FTS may be a little bit dry. 15 Figure 20, presenting a great number of ACE-FTS data points, shows also how well the instrument captures the natural variability of water, in perfect agreement with $\mathrm{CFH}$.

\subsection{PCL Lidar}

The University of Western Ontario's Purple Crow Lidar (PCL) is a powerful Rayleigh resonance-scatter and Raman lidar system. It is located at the Delaware Observa20 tory, just southwest of London, Ontario (Sica et al., 1995). The transmitter for the Rayleigh and Raman channels uses a frequency doubled YAG laser, which produces $600 \mathrm{~mJ}$ pulses at a pulse-repetition-frequency of $20 \mathrm{~Hz}$, i.e. $12 \mathrm{~W}$ average power, at a wavelength of $532 \mathrm{~nm}$. The PCL receiver is based on a $2.65 \mathrm{~m}$ diameter liquid mercury mirror. The use of this large mirror allows high signal-to-noise ratio Raman water 25 vapour and molecular nitrogen returns to be obtained at altitudes above $20 \mathrm{~km}$. Separate detection system channels record the backscatter intensity profiles for the two Raman channels, in addition to the high-altitude Rayleigh-scatter and sodium resonance channels. For these comparisons, the lidar measurements were averaged over

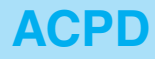

$8,4499-4559,2008$

ACE water vapour validation

M. R. Carleer et al.

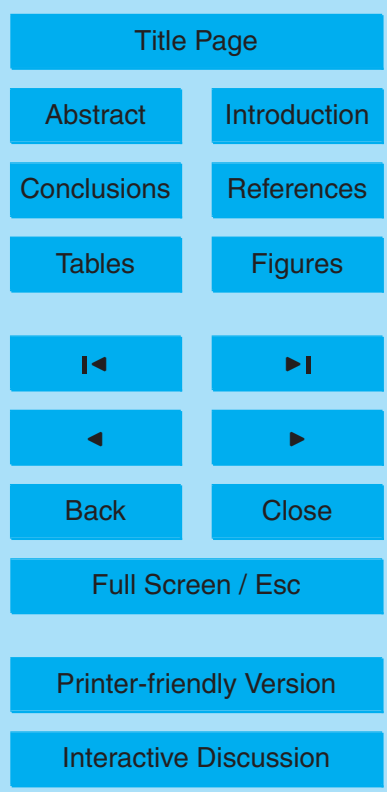


a night's integration to minimize the statistical error.

The PCL lidar water vapour measurements and stratospheric-vibrational-Ramanscattering temperatures have been calibrated against routine radiosonde measurements from Detroit, MI and Buffalo, NY by Argall et al. (2007). Their comparison 5 showed the lidar measurements were typically greater below $2 \mathrm{~km}$ and lower between 4 and $8 \mathrm{~km}$ than the radiosondes, but in general agreed to within about $\pm 12 \%$. This agreement is consistent with the uncertainties in the radiosondes themselves and the tropospheric geophysical variability between the locations.

Four ACE-FTS overpasses were available for comparison. The PCL measurements 10 used for the comparisons are mean values of individual profiles taken during one night when one overpass of ACE-FTS occurred. Careful inspection of the individual PCL profiles showed no temporal variation during the observing periods, justifying the use of a nightly-averaged profile. Furthermore, each night was free of clouds during the measurement period. The proximity of each coincidence is given in Table 1. The coincidence on 1 September 2005 was in close proximity to the PCL. The coincidences on 2 September 2005 and 5 May 2006 are at approximately the same latitude, but about $10^{\circ}$ of longitude to the west. The coincidence on 30 June 2006 was significantly north, e.g. about $6^{\circ}$ in latitude.

Figure 21 shows the coincidence on 30 June 2005, where ACE-FTS is north of the 20 PCL. This is the only coincidence where ACE-FTS measurements were not available below $12 \mathrm{~km}$. There is general agreement below $16 \mathrm{~km}$, but the lidar measurement show a general increase of water vapour VMR with height. Above $16 \mathrm{~km}$ the lidar measurements are about twice that of ACE-FTS. It should be noted that the validity of the PCL measurement at $18.75 \mathrm{~km}$ is questionable, although nothing unusual was found in the lidar returns.

The coincidence on 1 September 2005 (Fig. 22) is the closest spatially to the PCL. The general shape of the two measurements is similar, but the ACE-FTS VMRs are about 10 times larger in the troposphere. Around the tropopause region the measurements agree, but above $11.5 \mathrm{~km}$ the PCL measurements sharply decrease and remain

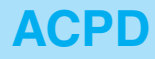

$8,4499-4559,2008$

ACE water vapour validation

M. R. Carleer et al.

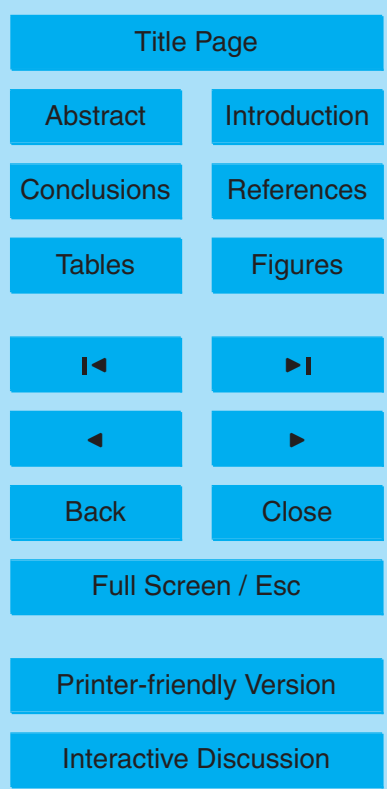

EGU 
about 5 times smaller then ACE-FTS. Both the lidar temperature measurements and Detroit radiosonde show the tropopause height to be around $17 \mathrm{~km}$, corresponding to the second water vapour increase in the PCL profile (Sica et al., 2008).

The coincidences on 2 September 2005 (Fig. 23) and 5 May 2006 (Fig. 24) use

5 ACE-FTS measurements obtained to the west of the PCL. On 2 September 2005 both instruments measure higher VMRs in the upper troposphere, but again there is a large difference in the magnitude of the ratios, with the ACE-FTS measurements about twice the PCL measurements. In fact, on this night the ACE-FTS measurements are greater at all heights. While the PCL measures a rapid decrease in VMR above $10 \mathrm{~km}$, similar 10 to the previous night, the ACE-FTS measurements are much larger in this region (about 10 times). Above $14 \mathrm{~km}$, the measurements agree to about $50 \%$. The coincidence on 5 May 2006 shows the best agreement. Both instruments measure a profile of similar shape, and both observe a minimum at $14.5 \mathrm{~km}$ altitude. Both the lidar and the Detroit radiosonde see a temperature minimum at this height (Sica et al., 2008).

15 Above this height, the ACE-FTS measurements agree within the errors and are slightly smaller than the PCL measurements. Below this height, the shape of each profile is the same but again the ACE-FTS measurement is about 2 to 5 times greater than the PCL measurements

\section{ACE-MAESTRO/ACE-FTS comparison}

20 We chose to compare median average profiles of ACE-MAESTRO and ACE-FTS in 4 latitudinal bands in September-October 2005: 70-75 degrees north, 30 north to 30 south, 35-60 degrees south and 60-70 degrees south. Data availability was limited at northern mid-latitudes in this time period. The band widths were chosen to have at least 20 profiles per band.

25 Because ACE-MAESTRO and ACE-FTS are aboard the same satellite, they share the same pointing optics. However, due to slight differences in the optical path and sampling time and, more importantly, due to the different refraction indices of the op-

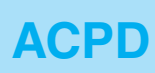

8, 4499-4559, 2008

ACE water vapour validation

M. R. Carleer et al.

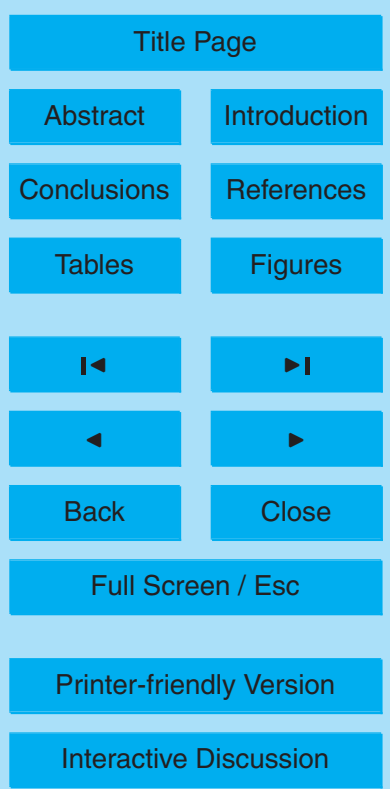


tical versus infrared light in the atmosphere, slight discrepancies in the geophysical location are present. They will be small however. Differences in the water vapour profile may also result from differences between the instruments in terms of spatial resolution, particularly in the vertical direction. ACE-MAESTRO has a vertical resolu5 tion of $\sim 1.2 \mathrm{~km}$ (McElroy et al., 2007). The only difference between ACE-MAESTRO and ACE-FTS which is consistent versus latitude occurs below $12-15 \mathrm{~km}$, where ACEFTS is sensitive to the assumed shape of the ro-vibrational absorption lines it uses to quantify water vapour concentration. The line shape issue requires further modelling (Boone et al., 2007).

10 Figures 25 to 28 present the comparisons between the vertical profiles for the 4 latitudinal bands. Because ACE-MAESTRO currently gives noisy values in the middle stratosphere, comparisons are limited to altitudes lower than $19 \mathrm{~km}$. It can be seen from these figures that the agreement between ACE-FTS and ACE-MAESTRO are very good in general, certainly well within the error bars. The generally good agreement 15 between the profiles may well be due to the very good pointing collocation of the two instruments, removing any spatial variability of the water content known to be high in the troposphere. Even when comparing single profiles instead of averages, the agreement is good.

Figure 28 shows two minima in the ACE-MAESTRO water vapour concentration at roughly 14.5 and $17.5 \mathrm{~km}$. Cloud filtering of the profiles used in the median calculation reduces the amplitude of the minima. This suggests that a real dehydration process occurs at the two altitudes, particularly in the presence of PSCs. The lack of minima in the ACE-FTS is thought to be due to the lower vertical resolution of the ACE-FTS.

\section{Summary and conclusions}

25 In this study, ACE-FTS version 2.2 water vapour profiles were compared with measurements from the satellite-based instruments SAGE II, HALOE, POAM III, MIPAS and SMR as well as balloon-borne frostpoint hygrometer and ground-based lidar ob-

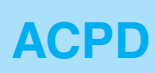

$8,4499-4559,2008$

ACE water vapour validation

M. R. Carleer et al.

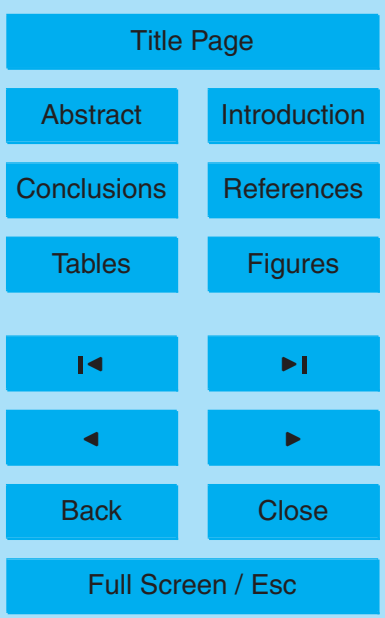

Printer-friendly Version

Interactive Discussion 
servations. A new $\mathrm{H}_{2} \mathrm{O}$ product from ACE-MAESTRO was also introduced and initial comparisons with ACE-FTS were described.

Apart from POAM III, the comparisons made with the instruments onboard satellites all show a slight positive bias of the ACE-FTS of the order of 3 to $10 \%$ in the altitude 5 range 15 to $70 \mathrm{~km}$. However taking into account the conclusions drawn by the various papers validating SAGE II, HALOE and POAM III, the accuracy of the ACE-FTS water vapor VMR can be estimated to be better than the comparisons by several percent. The comparison with Odin-SMR also shows a roughly constant wet bias of $0.4 \mathrm{ppmv}$ from 50 to $90 \mathrm{~km}$. Note as described in Sect. 3.1.5., that the remaining calibration 10 issues of the Odin-SMR instrument may cause a small low bias that could be of the same magnitude as the aforementioned difference. That all space-borne instruments comparisons show an ACE-FTS positive difference near $10 \mathrm{~km}$ possibly suggests a real bias in the ACE-FTS data at low altitude. The same is true when comparing ACE-FTS with the Purple Crow Lidar. Note, however, that variability in $\mathrm{H}_{2} \mathrm{O}$ increases 15 substantially near the tropopause, so it is also possible that geophysical variations contribute to these differences. The results obtained from the comparison with the hygrometers seem to be in contradiction with the findings above. They suggest that ACE-FTS is often dryer in the troposphere.

The variability in the upper troposphere (below the hygropause) is quite large, so one needs good coincidences to make substantial statements. However in order to have statistically meaningful averages, we had to relax the coincidence criteria. We might just be sampling the variability of the upper troposphere, not the differences in the instruments.

Finally, the comparisons with ACE-MAESTRO do not consistently show a significant 25 wet or dry bias at $10 \mathrm{~km}$. This could be partly due to the fact that some errors (e.g. altitude registration) are common to both ACE instruments and thus are not revealed by this internal comparison.

In view of all the results shown here and the discussion about the validity of the measurements made by the other instruments, we certainly can conclude that the ACE-FTS

ACE water vapour validation

M. R. Carleer et al.

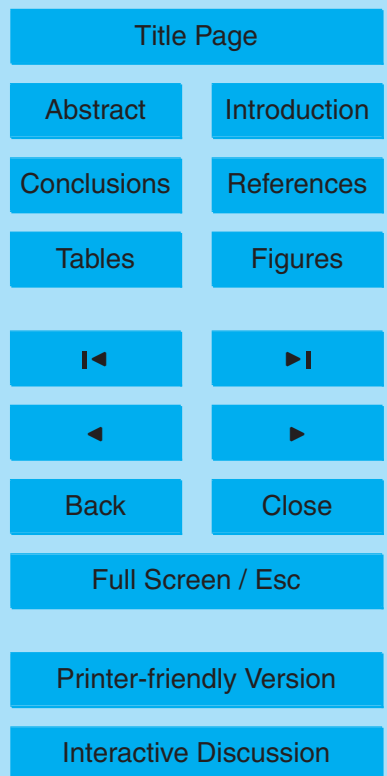

EGU 
water vapour measurements are in very good agreement with most of the comparison instruments to a level better than $5-10 \%$ in the stratosphere from 15 to $70 \mathrm{~km}$. This difference increases gradually above $70 \mathrm{~km}$. The situation below $15 \mathrm{~km}$ is more difficult to establish since the space-borne instruments show an ACE-FTS wet bias but the 5 hygrometers show a dry bias at the same altitudes. The discrepancy here can be as high as $40 \%$ with the other instruments. However it is well known that the water vapour content in the troposphere can vary wildly both spatially and temporally.

The high repeatability of ACE-FTS in the stratosphere relative to MIPAS, POAM III, ACE-MAESTRO, and SAGE II, combined with the small biases relative to the ensem10 ble of correlative instruments and the good geographical coverage provided by the mid-inclination orbit suggests that ACE-FTS is probably the best available satellite instrument for validating future water vapour profilers. The high precision of ACE data makes it useful for trend studies (Nassar et al., 2005a), descent rate calculations (Nassar et al., 2005b), and other process studies.

15 All the results discussed above are for mean profiles calculated, for most of them, from hundreds and even thousands of profiles. In one particular case, the PCL lidar, single profiles were compared. Values differing by as much as a factor of 10 are seen. In this case the spatial variability becomes one of the most important factors because the variability is not minimized by averaging. A possible temporal variability was excluded by making lidar measurements during several hours and checking that the water vapor content remained almost constant. Also, the inherent differences in the measurement techniques can impact these comparisons. The lidar observation collects its signal from a narrow column of air above the station whereas the solar occultation measurement by ACE-FTS averages over a $\sim 500 \mathrm{~km}$ horizontal path length 25 through the atmosphere.

Acknowledgements. The Atmospheric Chemistry Experiment (ACE), also known as SCISAT, is a Canadian-led mission mainly supported by the Canadian Space Agency and the Natural Sciences and Engineering Research Council of Canada. The MAESTRO instrument was developed with additional financial support from Environment Canada, the Canadian Foundation

ACE water vapour validation

M. R. Carleer et al.

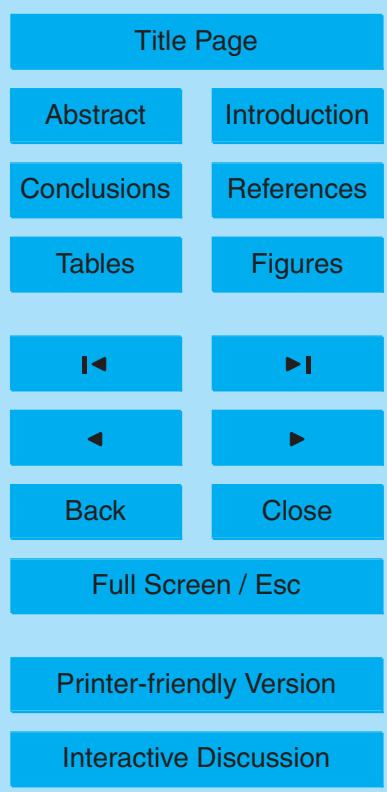

EGU 
for Climate and Atmospheric Sciences, and the Natural Sciences and Engineering Research Council of Canada.

The research in Belgium was funded by the F.R.S.-FNRS, the Belgian State Federal Office for Scientific, Technical and Cultural Affairs and the European Space Agency (ESA-Prodex 5 arrangement C90-219) as well as by the "Actions de Recherche Concertées" (Communauté Française de Belgique).

The authors thank the HALOE Science and Data Processing Teams for providing the profiles used in this work. Thanks to the POAM team at the U.S. Naval Research Lab for providing the POAM III data. We also thank the SAGE II team for providing the data used in these compar10 isons. We are grateful to L. Harvey for processing the data used in the SAGE II, HALOE and POAM III comparisons. We acknowledge financial support from NASA grant NNG04GF39G.

Odin is a Swedish-led satellite project funded jointly by the Swedish National Space Board (SNSB), the Canadian Space Agency (CSA), the National Technology Agency of Finland (Tekes) and the Centre National d'Etudes Spatiales (CNES) in France. The Swedish Space

We also acknowledge ESA for providing the MIPAS level 1b-dataset.

\section{References}

Abbas, M. M., Gunson, M. R., Newchurch, M. J., Michelsen, H. A., Salawitch, R. J., Allen, M., Abrams, M. C., Chang, A. Y., Goldman, A., Irion, F. W., Moyer, E. J., Nagaraju, R., Rinsland, C. P., Stiller, G. P., and Zander, R.: The hydrogen budget of the stratosphere inferred from ATMOS measurements of $\mathrm{H}_{2} \mathrm{O}$ and $\mathrm{CH}_{4}$, Geophys. Res. Lett., 23(17), 2405-2408, doi:10.1029/96GL01320, 1996.

Argall, P. S., Sica, R.J., Bryant, C., Algara-Siller, M., and Schijns, H.: Calibration of the Purple Crow Lidar Raman water vapour and temperature measurements, Can. J. Phys., 85, 119129, 2007.

Barath, F. T., Chavez, M. C., Cofield, R. E., Flower, D. A., Frerking, M. A., Gram, M. B., Harris, W. M., Holden, J. R., Jarnot, R. F., and Kloezeman, W. G.: The Upper Atmosphere Research Satellite microwave limb sounder instrument, J. Geophys. Res., 98(D6), 1075110762, doi:10.1029/93JD00798, 1993.

ACE water vapour validation

M. R. Carleer et al.

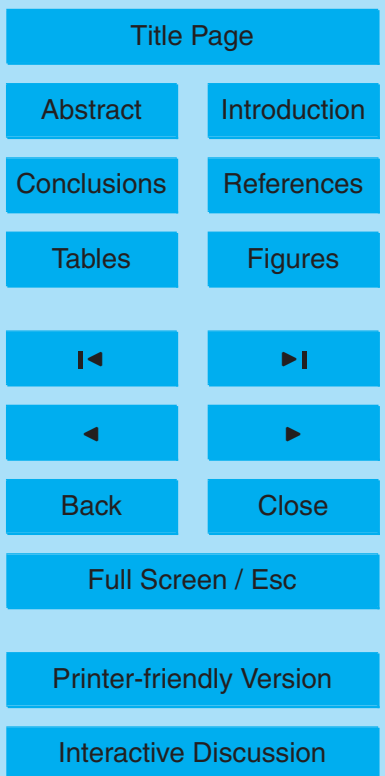

EGU 
Bernath, P. F., McElroy, C. T., Abrams, M. C., Boone, C. D., Butler, M., Camy-Peyret, C., Carleer, M., Clerbaux, C., Coheur, P. F., Colin, R., DeCola, P., DeMaziere, M., Drummond, J. R., Dufour, D., Evans, W. F. J., Fast, H., Fussen, D., Gilbert, K., Jennings, D. E., Llewellyn, E. J., Lowe, R. P., Mahieu, E., McConnell, J. C., McHugh, M., McLeod, S. D., Michaud, R., $5 \quad$ Midwinter, C., Nassar, R., Nichitiu, F., Nowlan, C., Rinsland, C. P., Rochon, Y. J., Rowlands, N., Semeniuk, K., Simon, P., Skelton, R., Sloan, J. J., Soucy, M.-A., Strong, K., Tremblay, P., Turnbull, D., Walker, K. A., Walkty, I., Wardle, D. A., Wehrle, V., Zander, R., and Zou, J.: Atmospheric Chemistry Experiment (ACE): Mission overview, Geophys. Res. Lett., 32, L15S01, doi:10.1029/2005GL022386, 2005.

10 Berk, A., Anderson, G. P., Acharya, P. K., Chetwynd, J. H., Bernstein, L. S., Shettle, E. P., Matthew, M. W., and Adler-Golden, S. M.: MODTRAN4 User's manual: Software manual, Air Force Res. Lab., Space Vehicles Dir., Air Force Mater. Command, Hanscom Air Force Base, Mass., 1999.

Boone, C. D., Nassar, R., Walker, K. A., Rochon, Y., McLeod, S. D., Rinsland, C. P., and Bernath, P. F.: Retrievals for the atmospheric chemistry experiment Fourier-transform spectrometer, Appl. Optics, 44, 7218-7231, 2005.

Boone, C. D., Walker, K. A., and Bernath, P. F.: Speed-dependent Voigt profile for water vapour in infrared remote sensing applications, J. Quant. Spectrosc. Radiat. Transfer, 525-532, 2007.

Chahine, M. T.: Inverse problems in radiative transfer: Determination of atmospheric parameters, J. Atmos. Sci., 27, 960-967, 1970.

Chiou, E.-W., McCormick, M. P., McMaster, L. R., Chu, W. P., Larsen, J. C., Rind, D., and Oltmans, S.: Intercomparison of stratospheric water vapour observed by satellite experments: SAGE II versus LIMS and ATMOS, J. Geophys. Res., 98, 4875-4887, 1993.

Chiou, E.-W., Thomason, L. W., Burton, S. P., and Michelsen, H. A.: Assessment of the SAGE II version 6.2 water vapour data set through intercomparison with ATMOS/ATLAS-3 measurements, Geophys. Res. Lett., 31, L14101, doi:10.1029/2004GL020071, 2004.

Chu, W. P., Chiou, E. W., Larsen, J. C., Thomason, L. W., Rind, D., Buglia, J. J., Oltmans, S., McCormick, M. P., and McMaster, L. R.: Algorithms and sensitivity analyses for SAGE II water vapour retrieval, J. Geophys. Res., 98, 4857-4866, 1993.

De Mazière, M., Vigouroux, C., Bernath, P. F., Baron, P., Blumenstock, T., Boone, C., Brogniez, C., Catoire, V., Coffey, M., Duchatelet, P., Griffith, D., Hannigan, J., Kasai, Y., Kramer, I., Jones, N., Mahieu, E., Manney, G. L., Piccolo, C., Randall, C., Robert, C., Senten, C.,

ACE water vapour validation

M. R. Carleer et al.

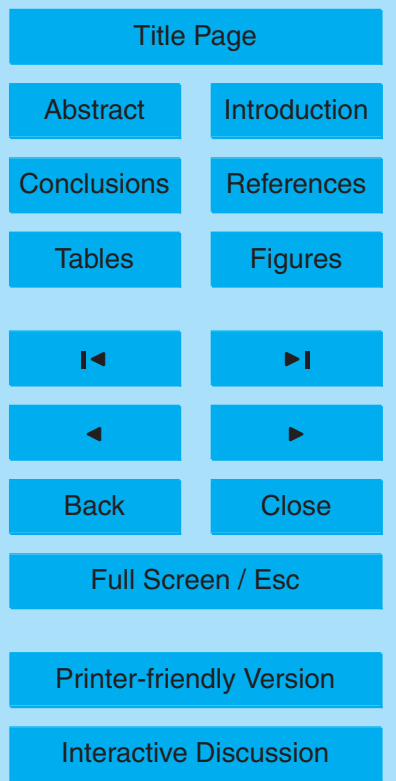


Strong, K., Taylor, J., Tétard, C., Walker, K. A., and Wood, S.: Validation of ACE-FTS v2.2 methane profiles from the upper troposphere to lower mesosphere, Atmos. Chem. Phys. Discuss., 7, 17 975-18014, 2007.

Drummond, J. R., Houghton, J. T., Peskett, G. D., Rodgers, C. D., Wale, M. J., Whitney, J., and Williamson, E. J.: The Stratospheric and Mesospheric Sounder on Nimbus 7, Philosophical Transactions of the Royal Society of London, Series A, Math. Phys. Sci., 296, 219-241, 1980.

Fischer, H., Gille, J., and Russell, J.: Water vapour in the stratosphere: preliminary results of the LIMS experiment aboard Nimbus-7, Adv. Space Res., 1, 279-281, 1981.

10 Fischer, H., Birk, M., Blom, C., Carli, B., Carlotti, M., von Clarmann, T., Delbouille, L., Dudhia, A., Ehhalt, D., Endemann, M., Flaud, J. M., Gessner, R., Kleinert, A., Koopmann, R., Langen, J., López-Puertas, M., Mosner, P., Nett, H., Oelhaf, H., Perron, G., Remedios, J., Ridolfi, M., Stiller, G., and Zander, R.: MIPAS: an instrument for atmospheric and climate research, Atmos. Chem. Phys. Discuss., 7, 8795-8893, 2007,

15 http://www.atmos-chem-phys-discuss.net/7/8795/2007/.

Frisk, U., Hagström, M., Ala-Laurinaho, J., Andersson, S., Berges, J.-C., Chabaud, J.-P., Dahlgren, M., Emrich, A., Florén, H.-G., Florin, G., Fredrixon, M., Gaier, T., Haas, R., Hirvonen, T., Hjalmarsson, A., Jakobsson, B., Jukkala, P., Kildal, P. S., Kollberg, E., Lassing, J., Lecacheux, A., Lehikoinen, P., Lehto, A., Mallat, J., Marty, C., Michet, D., Narbonne, J., Nexon, M., Olberg, M., Olofsson, A. O. H., Olofsson, G., Origné, A., Petersson, M., Piironen, P., Pons, R., Pouliquen, D., Ristorcelli, I., Rosolen, C., Rouaix, G., Räisänen, A. V., Serra, G., Sjöberg, F., Stenmark, L., Torchinsky, S., Tuovinen, J., Ullberg, C., Vinterhav, E., Wadefalk, N., Zirath, H., Zimmermann, P., and Zimmermann, R.: The Odin satellite: I. Radiometer design and test, Astron. Astrophys., 402, L27-L34, doi:10.1051/0004-6361:20030335, 2003.

Gattinger, R. L., Boone, C. D., Walker, K. A., Degenstein, D. A., Bernath, P. F., and Llewellyn, E. $\mathrm{J}$.: Comparison of Odin-OSIRIS OH A ${ }^{2} \Sigma^{+}-\mathrm{X}^{2} \Pi$ 0-0 mesospheric observations and ACE-FTS water vapour observations, Geophys. Res. Lett., 33, L15808, doi:10.1029/2006GL026425, 2006.

Gille, J. C., Bailey, P. L., and Russell III, J. M.: Temperature and composition measurements 30 from the I.r.i.r. and I.i.m.s. experiments on Nimbus 6 and 7, Philosophical Transactions of the Royal Society of London, Series A, Math. Phys. Sci., 296, 205-218, 1980.

Goss-Custard, M., Remedios, J. J., Lambert, A., Taylor, F. W., Rodgers, C. D., LopezPuertas, M., Zaragoza, G., Gunson, M. R., Suttie, M. R., Harries, J. E., and Rus-

ACE water vapour validation

M. R. Carleer et al.

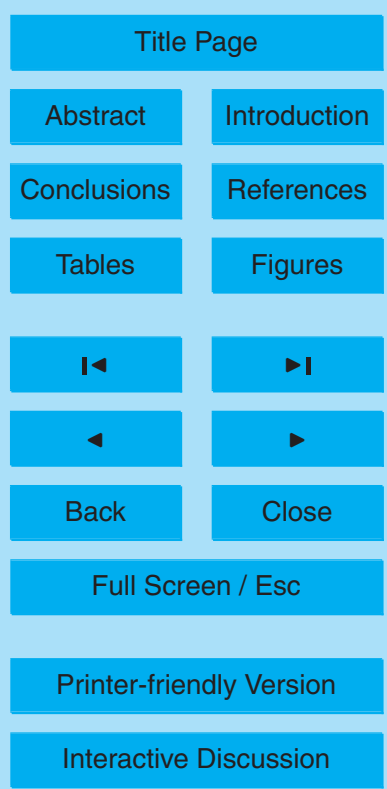


sell, J. M.: Measurements of water vapor distributions by the improved stratospheric and mesospheric sounder: Retrieval and validation, J. Geophys. Res., 101(D6), 9907-9928, doi:10.1029/95JD02032, 1996.

Griesfeller, A., von Clarmann, T., Griesfeller, J., Höpfner, M., Milz, M., Nakajima, H., Steck, T., $5 \quad$ Sugita, T., Tanaka, T., and Yokota, T.: Intercomparison of ILAS-II Version 1.4 and Version 2 target parameters with MIPAS-Envisat measurements, Atmos. Chem. Phys., 8, 825-843, 2008

http://www.atmos-chem-phys.net/8/825/2008/.

Gunson, M. R., Abbas, M. M., Abrams, M. C., Allen, M., Brown, L. R., Brown, T. L., Chang, A. Y., Goldman, A., Irion, F. W., Lowes, L. L., Mahieu, E., Manney, G. L., Michelsen, H. A., Newchurch, M. J., Rinsland, C. P., Salawitch, R. J., Stiller, G. P., Toon, G. C., Yung, Y. L., and Zander, R.: The Atmospheric Trace Molecule Spectroscopy (ATMOS) experiment: Deployment on the ATLAS Space Shuttle missions, Geophys. Res. Lett., 23(17), 2333, doi:10.1029/96GL01569, 1996.

Harries, J. E., Russell, J. M., Tuck, A. F., Gordley, L. L., Purcell, P., Stone, K., Bevilacqua, R. M., Gunson, M., Nedoluha, G., and Traub, W. A.: Validation of measurements of water vapour from the Halogen Occultation Experiment (HALOE), J. Geophys. Res., 101(D6), 10205$10216,1996$.

Hartmann, G. K., Bevilacqua, R. M., Schwartz, P. R., Kämpfer, N., Künzi, K. F., Aellig, C. P., Berg, A., Boogaerts, W., Connor, B. J., Croskey, C. L., Daehler, M., Degenhardt, W., Dicken, H. D., Goldizen, D., Kriebel, D., Langen, J., Loidl, A., Olivero, J. J., Pauls, T. A., Puliafito, S. E., Richards, M. L., Rudin, C., Tsou, J. J., Waltman, W. B., Umlauft, G., and Zwick, R.: Measurements of $\mathrm{O}_{3}, \mathrm{H}_{2} \mathrm{O}$ and $\mathrm{ClO}$ in the middle atmosphere using the millimeter-wave atmospheric sounder (MAS), Geophys. Res. Lett., 23(17), 2313-2316, doi:10.1029/96GL01475, 1996.

Hervig, M. and Siskind, D.: Decadal and inter-hemispheric variability in polar mesospheric clouds, water vapor, and temperature, J. Atmos. Solar-Terr. Phys., 68, 30-41, 2006.

Hoppel, K. W., Bowman K. P., and Bevilacqua R. M.: Northern hemisphere summer ozone variability observed by POAM II, Geophys. Res. Lett., 26, 827-830, 1999.

so Kanzawa, H., Schiller, C., Ovarlez, J., Camy-Peyret, C., Payan, S., Jeseck, P., Oelhaf, H., Stowasser, M., Traub, W. A., Jucks, K. W., Johnson, D. G., Toon, G. C., Sen, B., Blavier, J.-F., Park, J. H., Bodeker, G. E., Pan, L. L., Sugita, T., Nakajima, H., Yokota, T., Suzuki, M., Shiotani, M., and Sasano, Y.: Validation and data characteristics of water vapor profiles

\section{ACPD}

$8,4499-4559,2008$

ACE water vapour validation

M. R. Carleer et al.

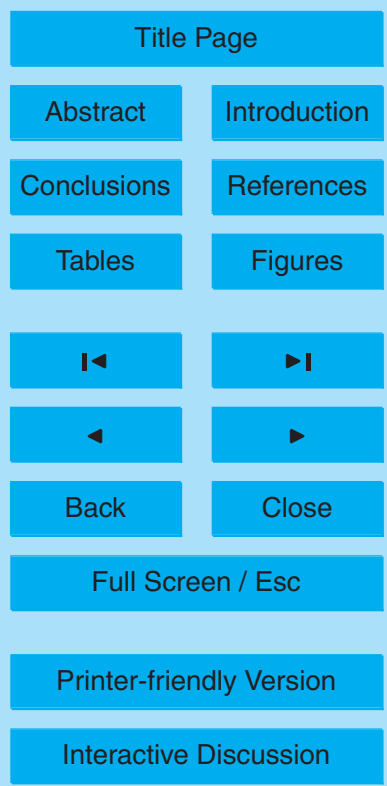


observed by the Improved Limb Atmospheric Spectrometer (ILAS) and processed with the version 5.20 algorithm, J. Geophys. Res., 107(D24), 8217, doi:10.1029/2001JD00881, 2002. (Correction: J. Geophys. Res., 108(D4), 8218, doi:10.1029/2003JD001601, 2003).

Kley, D., Russell III, J. M., and Phillips, C.: SPARC assessment of upper tropospheric and 5 stratospheric water vapour, WCRP 113, WMO/TD-1043, SPARC Rep. 2, World Clim. Res. Program, Geneva, 2000.

Lambert, A., Read, W. G., Livesey, N. J., Santee, M. L., Manney, G. L., Froidevaux, L., Wu, D. L., Schwartz, M. J., Pumphrey, H. C., Jimenez, C., Nedoluha, G. E., Cofield, R. E., Cuddy, D. T., Daffer, W. H., Drouin, B. J., Fuller, R. A., Jarnot, R. F., Knosp, B. W., Pickett, H. M., Perun, V. S., Snyder, W. V., Stek, P. C., Thurstans, R. P., Wagner, P. A., Waters, J. W., Jucks, K. W., Toon, G. C., Stachnik, R. A., Bernath, P. F., Boone, C. D., Walker, K. A., Urban, J., Murtagh, D., Elkins, J. W., and Atlas, E.: Validation of the Aura Microwave Limb Sounder stratospheric water vapour and nitrous oxide measurements, J. Geophys. Res., 112, D24S36, doi:10.1029/2007JD008724, 2007.

Lossow, S., Urban, J., Eriksson, P., Murtagh, D., and Gumbel, J.: Critical parameters for the retrieval of mesospheric water vapour and temperature from Odin/SMR limb measurements at 557 GHz, Adv. Space Res., 40, 835, doi:10.1016/j.asr.2007.05.026, 2007.

Lucke, R. L., Korwan, D. R., Bevilacqua, R. M., Hornstein, J. S., Shettle, E. P., Chen, D. T., Daehler, M., Lumpe, J. D., Fromm, M. D., Debrestian, D., Neff, B., Squire, M., König-Langlo, G., and Davies, J.: The Polar Ozone and Aerosol Measurement (POAM) III instrument and early validation results, J. Geophys. Res., 104(D15), 18785-18800, doi:10.1029/1999JD900235, 1999.

Lumpe, J. D., Bevilacqua, R., Randall, C., Nedoluha, G., Hoppel, K., Russell, J., Harvey, V.L., Schiller, C., Sen, B., Taha, G., Toon, G., and Vomel, H.: Validation of Polar Ozone and Aerosol Measurement (POAM) III version 4 stratospheric water vapour, J. Geophys. Res., 111, D11301, doi:10.1029/2005JD006763, 2006.

Mahieu, E., Duchatelet, P., Demoulin, P., Walker, K. A., Dupuy, E., Froidevaux, L., Randall, C., Catoire, V., Strong, K., Boone, C. D., Bernath, P. F., Blavier, J.-F., Blumenstock, T., Coffey, M., De Mazière, M., Griffith, D., Hannigan, J., Hase, F., Jones, N., Jucks, K. W., Kagawa, A., Kasai, Y., Mebarki, Y., Mikuteit, S., Nassar, R., Notholt, J., Rinsland, C. P., Robert, C., Schrems, O., Senten, C., Smale, D., Taylor, J., Tétard, C., Toon, G. C., Warneke, T., Wood, S. W., Zander, R., and Servais, C.: Validation of ACE-FTS v2.2 measurements of HCl, HF, $\mathrm{CCl} 3 \mathrm{~F}$ and $\mathrm{CCl} 2 \mathrm{~F} 2$ using space-, balloon- and ground-based instrument observations, At-

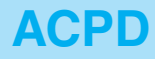

$8,4499-4559,2008$

ACE water vapour validation

M. R. Carleer et al.

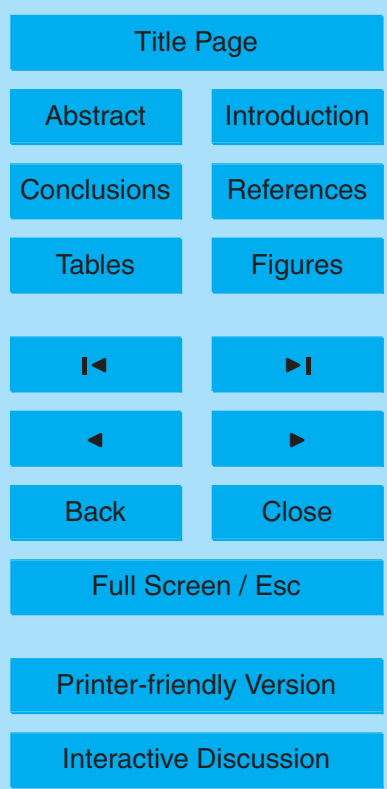

EGU 
mos. Chem. Phys. Discuss., 8, 3431-3495, 2008,

http://www.atmos-chem-phys-discuss.net/8/3431/2008/.

Mauldin, L. E. III, Zaun, N. H., McCormick, M. P., Guy, J. H., and Vaughn, W. R.: Stratospheric Aerosol and Gas Experiment II instruments: A functional description, Opt. Eng., 24, 307$5312,1985$.

McElroy, C. T., Nowlan, C. R., Drummond, J. R., Bernath, P. F., Barton, D. V., Dufour, D. G., Midwinter, C., Hall, R. B., Ogyu, A., Ullberg, A., Wardle, D. I., Kar, J., Zou, J., Nichitiu, F., Boone, C. D., Walker, K. A., and Rowlands, N.: The ACE-MAESTRO instrument on SCISAT: description, performance, and preliminary results, Appl. Optics, 46, 4341-4356, 2007.

10 Michelsen, H. A., Irion, F. W., Manney, G. L., Toon, G. C., and Gunson, M. R.: Features and trends in ATMOS Version 3 water vapor and methane measurements, J. Geophys. Res., 105, 22 713-22 724, 2000.

Michelsen, H. A., Manney, G. L., Irion, F. W., Toon, G. C., Gunson, M. R., Rinsland, C. P., Zander, R., Mahieu, E., Newchurch, M. J., Purcell, P. N., Remsberg, E. E., Russell III, J. M., Pumphrey, H. C., Waters, J. W., Bevilacqua, R. M., Kelly, K. K., Hintsa, E. J., Weinstock, E. M., Chiou, E.-W., Chu, W. P., McCormick, M. P., and Webster C. R.: ATMOS version 3 water vapour measurements: Comparisons with observations from two ER-2 Lyman- $\alpha$ hygrometers, MkIV, HALOE, SAGE II, MAS, and MLS, J. Geophys. Res., 107(D3), 4027, doi:10.1029/2001JD000587, 2002.

Milz, M., von Clarmann, T., Fischer, H., Glatthor, N., Grabowski, U., Höpfner, M., Kellmann, S., Kiefer, M., Linden, A., Mengistu Tsidu, G., Steck, T., Stiller, G.P., Funke, B., and LópezPuertas, M.: Water vapour distributions measured with the Michelson Interferometer for Passive Atmospheric Sounding on board Envisat (MIPAS/Envisat) J. Geophys. Res., 110(D24), D24307, doi:10.1029/2005JD005973, 2005.

Mote, P. W., Rosenlof, K. H., Mclntyre, M. E., Carr, E. S., Gille, J. C., Holton, J. R., Kinnersley, J. S., Pumphrey, H. C., Russell III, J. M., and Waters, J. W.: An atmospheric tape recorder: The imprint of tropical tropopause temperatures on stratospheric water vapor, J. Geophys. Res., 101(D2), 3989-4006, 1996.

Murtagh, D. P., Frisk, U., Merino, F., Ridal, M., Jonsson, A., Stegman, J., Witt, G., Eriksson, P., Jiménez, C., Mégie, G., de la Noë, J., Ricaud, P., Baron, P., Pardo, J. R., Hauchecorne, A., Llewellyn, E. J., Degenstein, D. A., Gattinger, R. L., Lloyd, N. D., Evans, W. F. J., McDade, I. C., Haley, C. S., Sioris, C., von Savigny, C., Solheim, B. H., McConnell, J. C., Strong, K., Richardson, E. H., Leppelmeier, G. W., Kyrölä, E., Auvinen, H., and Oikarinen, L.: An

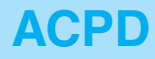

$8,4499-4559,2008$

ACE water vapour validation

M. R. Carleer et al.

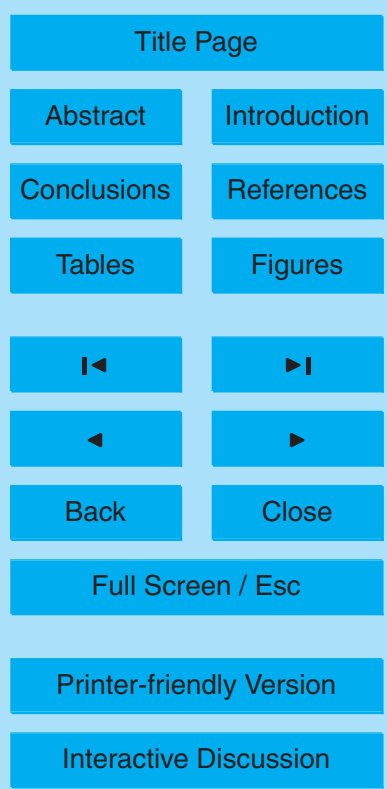

EGU 
overview of the Odin atmospheric mission, Can. J. Phys., 80, 309-319, 2002.

Nakajima, H., Suzuki, M., Matsuzaki, A., Ishigaki, T., Waragai, K., Mogi, Y., Kimura, N., Araki, N., Yokota, T., Kanzawa, H., Sugita, T., and Sasano, Y.: Characteristics and performance of the Improved Limb Atmospheric Spectrometer (ILAS) in orbit, J. Geophys. Res., 107(D24), 8213, doi:10.1029/2001JD001439, 2002.

Nakajima, H., Sugita, T., Yokota, T., Ishigaki, T., Mogi, Y., Araki, N., Waragai, K., Kimura, N., Iwazawa, T., Kuze, A., Tanii, J., Kawasaki, H., Horikawa, M., Togami, T., Uemura, N., Kobayashi, H., and Sasano, Y.: Characteristics and performance of the Improved Limb Atmospheric Spectrometer-II (ILAS-II) on board the ADEOS-II satellite, J. Geophys. Res., 111,

10 D11S01, doi:10.1029/2005JD006334, 2006.

Nassar, R., Bernath, P. F., Boone, C. D., Manney, G. L., McLeod, S. D., Rinsland, C. P., Skelton, R., and Walker, K. A.: Stratospheric abundances of water and methane based on ACE-FTS measurements, Geophys. Res. Lett., 32, L15S04, doi:10.1029/2005GL022383, 2005a.

Nassar, R., Bernath, P. F., Boone, C. D., Manney, G. L., McLeod, S. D., Rinsland, C. P., Skelton, 15 R., and Walker, K. A.: ACE-FTS measurements across the edge of the winter 2004 Arctic vortex, Geophys. Res. Lett., 32, L15S05, doi:10.1029/2005GL022671, 2005b.

Nedoluha, G. E., Bevilacqua, L. M., Gomez, R. M., Waltman, W. B., Hicks, B. C., Thacker, D. L., and Matthews, W. A.: Measurements of water vapor in the middle atmosphere and implications for mesospheric transport, J. Geophys. Res., 101, 21 183-21 193, 1996.

20 Nedoluha, G. E., Bevilacqua, R. M., Gomez, R. M., Waltman, W. B., Hicks, B. C., Thacker, D. L., Russell III, J. M., Abrams, M., Pumphrey, H. C., and Connor, B. J.: A comparative study of mesospheric water vapor measurements from the ground-based water vapor millimeter-wave spectrometer and space-based instruments, J. Geophys. Res., 102(D14), 16647-16661, doi:10.1029/97JD01095, 1997.

Nedoluha, G. E., Bevilacqua, R. M., Gomez, R. M., Hicks, B. C., Russell III, J. M., and Connor, B. J. : An evaluation of trends in middle atmospheric water vapour as measured by HALOE, WVMS, and POAM, J. Geophys. Res., 108(D13), 4391, doi:10.1029/2002JD003332, 2003.

Offermann, D., Grossmann, K. U., Barthol, P., Knieling, P., Riese, M., and Trant, R.: Cryogenic Infrared Spectrometers and Telescopes for the Atmosphere (CRISTA) experiment and middle 30 atmosphere variability, J. Geophys. Res., 104(D13), 16 311-16 325, 1999.

Offermann, D., Schaeler, B., Riese, M., Langfermann, M., Jarisch, M., Eidmann, G., Schiller, C., Smit, H. G. J., and Read, W. G.: Water vapor at the tropopause during the CRISTA 2 mission, J. Geophys. Res., 107(D23), 8176, doi:10.1029/2001JD000700, 2002.

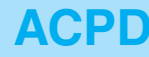

$8,4499-4559,2008$

ACE water vapour validation

M. R. Carleer et al.

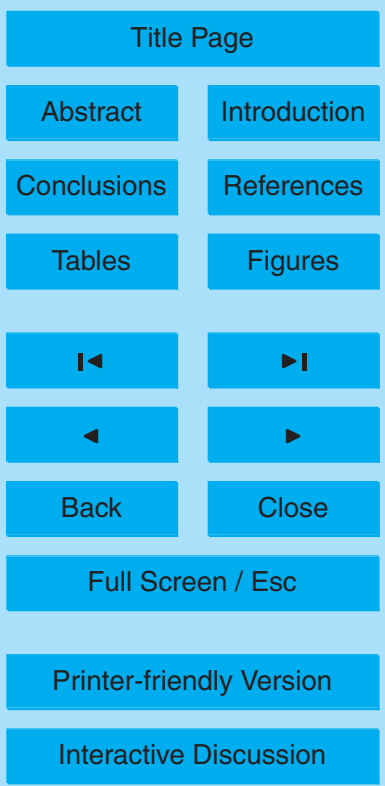

EGU 
Oltmans, S. J., Vömel, , H., Hofmann, D. J., Rosenlof, K. H., and Kley, D.: The increase in stratospheric water vapour from balloon-borne frostpoint hygrometer measurements at Washington, D.C. and Boulder, Colorado, Geophys. Res. Lett., 27(21), 3453-3456, 2000.

Pumphrey, H. C., Clark, H. L., and Harwood, R. S.: Lower stratospheric water vapor measured by UARS MLS, Geophys. Res. Lett., 27(12), 1691-1694, doi:10.1029/1999GL011339, 2000.

Randel, W. J., Wu, F., Oltmans, S. J., Rosenlof, K. H., and Nedoluha, G. E.: Interannual changes of stratospheric water vapour and correlations with tropical tropopause temperatures, J. Atmos. Sci., 61(17), 2133-2148, 2004.

Reber, C. A., Trevathan, C. E., McNeal, R. J., and Luther, M. R.: The Upper Atmosphere Research Satellite (UARS) Mission, J. Geophys. Res., 98(D6), 10 643-10 647, 1993.

Rosenlof, K. H., Chiou, E.-W., Chu, W. P., Johnson, D. G., Kelly, K. K., Michelsen, H. A., Nedoluha, G. E., Remsberg, E. E., Toon, G. C., and McCormick, M. P.: Stratospheric water vapour increases over the past half-century, Geophys. Res. Lett., 28(7), 1195-1198,2001.

Russell III, J. M., Gordley, L. L., Park, J. H., Drayson, S. R., Hesketh, W. D., Cicerone, R.

15 J., Tuck, A. F., Frederick, J. E., Harries, J. E., and Crutzen, P. J.: The Halogen Occultation Experiment, J. Geophys. Res., 98(D6), 10 777-10 797, doi:10.1029/93JD00799, 1993.

Santee, M. L., Manney, G. L., Livesey, N. J., Froidevaux, L., MacKenzie, I. A., Pumphrey, H. C., Read, W. G., Schwartz, M. J., Waters, J. W., and Harwood, R. S.: Polar processing and development of the 2004 Antarctic ozone hole: First results from MLS on Aura, Geophys.

20 Res. Lett., 32(12), L12817, doi:10.1029/2005GL022582, 2005.

Seele, C. and Hartogh, P.: Water vapour of the polar middle atmosphere: annual variation and summer mesosphere conditions as observed by ground-based microwave spectroscopy. Geophys. Res. Lett., 25, 2133-2136, 1999.

Sherwood, S. C. and Dessler, A. E.: On the control of stratospheric humidity, Geophys. Res. Lett., 27, 2513-2516, 2000.

Sica, R. J., Sargoytchev, S., Argall, P. S., Borra, E. F., Girard, L., Sparrow, C. T., and Flatt, S.: Lidar measurements taken with a large-aperture liquid mirror. 1. Rayleigh-scatter system, Appl. Optics, 34, 6925-6936, 1995.

Sica, R. J., Izawa, M. R. M., Walker, K. A., Boone, C., Petelina, S. V., Argall, P. S., Bernath, P., 30 Burns, G. B., Catoire, V., Collins, R. L., Daffer, W. H., De Clercq, C., Fan, Z. Y., Firanski, B. J., French, W. J. R., Gerard, P., Gerding, M., Granville, J., Innis, J. L., Keckhut, P., Kerzenmacher, T., Klekociuk, A. R., Lambert, J. C., Llewellyn, E. J., Manney, G. L., McDermid, I. S., Mizutani, K., Murayama, Y., Piccolo, C., Robert, C., Steinbrecht, W., Strawbridge, K. B.,

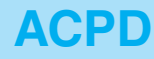

8, 4499-4559, 2008

ACE water vapour validation

M. R. Carleer et al.

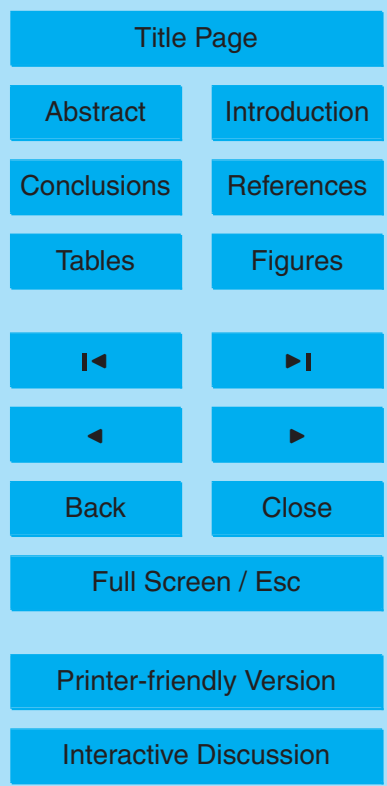


Strong, K., Stubi, R., and Thurairajah, B.: Validation of the Atmospheric Chemistry Experiment (ACE) version 2.2 Temperature Using Ground-based and Space-borne Measurements, Atmos. Chem. Phys., 8, 35-62, 2008,

http://www.atmos-chem-phys.net/8/35/2008/.

5 Sonnemann, G. R., Grygalashvyly, M., and Berger, U.: Autocatalytic water vapor production as a source of large mixing ratios within the middle to upper mesosphere, J. Geophys. Res., 110, D15303, doi:10.1029/2004JD005593, 2005.

Summers, M. E., Conway, R. R., Siskind, D. E., Stevens, M. H., Offermann, D., Riese, M., Preusse, P., Strobel, D. F., and Russell III, J. M.: Implications of satellite $\mathrm{OH}$ observations for middle atmospheric $\mathrm{H} 2 \mathrm{O}$ and ozone, Science, 277, 1967-1970, 1997.

Summers, M. E., Conway, R. R., Englert, C. R., Siskind, D. E., Stevens, M. H., Russell III, J. M., Gordley, L. L., and McHugh, M. J.: Discovery of a water vapor layer in the Arctic summer mesosphere: implications for polar mesospheric clouds, Geophys Res. Lett., 28(18), 36013604, 2001.

Taha, G., Thomason, L. W., and Burton, S. P.: Comparison of Stratospheric Aerosol and Gas Experiment (SAGE) II version 6.2 water vapour with balloon-borne and space-based instruments, J. Geophys. Res., 109, D18313, doi:10.1029/2004JD004859, 2004

Taylor, F. W., Barnett, J. J., Colbeck, I., Jones, R. L., Rodgers, C. D., Wale M. J., and Williamson, E. J.: Performance and early results from the Stratospheric and Mesospheric Sounder (SAMS) on Nimbus 7, Adv. Space Res., 1(4), 261-265, doi:10.1016/0273-1177(81)90068-5, 1981.

Taylor, F. W., Rodgers, C. D., Whitney, J. G., Werrett, S. T., Barnett, J. J., Peskett, G. D., Venters, P., Ballard, J., Palmer, C. W. P., Knight, R. J., Morris, P., Nightingale, T., and Dudhia, A.: Remote sensing of the atmospheric structure and composition by pressure modulator radiometry from space: the ISAMS experiment on UARS, J. Geophys. Res., 98(D6), 1079910814, doi:10.1029/92JD03029, 1993.

Thomason, L. W., Burton, S. P., Iyer, N., Zawodny, J. M., and Anderson, J.: A revised water vapour product for the Stratospheric Aerosol and Gas Experiment (SAGE II) version 6.2 data set, J. Geophys. Res., 109, D06312, doi:10.1029/2003JD004465,2004.

so Urban, J., Lautié , N., Murtagh, D., Eriksson, P., Kasai, Y., Lossow, S., Dupuy, E., de La Noë, J., Frisk, U., Olberg, M., Le Flochmoën, E., and Ricaud, P.: Global observations of middle atmospheric water vapour by the Odin satellite: an overview, Planet. Space Sci., 55, 10931102, 2007.

ACE water vapour validation

M. R. Carleer et al.

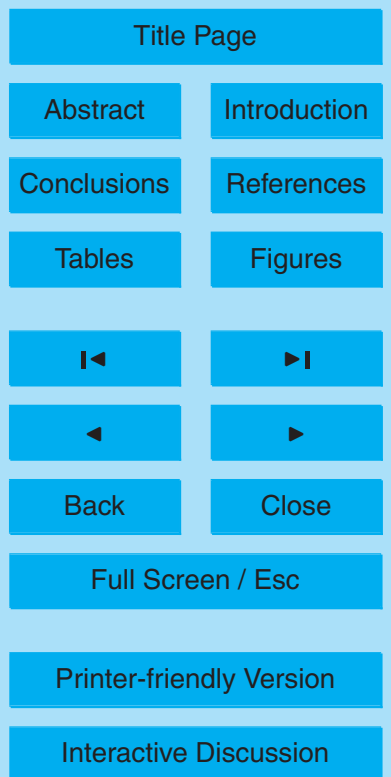

EGU 
Vömel, H., David, D. E., and Smith, K.: Accuracy of tropospheric and stratospheric water vapour measurements by the cryogenic frost point hygrometer: Instrumental details and observations, J. Geophys. Res., 112, D08305, doi:10.1029/2006JD007224, 2007.

von Clarmann, T., Glatthor, N., Grabowski, U., Höpfner, M., Kellmann, S., Kiefer, M., Linden, A., Mengistu Tsidu, G., Milz, M., Steck, T., Stiller, G. P., Wang, D. Y., Fischer, H., Funke, B., Gil-López, S., and López-Puertas, M.: Retrieval of temperature and tangent altitude pointing from limb emission spectra recorded from space by the Michelson Interferometer for Passive Atmospheric Sounding (MIPAS), J. Geophys. Res., 108(D23), 4736, doi:10.1029/2003JD003602, 2003.

10 von Zahn, U. and Berger, U.: Persistent ice cloud in the midsummer upper mesosphere at high latitudes: three-dimensional modeling and cloud interactions with ambient water vapour. J. Geophys. Res., 108(D8), doi:10.1029/2002JD002409, 2003.

Waters, J. W., Read, W. G., Froidevaux, L., Jarnot, R. F., Cofield, R. E., Flower, D. A., Lau, G. K., Pickett, H. M., Santee, M. L., Wu, D. L., Boyles, M. A., Burke, J. R., Lay, R. R., Loo, M. S., Livesey, N. J., Lungu, T. A., Manney, G. L., Nakamura, L. L., Perun, V. S., Ridenoure, B. P., Shippony, Z., Siegel, P. H., and Thurstans, R. P.: The UARS and EOS Microwave Limb Sounder (MLS) Experiments, J. Atmos. Sci., 56(2), 194-218, doi:10.1175/1520-0469, 1999.

\section{ACPD}

$8,4499-4559,2008$

\section{ACE water vapour} validation

\section{R. Carleer et al.}

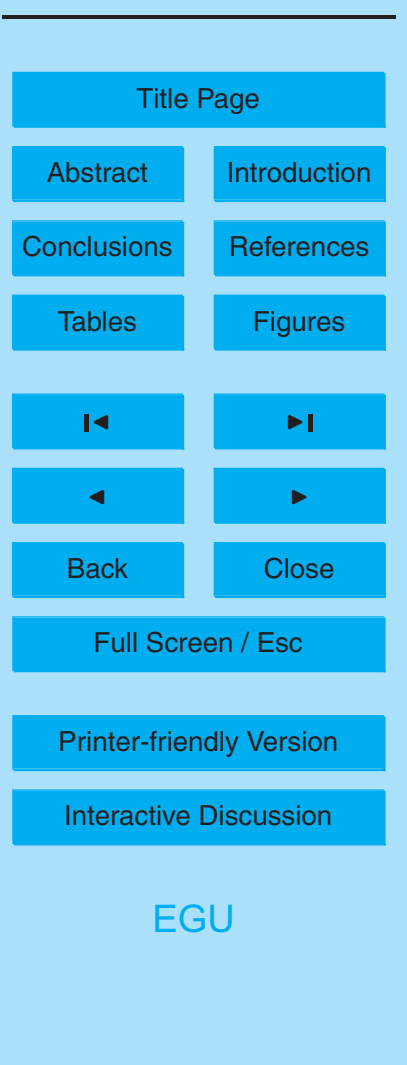




\section{ACPD}

$8,4499-4559,2008$

\section{ACE water vapour} validation

M. R. Carleer et al.

Table 1. Spatial-temporal coincidence of ACE-FTS overpasses with the Purple Crow Lidar. The distance in the $3 \mathrm{rd}$ column is to the $10 \mathrm{~km}$ point of the ACE-FTS measurement. The time in the 4th column is the time between the ACE-FTS overpass and the nearest PCL measurement.

\begin{tabular}{cccc}
\hline Coincidence & ACE Occultation & Distance $(\mathrm{km})$ & Time $(\mathrm{h}: \mathrm{min})$ \\
\hline 30 June 2005 & ss10130 & 776 & $0: 24$ \\
1 Sep 2005 & sr11060 & 228 & $1: 01$ \\
2 Sep 2005 & sr11075 & 854 & $1: 14$ \\
5 May 2006 & sr14686 & 925 & $1: 31$ \\
\hline
\end{tabular}

\section{Title Page}

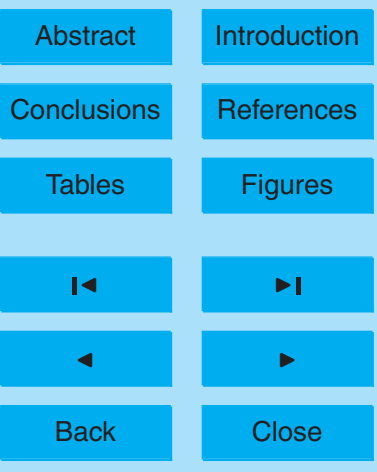

Full Screen / Esc

Printer-friendly Version

Interactive Discussion 


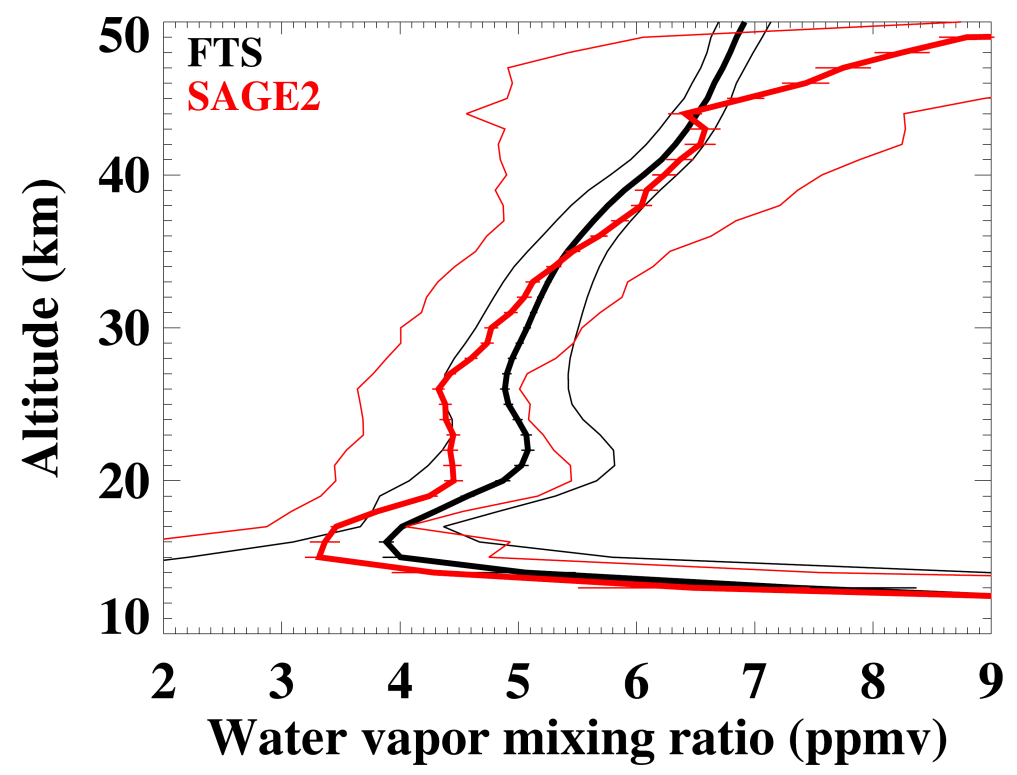

\section{ACE water vapour} validation

M. R. Carleer et al.

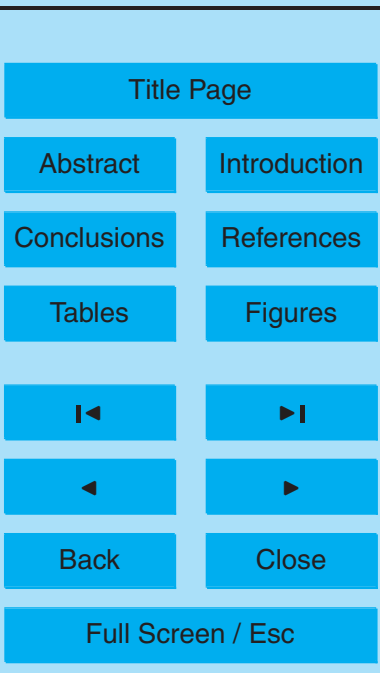
and SAGE II (red). Thin lines are the profiles of standard deviations $(1-\sigma)$ of the distributions, while error bars (often too small to be seen) represent the uncertainty in the mean (1- $\sigma$ divided by the square root of the number of comparisons). 


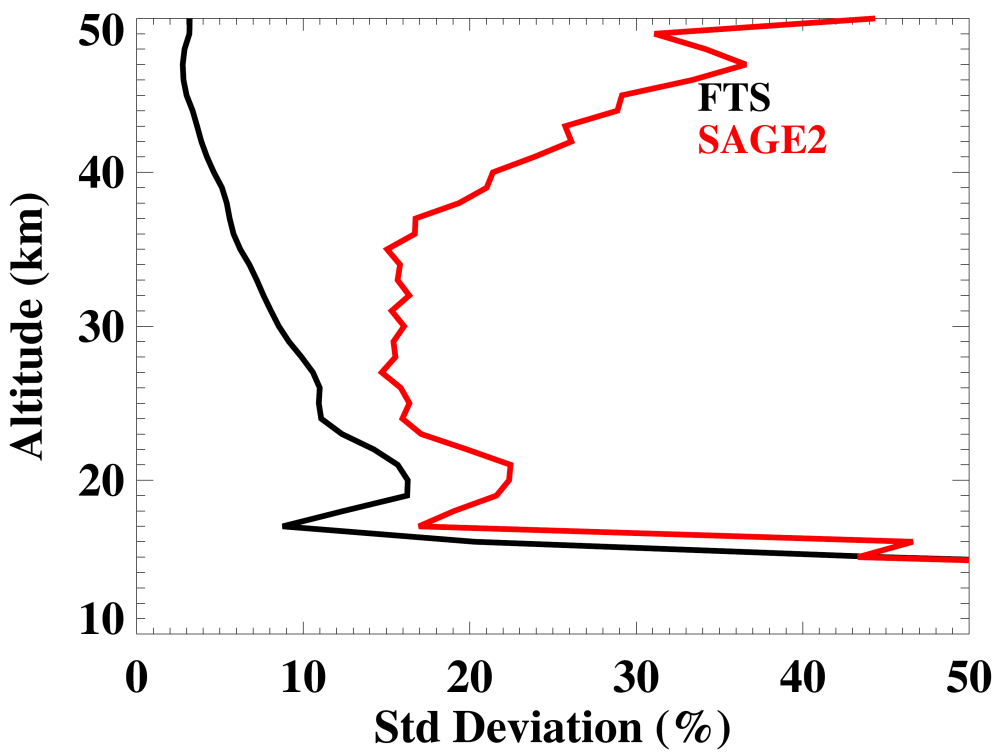

Fig. 2. Standard deviations of the distributions, $1-\sigma$, relative to the mean $\mathrm{H}_{2} \mathrm{O}$ VMR at each altitude, for all coincident events, for ACE-FTS (black) and SAGE II (red).

\section{ACPD}

$8,4499-4559,2008$

\section{ACE water vapour} validation

M. R. Carleer et al.

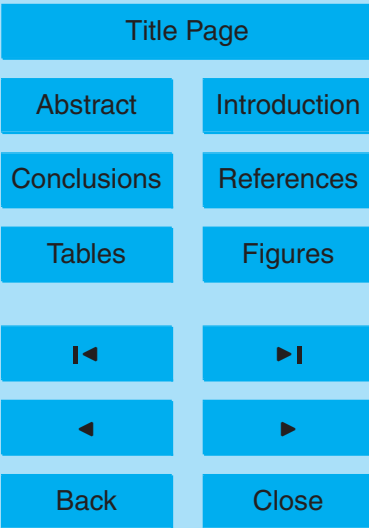

Full Screen / Esc

Printer-friendly Version

Interactive Discussion 


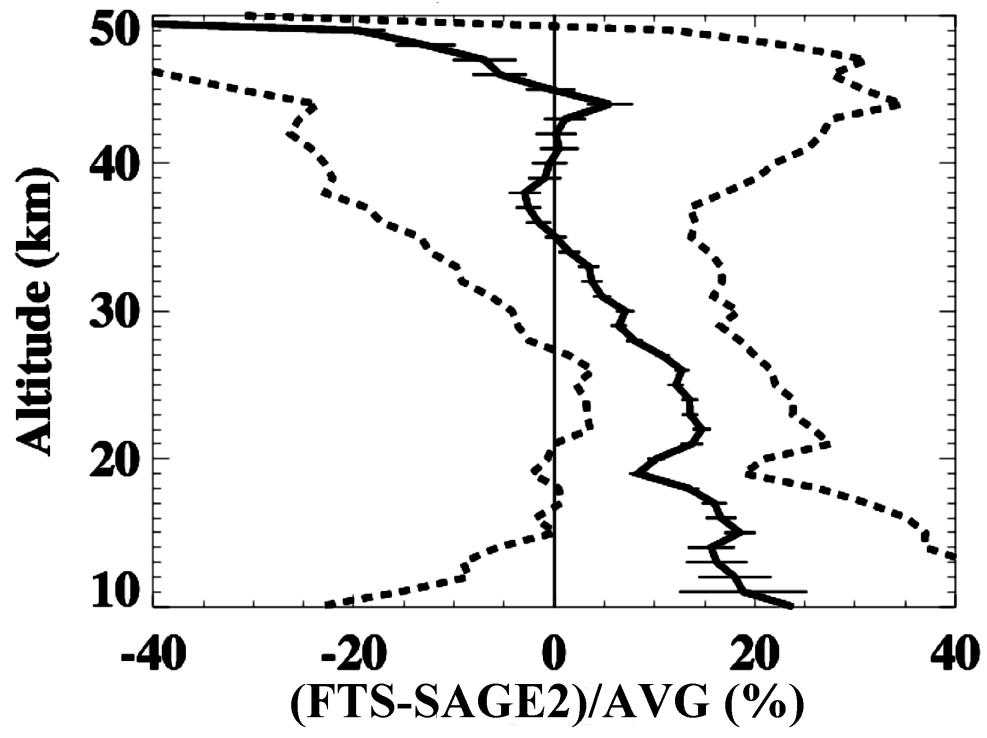

Fig. 3. Average percent differences (solid line) between ACE-FTS and SAGE II relative to the average of the two instruments, for all coincidences. Dashed lines represent the standard deviation of the distribution of differences while error bars represent the uncertainty in the mean difference.
ACPD

$8,4499-4559,2008$

\section{ACE water vapour} validation

M. R. Carleer et al.

Title Page

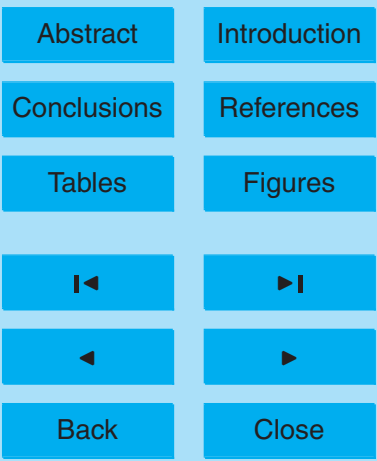

Full Screen / Esc

Printer-friendly Version

Interactive Discussion 


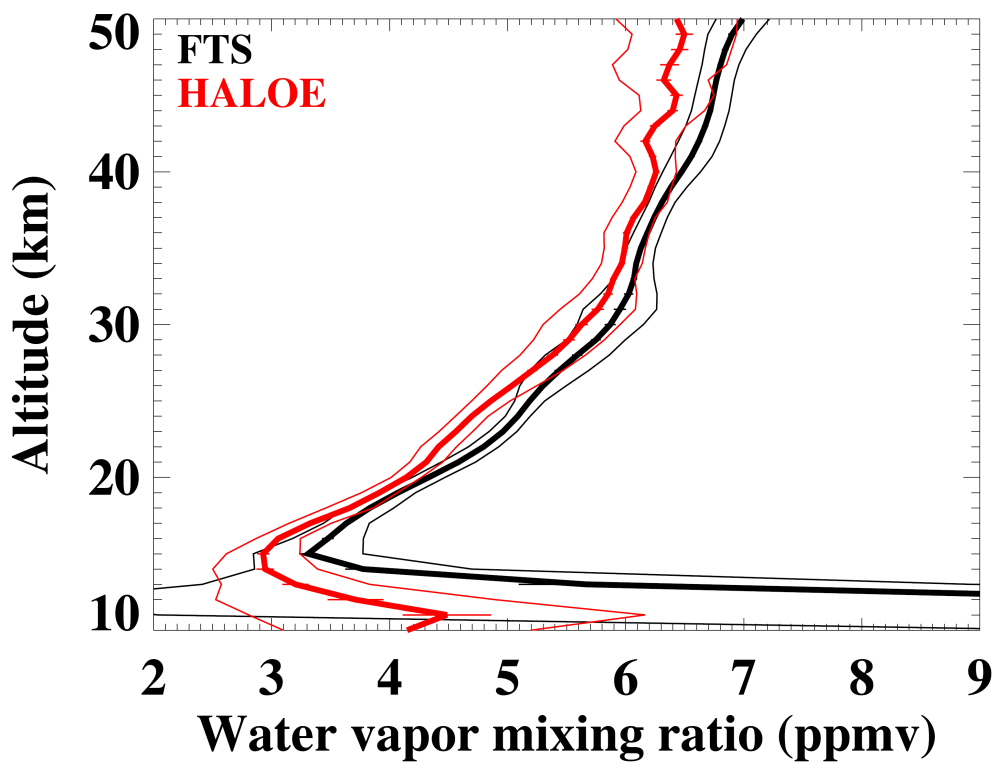

\section{ACE water vapour} validation

M. R. Carleer et al.

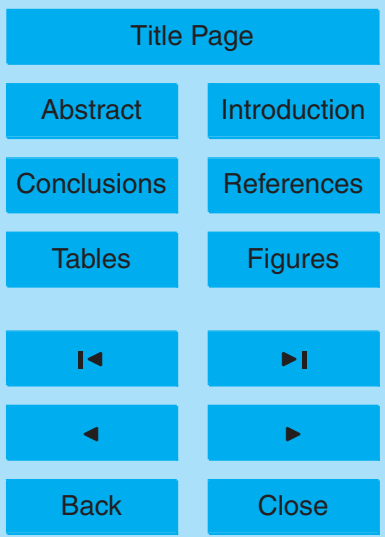

Full Screen / Esc

Fig. 4. Same as Fig. 1, but for HALOE.

Printer-friendly Version

Interactive Discussion 


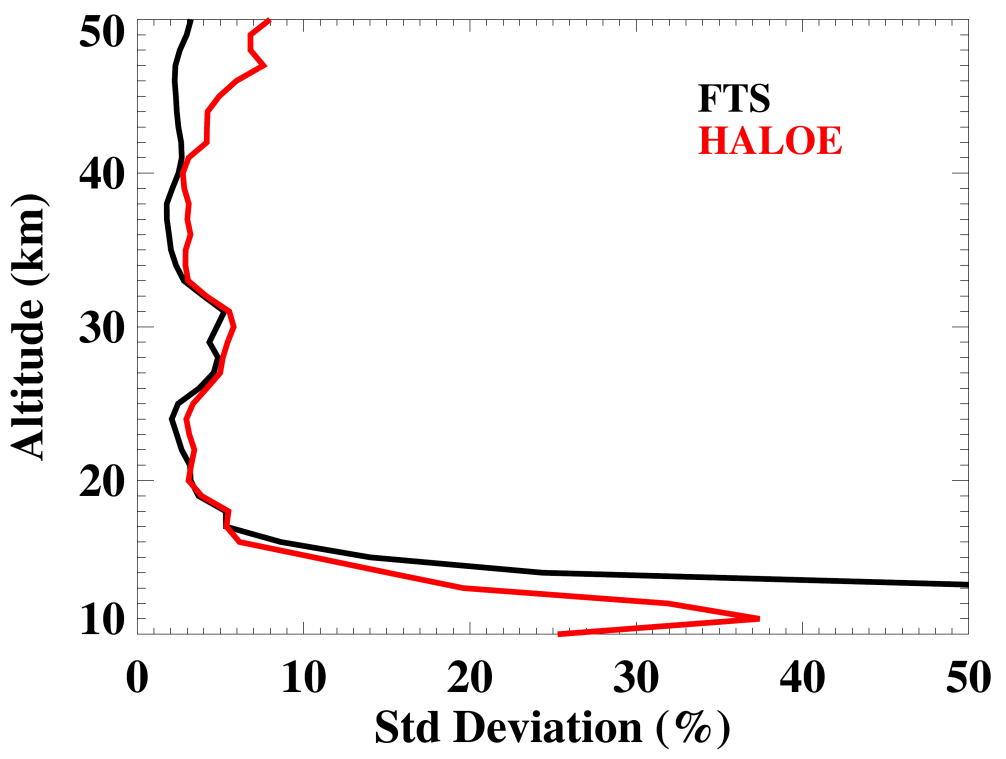

8, 4499-4559, 2008

ACE water vapour validation

M. R. Carleer et al.

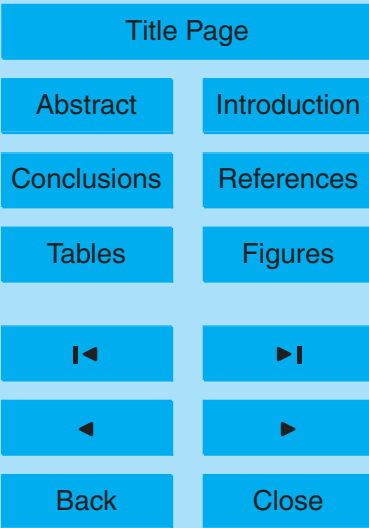

Full Screen / Esc

Fig. 5. Same as Fig. 2, but for HALOE.

Printer-friendly Version

Interactive Discussion 


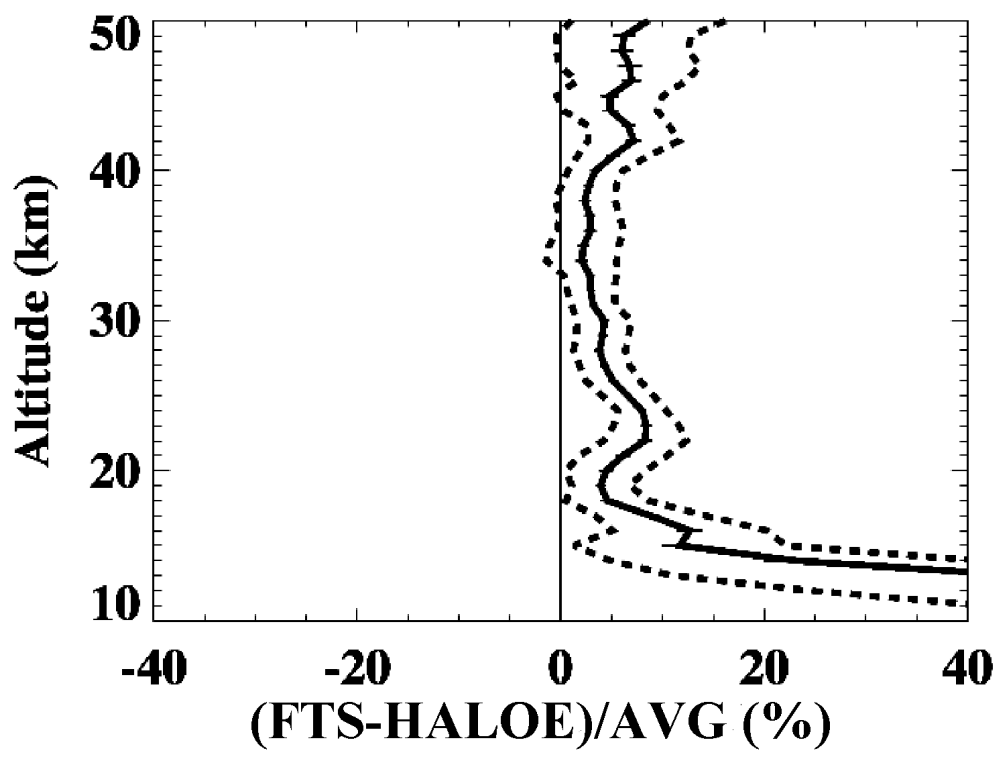

Fig. 6. Same as Fig. 3, but for HALOE.

\section{ACPD}

8, 4499-4559, 2008

\section{ACE water vapour} validation

M. R. Carleer et al.

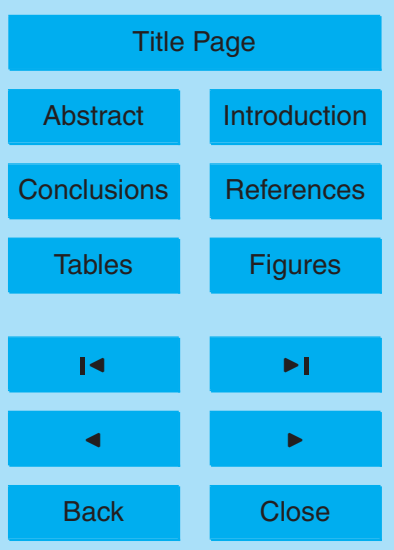

Full Screen / Esc

Printer-friendly Version

Interactive Discussion 


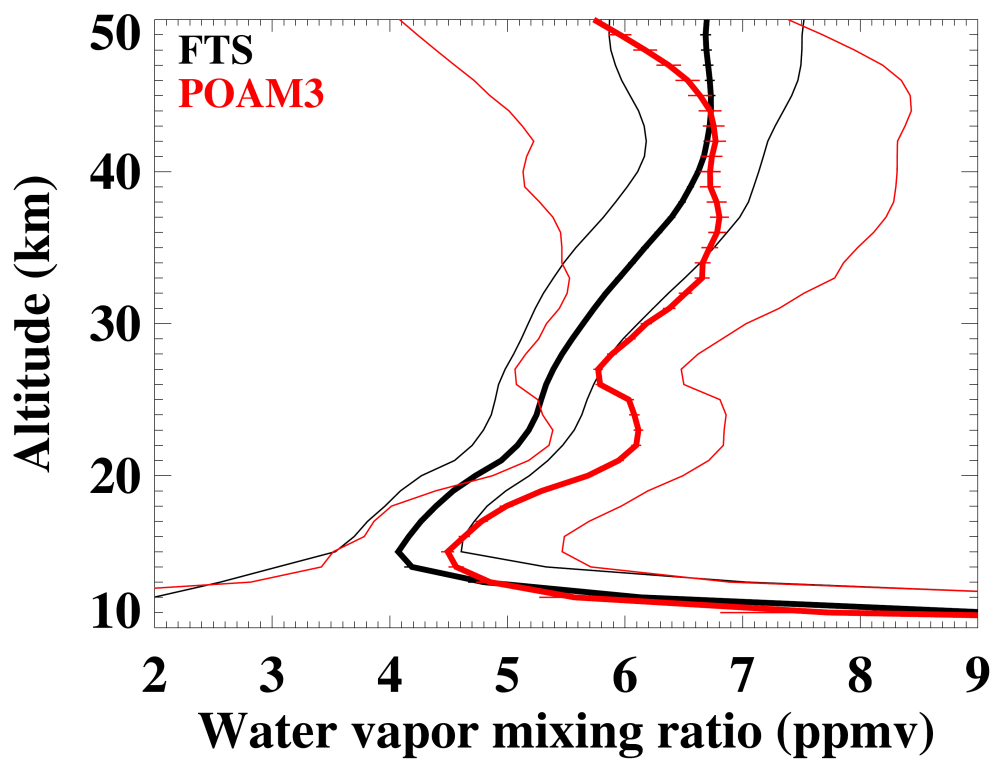

8, 4499-4559, 2008

ACE water vapour validation

M. R. Carleer et al.

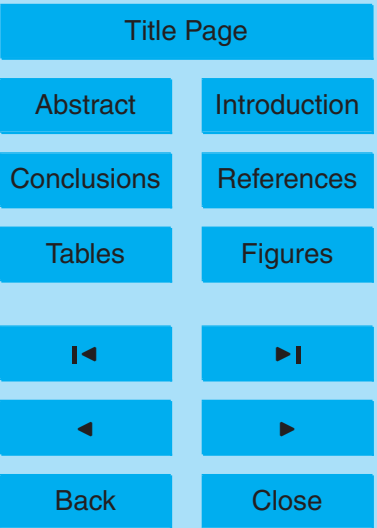

Full Screen / Esc

Fig. 7. Same as Fig. 1, but for POAM III.

Printer-friendly Version

Interactive Discussion 


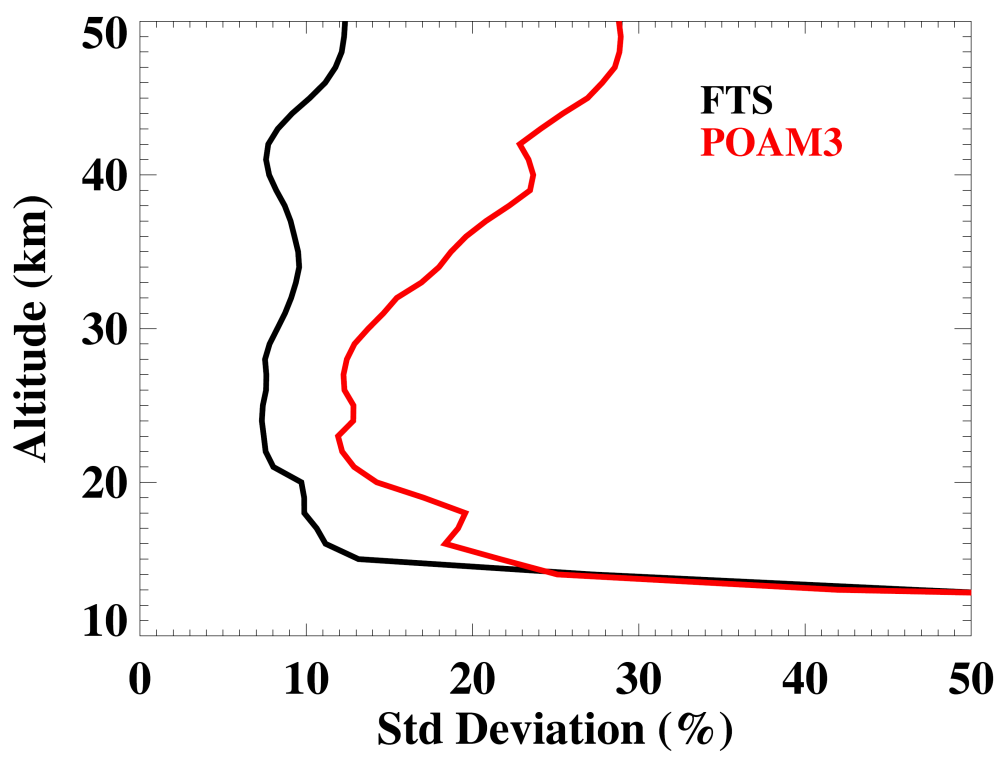

\section{ACE water vapour} validation

M. R. Carleer et al.

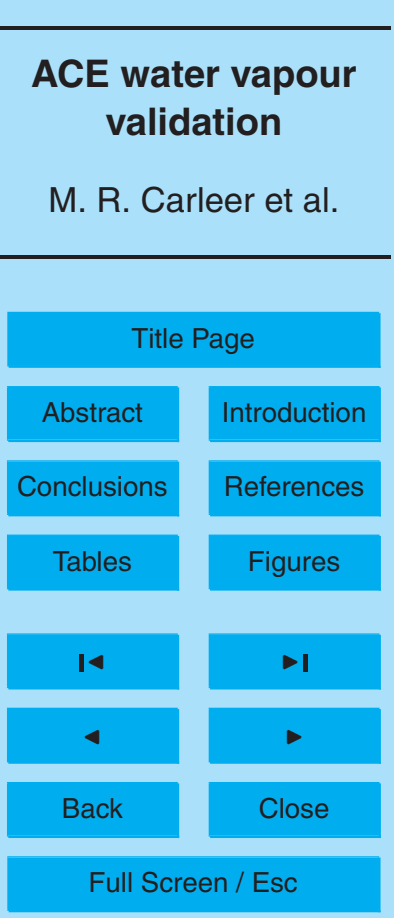

Fig. 8. Same as Fig. 2, but for POAM III.

8, 4499-4559, 2008

Full Screen / Esc

Printer-friendly Version

Interactive Discussion 


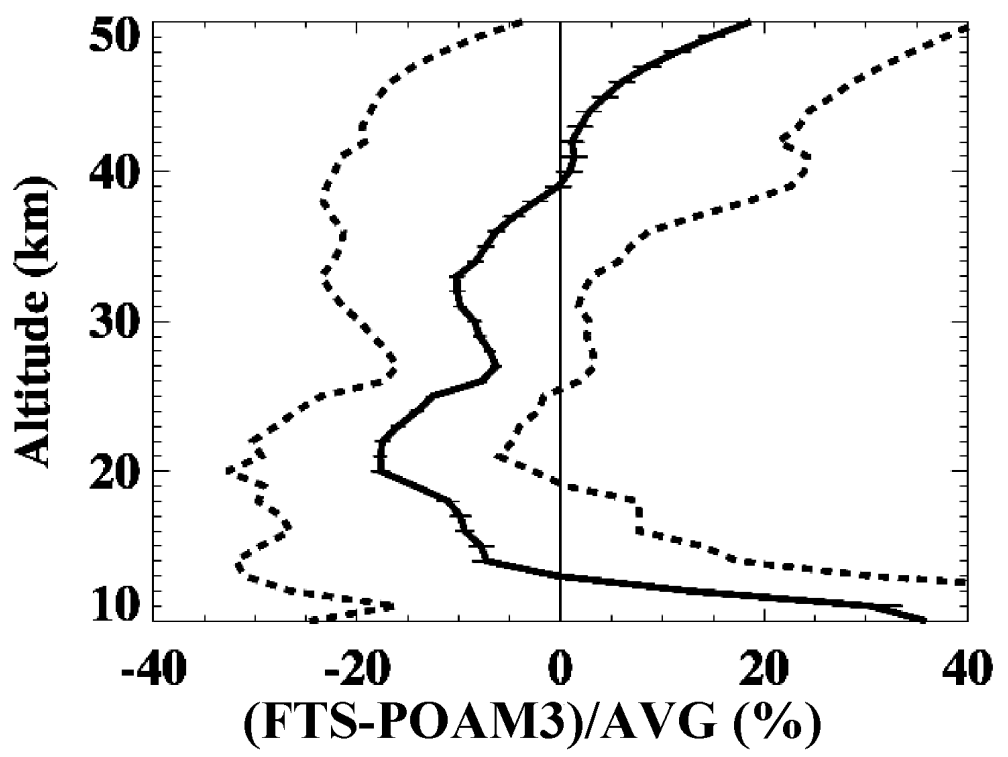

Fig. 9. Same as Fig. 3, but for POAM III.

\section{ACPD}

8, 4499-4559, 2008

\section{ACE water vapour} validation

M. R. Carleer et al.

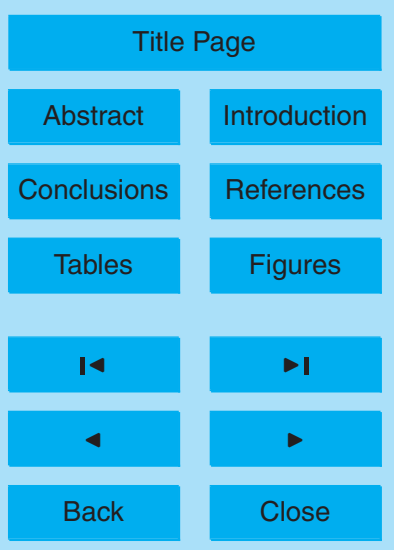

Full Screen / Esc

Printer-friendly Version

Interactive Discussion 


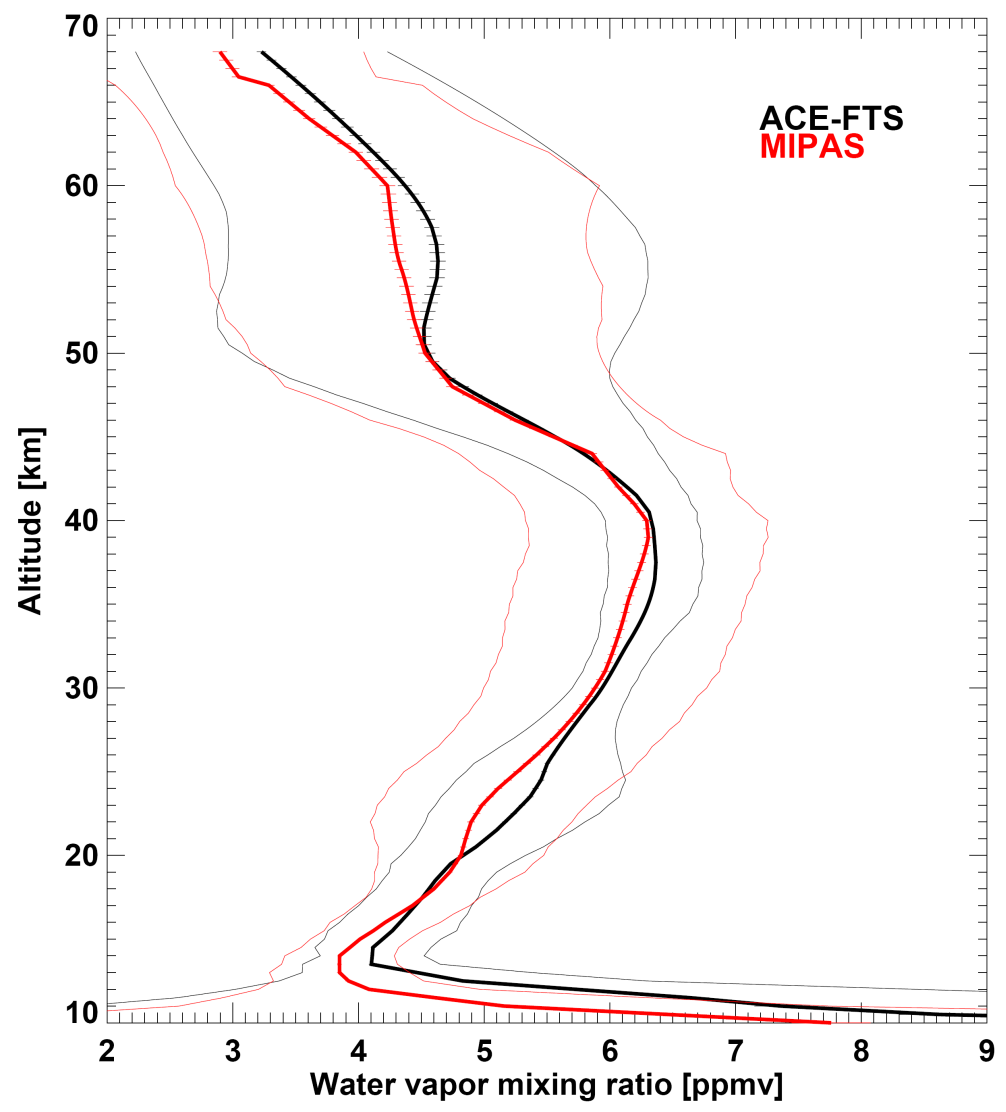

8, 4499-4559, 2008

\section{ACE water vapour} validation

M. R. Carleer et al.

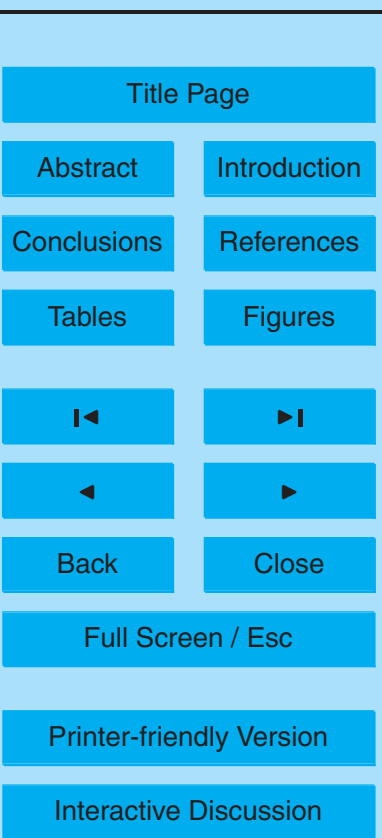

Fig. 10. Same as Fig. 1, but for MIPAS. 


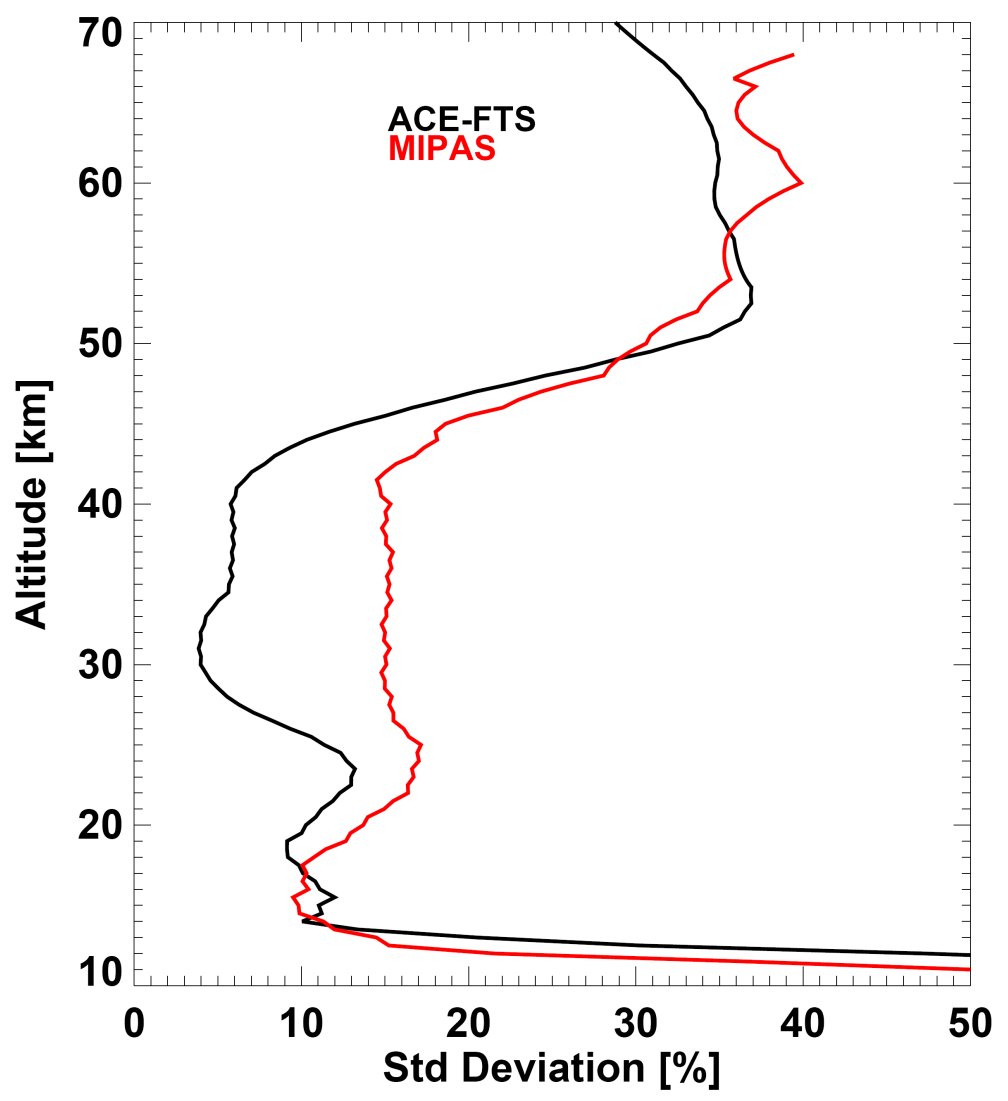

8, 4499-4559, 2008

ACE water vapour validation

M. R. Carleer et al.

Title Page

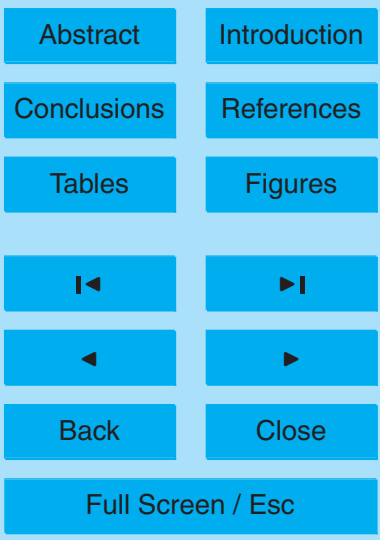

Printer-friendly Version

Interactive Discussion 


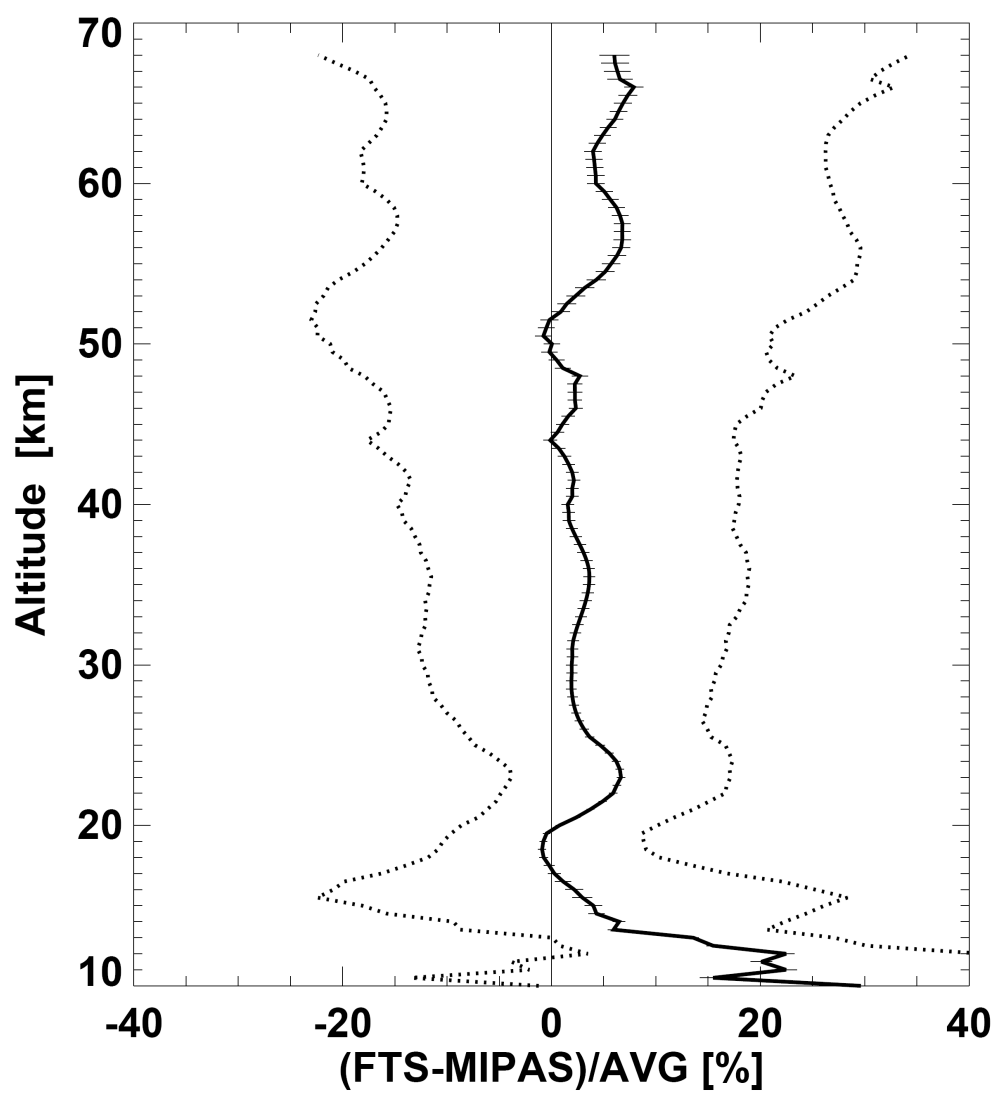

8, 4499-4559, 2008

ACE water vapour validation

M. R. Carleer et al.

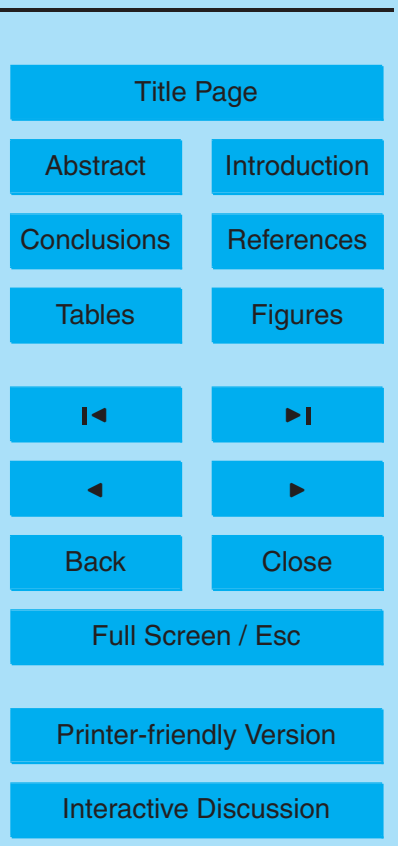

Fig. 12. Same as Fig. 3, but for MIPAS. 


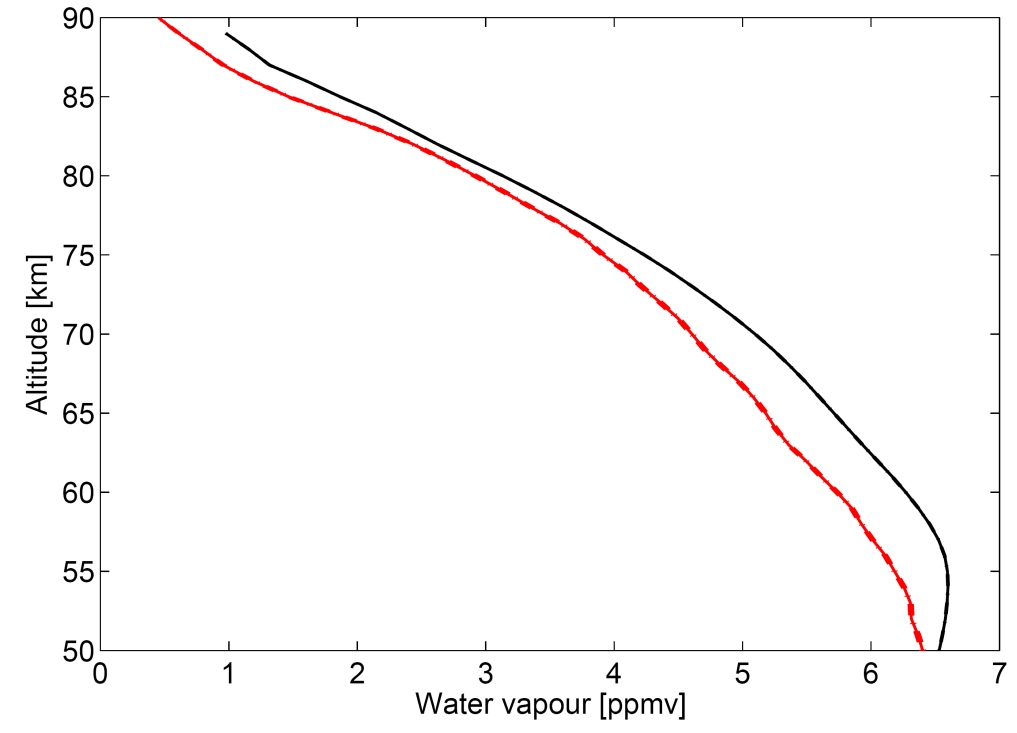

Fig. 13. Average profiles for all 2033 coincident measurements of ACE-FTS (black) and OdinSMR (red).
ACPD

$8,4499-4559,2008$

\section{ACE water vapour} validation

M. R. Carleer et al.

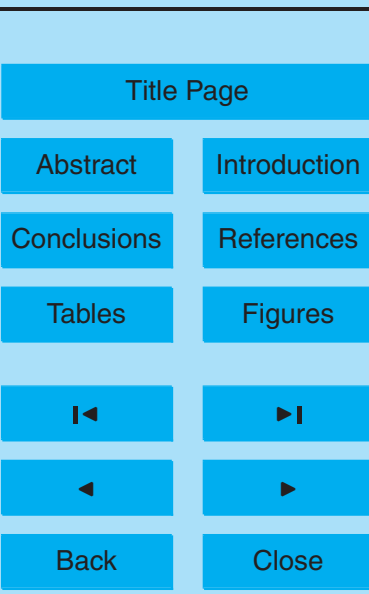

Full Screen / Esc

Printer-friendly Version

Interactive Discussion 


\section{ACPD}

$8,4499-4559,2008$

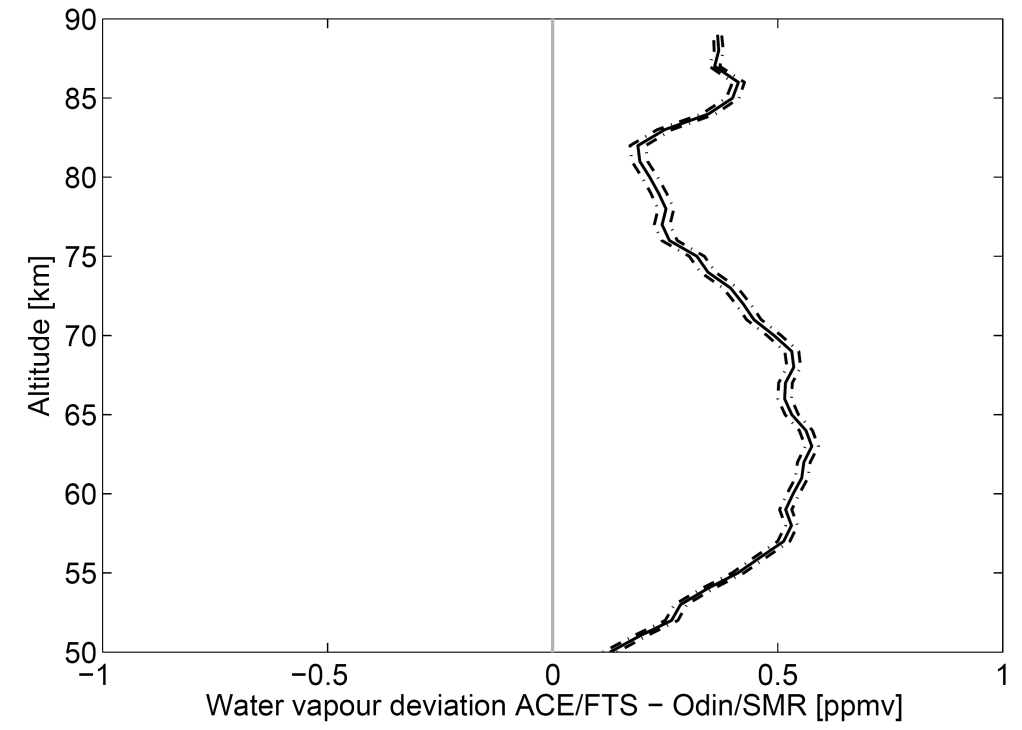

\section{ACE water vapour} validation

M. R. Carleer et al.

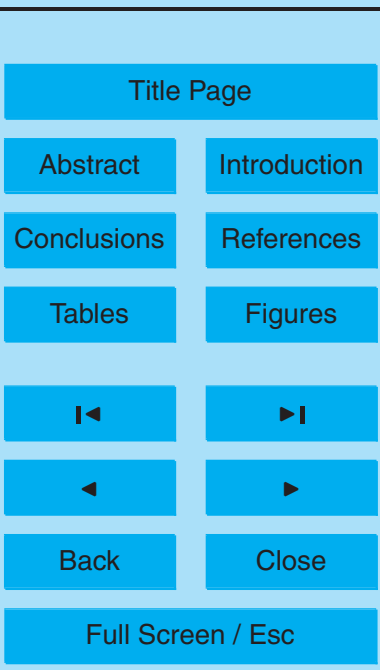

Fig. 14. Difference between ACE-FTS and Odin-SMR average profiles. Dashed lines represent Full Screen / Esc the uncertainty of the distribution of differences. 


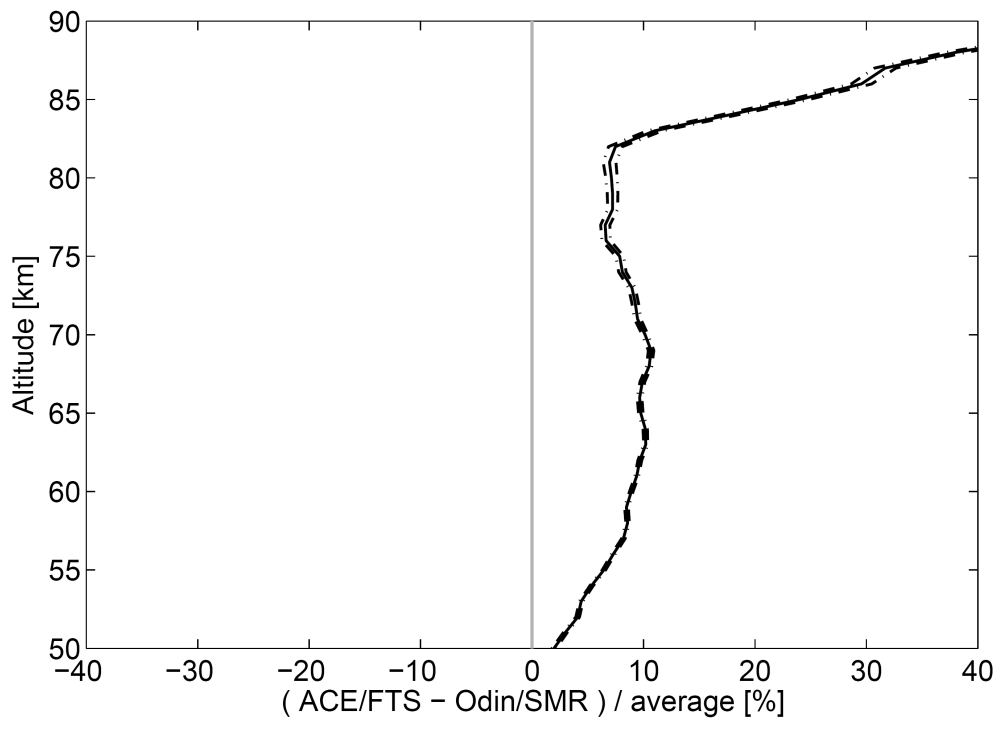

Fig. 15. Average percent differences (solid) between ACE-FTS and Odin-SMR relative to the average, for all coincidences. Dashed lines represent the uncertainty of the distribution of percent differences.
ACPD

$8,4499-4559,2008$

ACE water vapour validation

M. R. Carleer et al.

Title Page

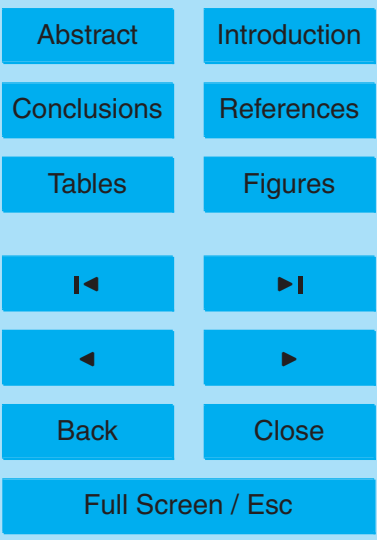

Printer-friendly Version

Interactive Discussion 


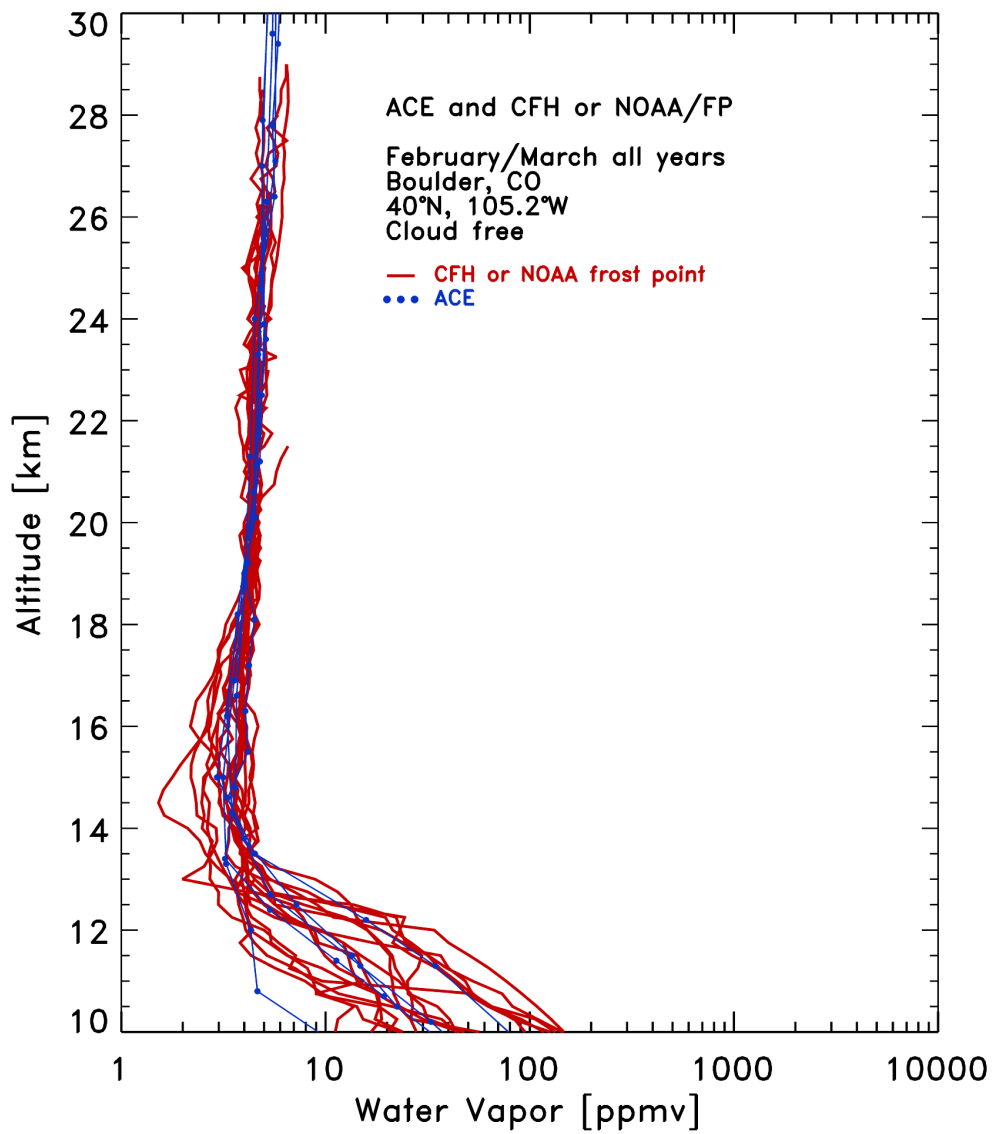

Fig. 16. ACE-FTS (blue) and NOAA/FP (red) profiles for the February/March periods for all years from 2004 to 2006, above Boulder, Colorado (40 N, 105.2 W).

\section{ACPD}

$8,4499-4559,2008$

\section{ACE water vapour} validation

M. R. Carleer et al.

Title Page

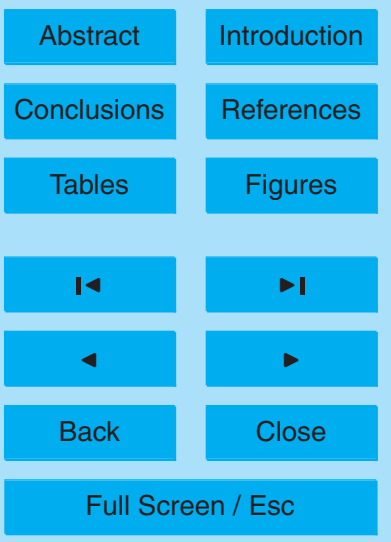

Printer-friendly Version

Interactive Discussion 


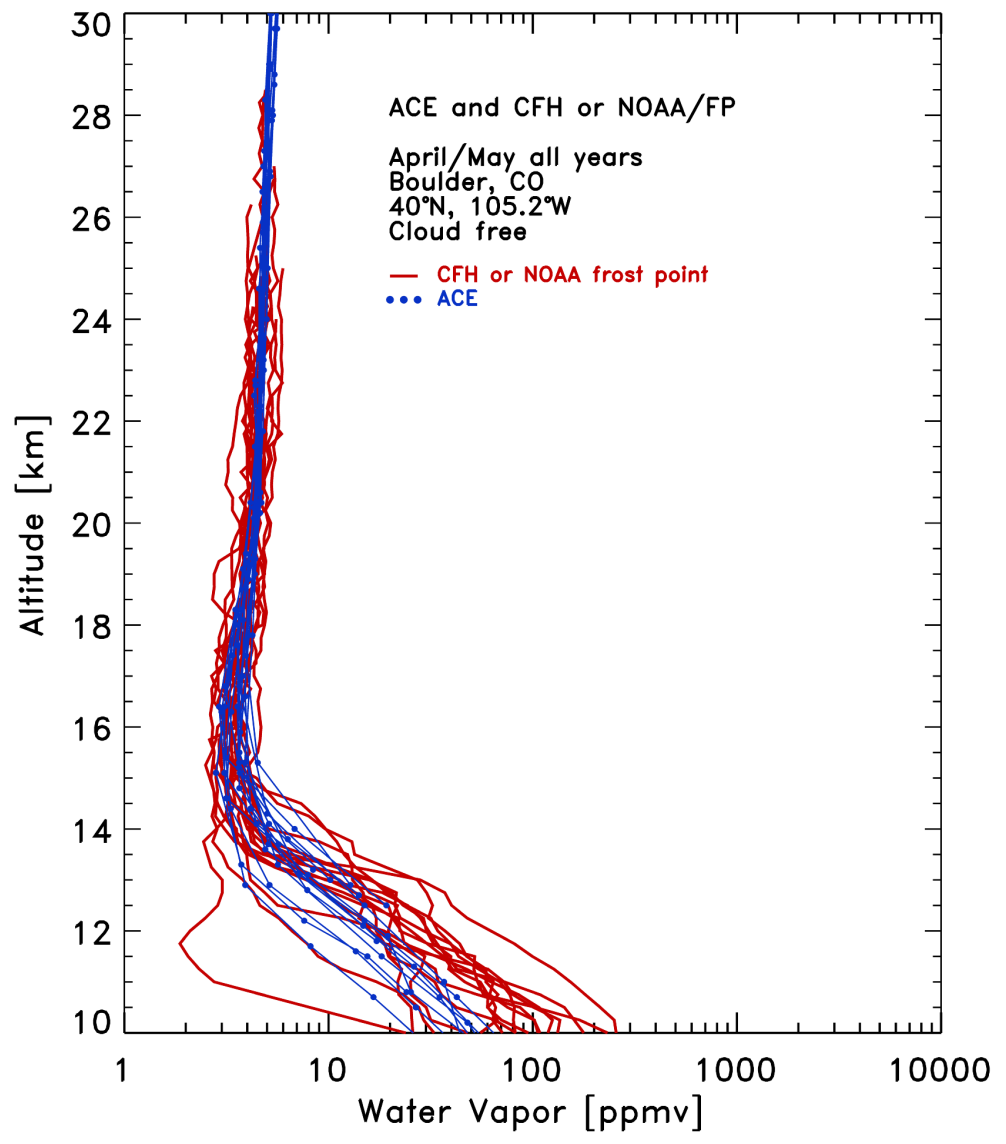

8, 4499-4559, 2008

\section{ACE water vapour} validation

M. R. Carleer et al.

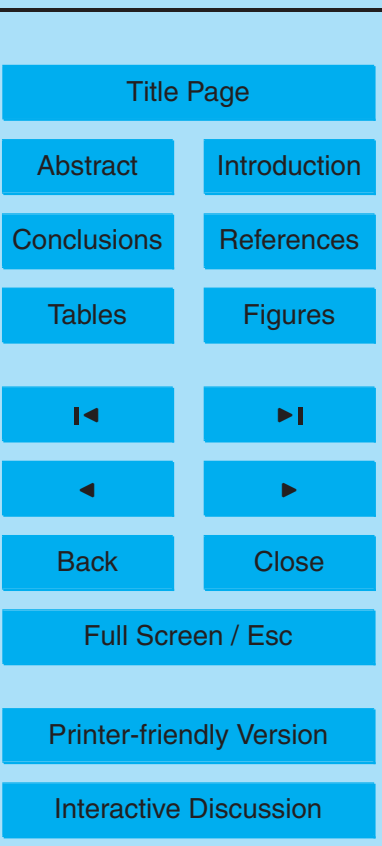

Fig. 17. Same as Fig. 16 for April/May. 


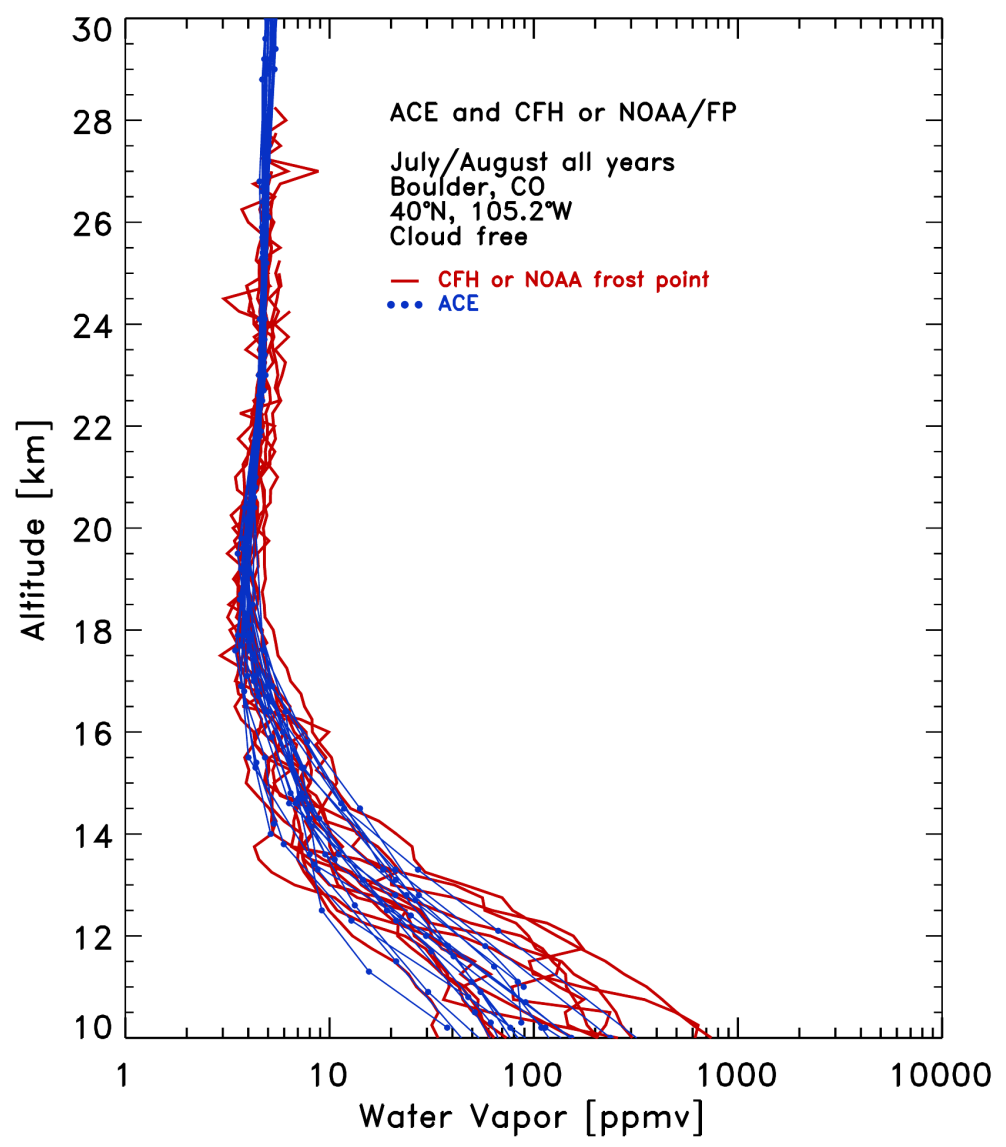

8, 4499-4559, 2008

ACE water vapour validation

M. R. Carleer et al.

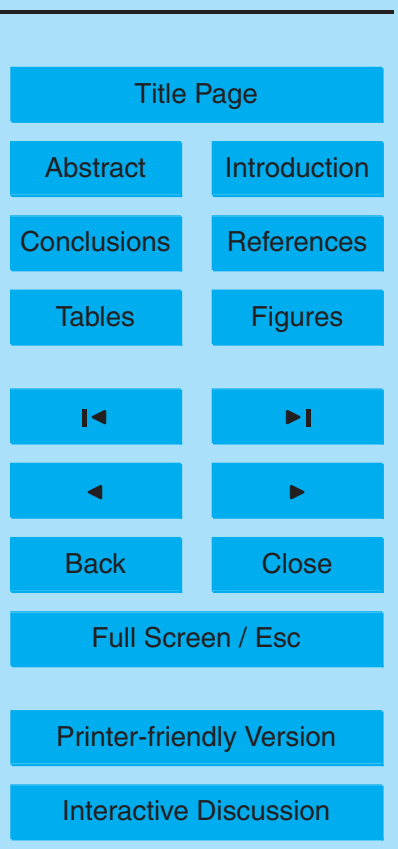

Fig. 18. Same as Fig. 16 for July/August. 


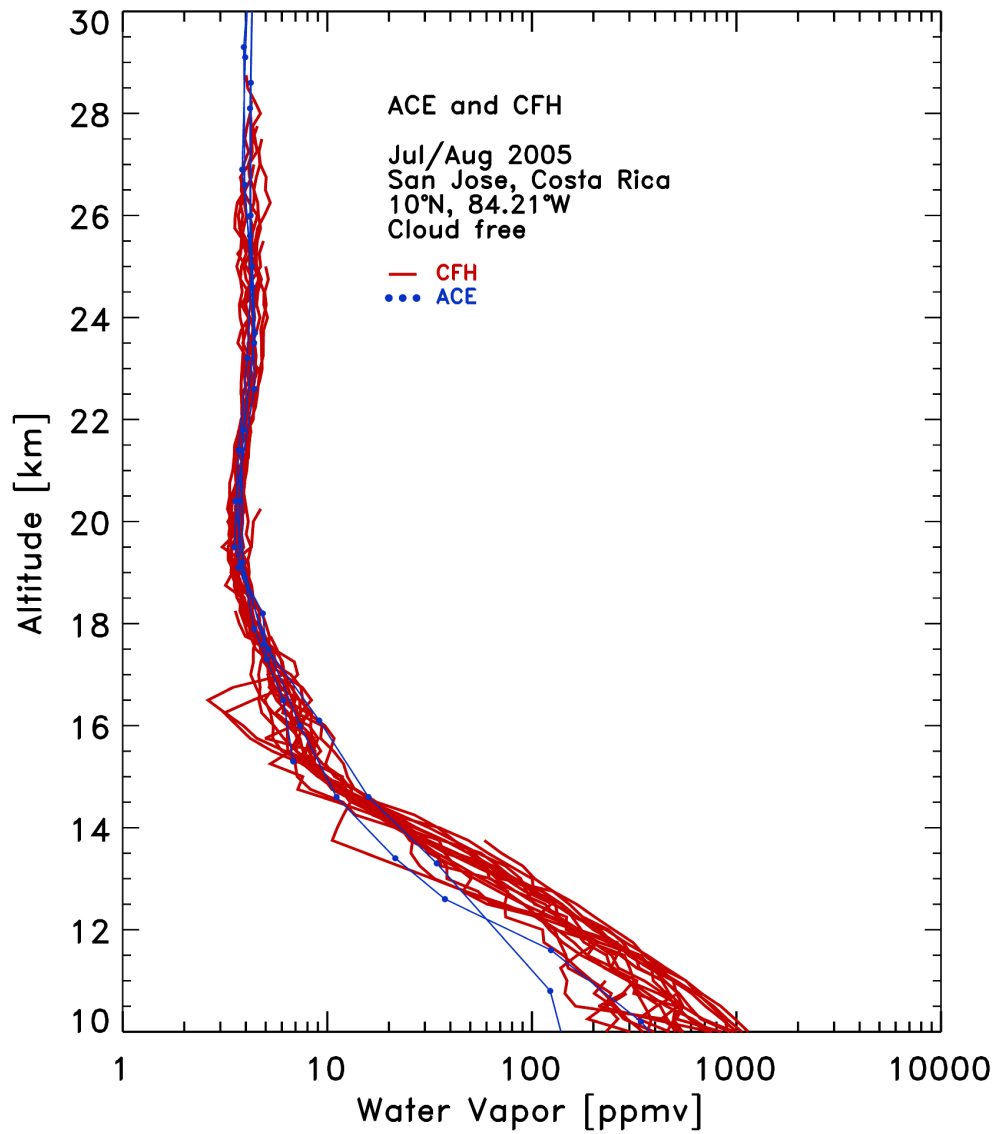

Fig. 19. ACE-FTS (blue) and CFH (red) profiles for the July/August 2005 period, above San Jose, Costa Rica (10 N, 84.21 W).

\section{ACPD}

$8,4499-4559,2008$

\section{ACE water vapour} validation

M. R. Carleer et al.

\section{Title Page}

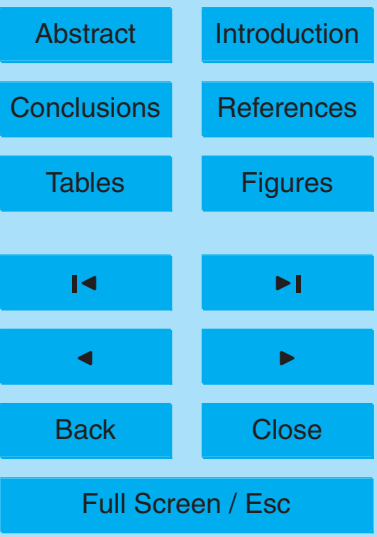

Printer-friendly Version

Interactive Discussion 


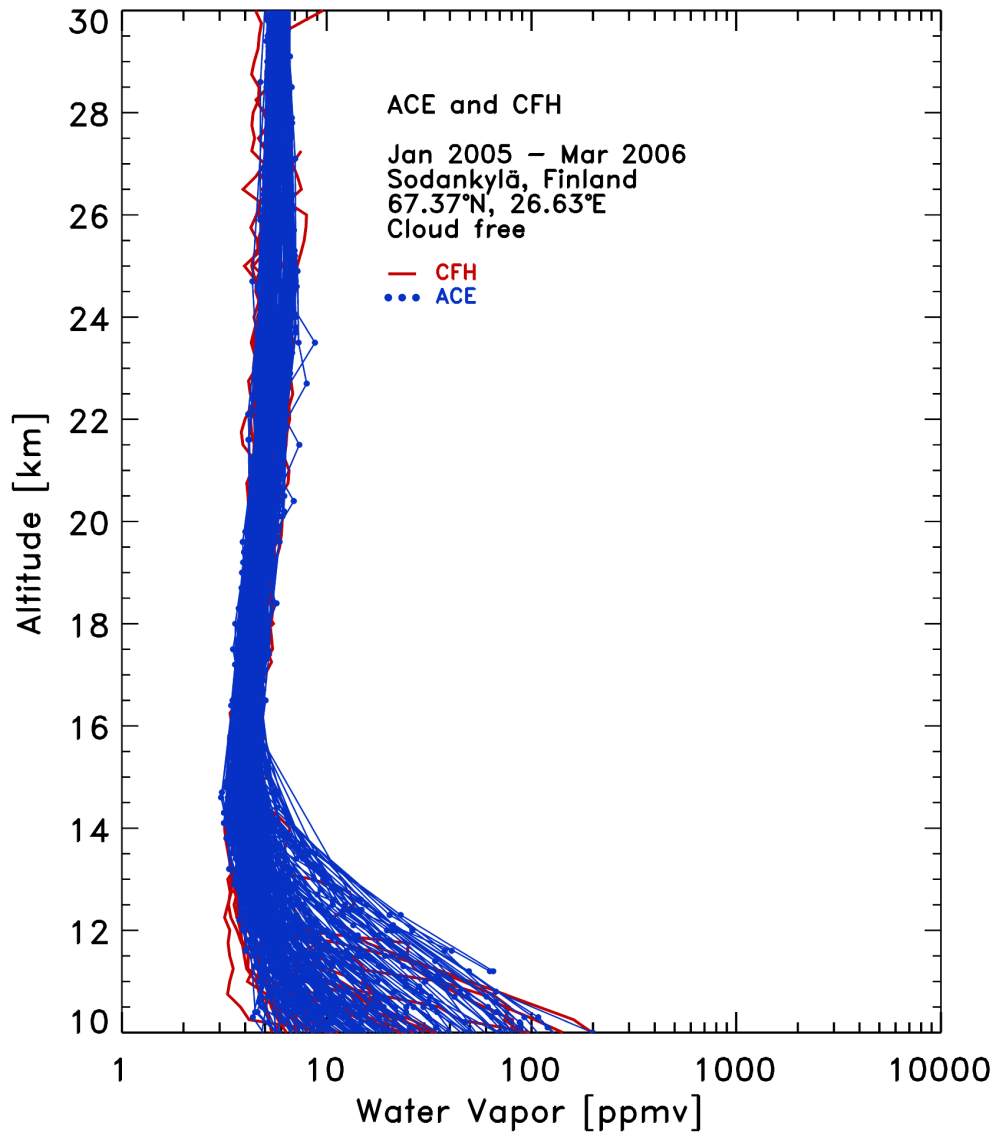

Fig. 20. ACE-FTS (blue) and CFH (red) profiles for the January 2005-March 2006 period, above Sodankylä, Finland (67.37 N, 26.63 E).

\section{ACPD}

$8,4499-4559,2008$

\section{ACE water vapour} validation

M. R. Carleer et al.

Title Page

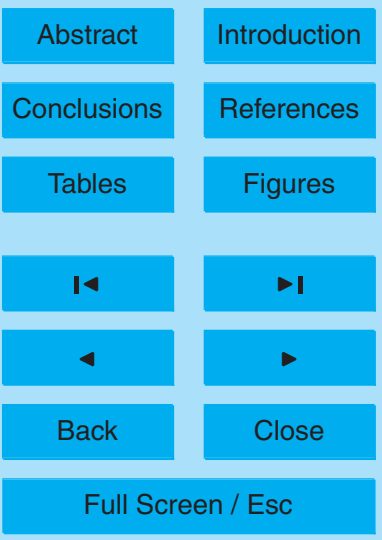

Printer-friendly Version

Interactive Discussion 


\section{ACPD}

8, 4499-4559, 2008

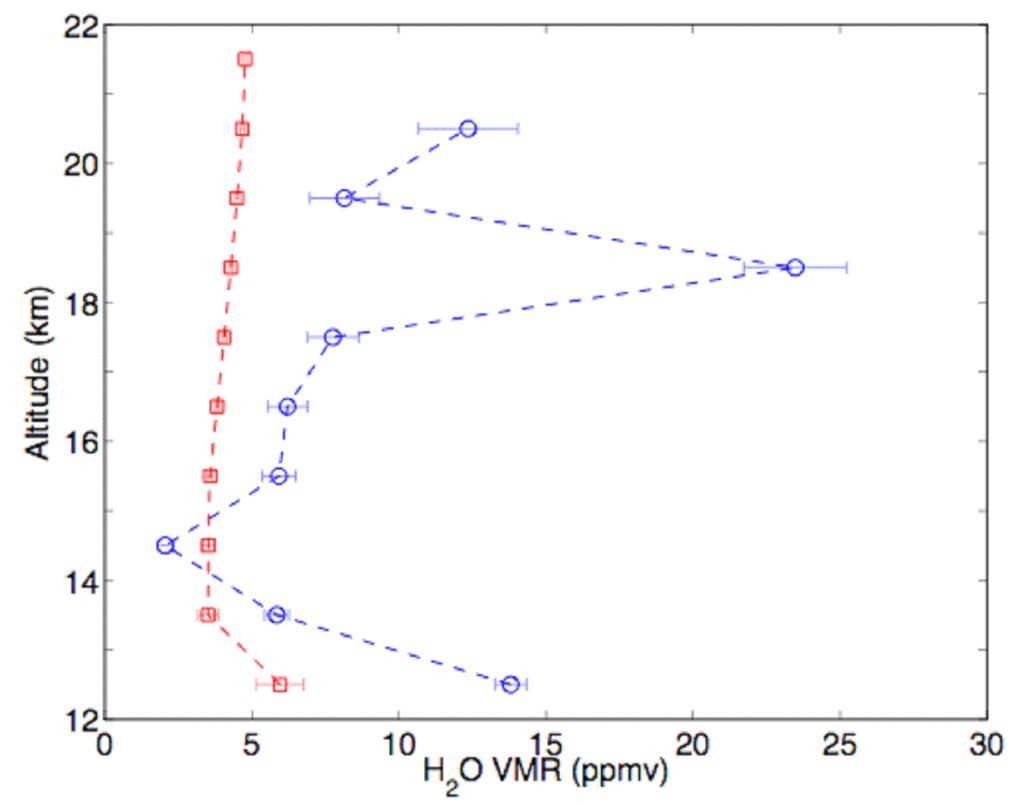

\section{ACE water vapour} validation

M. R. Carleer et al.

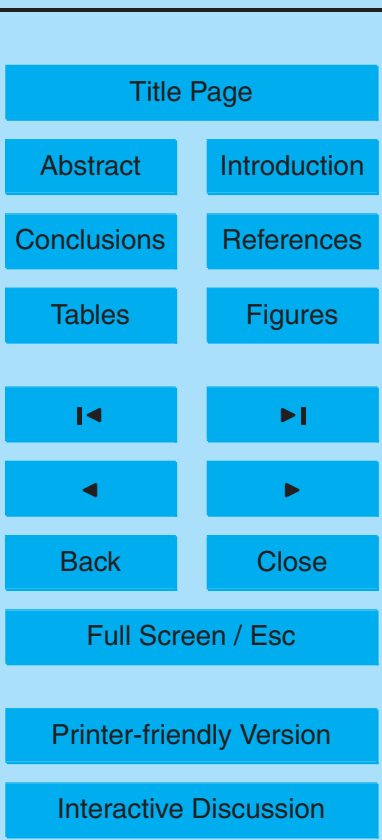

Fig. 21. PCL (blue) and ACE-FTS (red) profiles recorded on 30 June 2005. The horizontal lines are the respective errors on the measurements. For this coincidence ACE-FTS did not retrieve water vapour below $12 \mathrm{~km}$. 


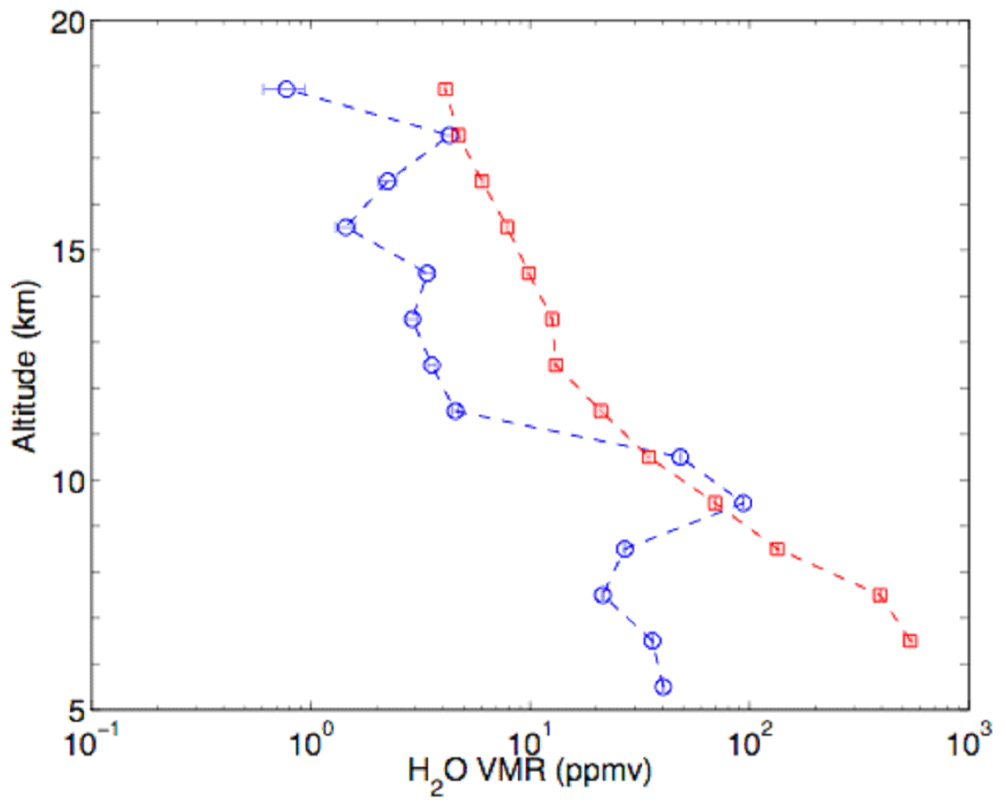

ACPD

8, 4499-4559, 2008

\section{ACE water vapour} validation

M. R. Carleer et al.

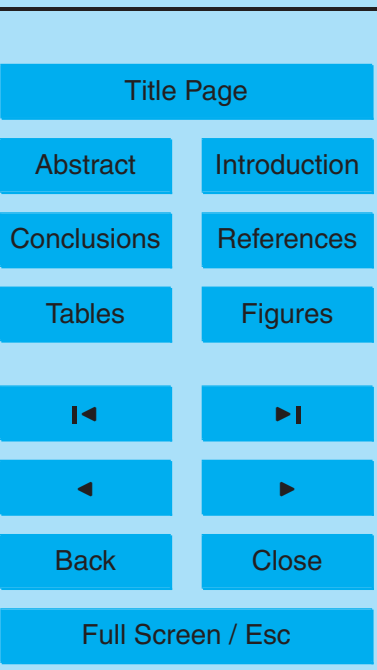

Fig. 22. Same as Fig. 21 on 1 September 2005.

Printer-friendly Version

Interactive Discussion 


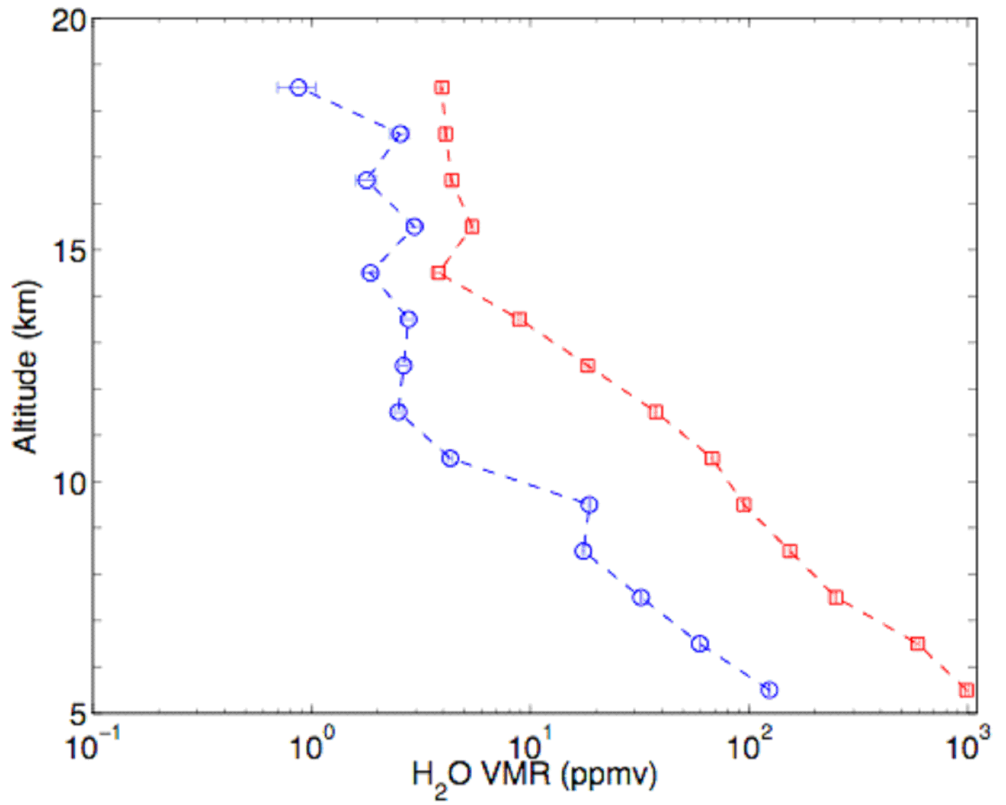

\section{ACE water vapour} validation

M. R. Carleer et al.

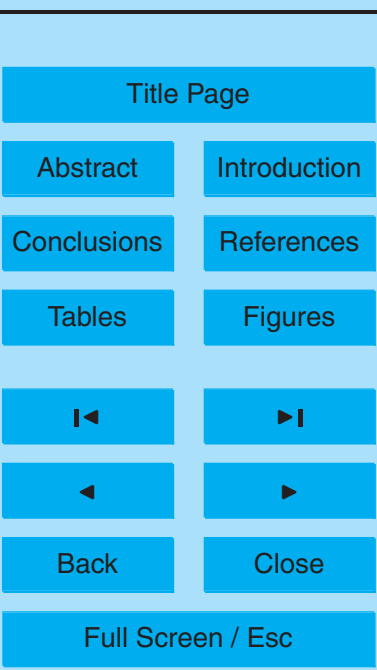

Fig. 23. Same as Fig. 21 on 2 September 2005.

Printer-friendly Version

Interactive Discussion 


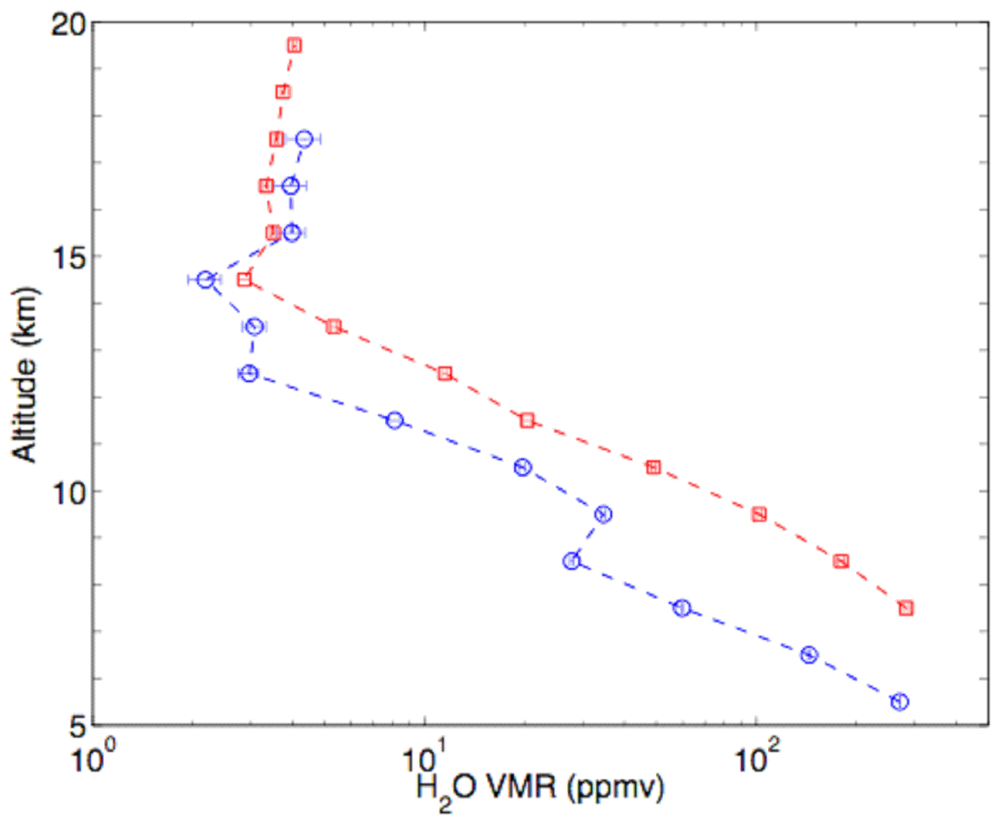

8, 4499-4559, 2008

\section{ACE water vapour validation}

M. R. Carleer et al.

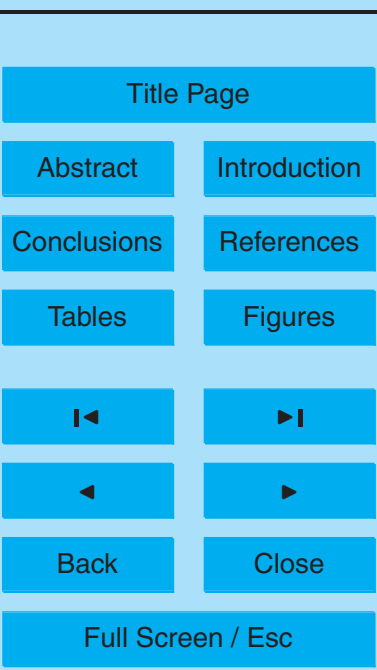

Fig. 24. Same as Fig. 21 on 5 May 2006. 


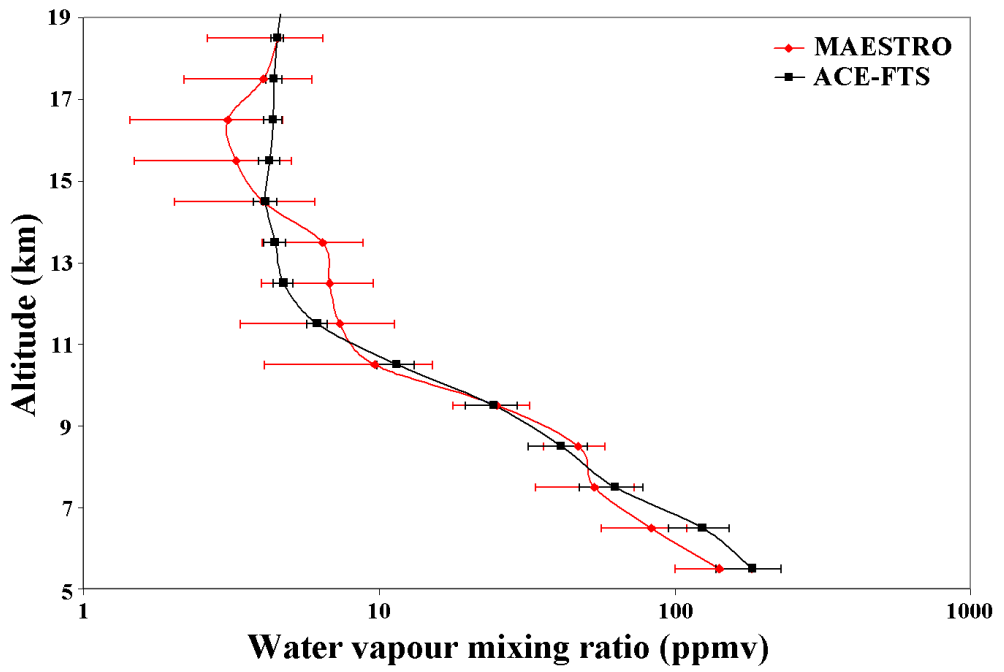

Fig. 25. Comparison of the ACE-MAESTRO (red) and ACE-FTS (black) median profiles for the latitudinal band 70-75 degrees north in October 2005 (autumn). The horizontal lines are the 1-sigma variability on the VMR at the different altitudes.

\section{ACPD}

$8,4499-4559,2008$

\section{ACE water vapour} validation

M. R. Carleer et al.

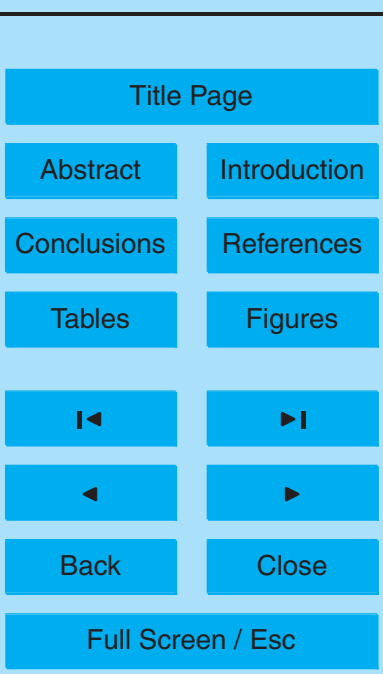

Printer-friendly Version

Interactive Discussion 


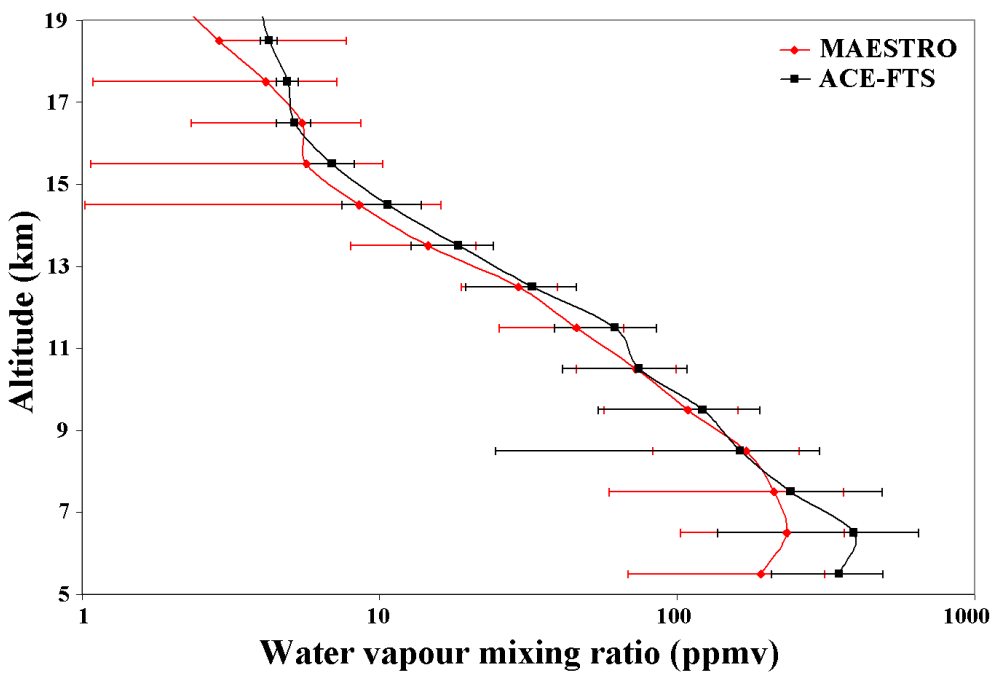

8, 4499-4559, 2008

ACE water vapour validation

M. R. Carleer et al.

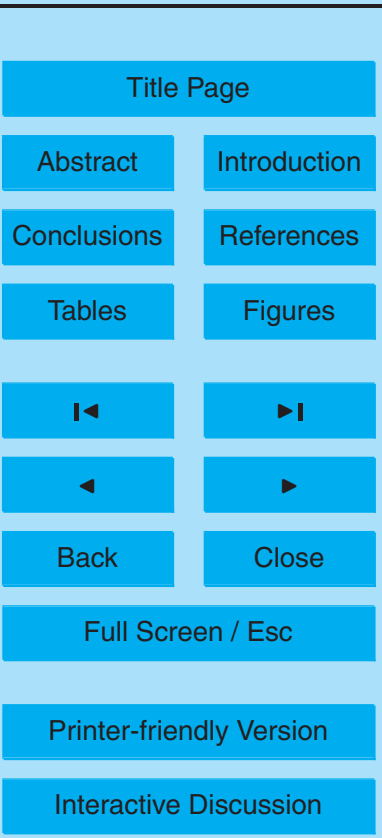




\section{ACPD}

8, 4499-4559, 2008

\section{ACE water vapour validation}

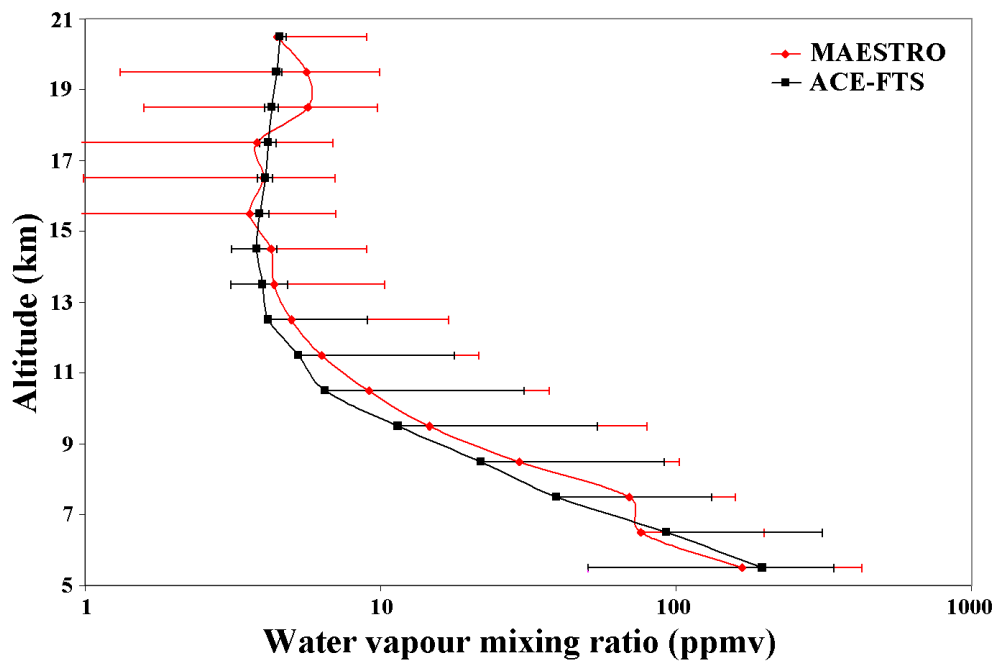

M. R. Carleer et al.

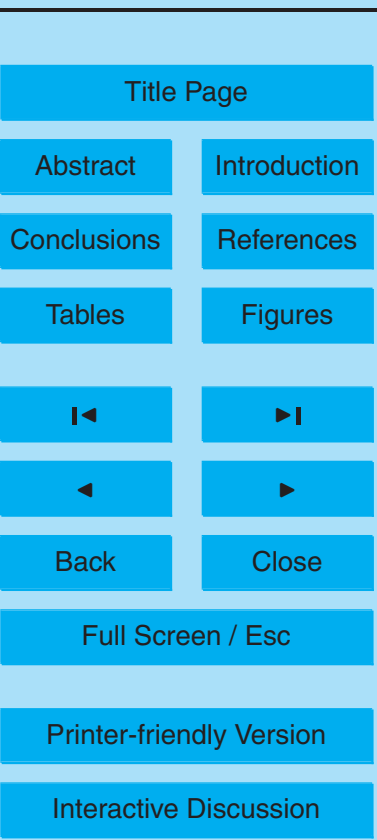




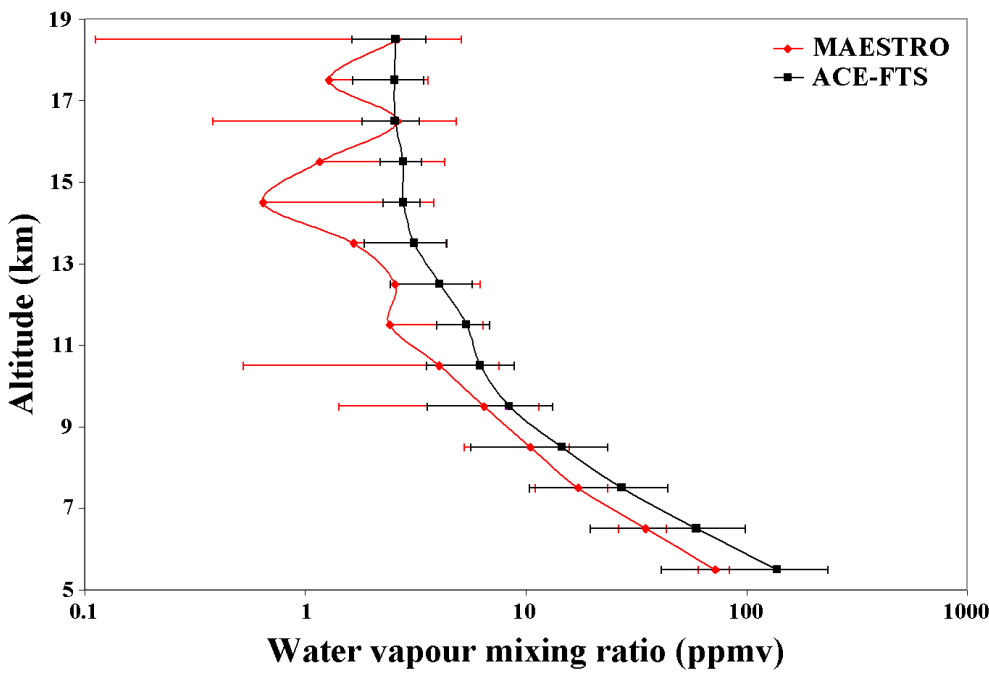

ACPD

8, 4499-4559, 2008

ACE water vapour validation

M. R. Carleer et al.

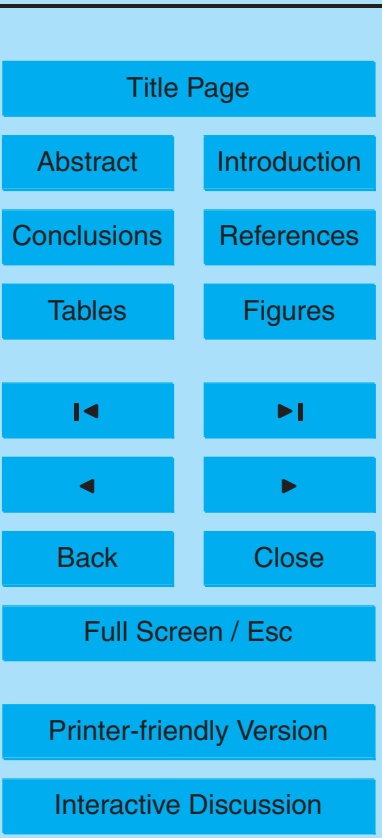

